

\section{ALBERT R. MANN \\ LIBRARY}

AT

CORNELL UNIVERSITY

THE GIFT OF

Isabe 1 Zucker

class ' 26 


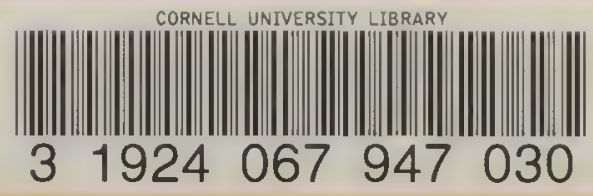

DATE DUE

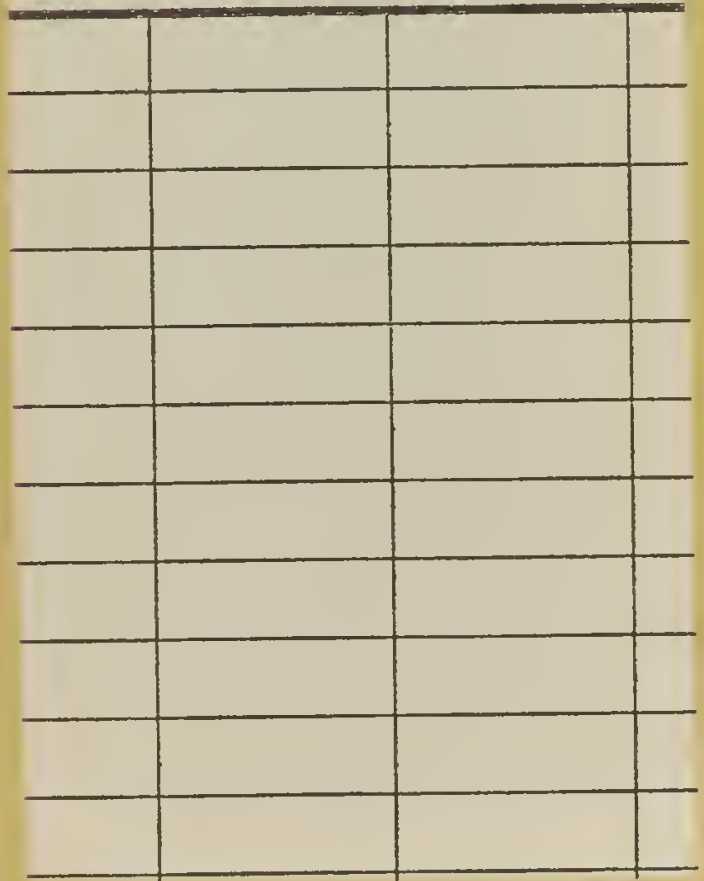




$$
12+
$$





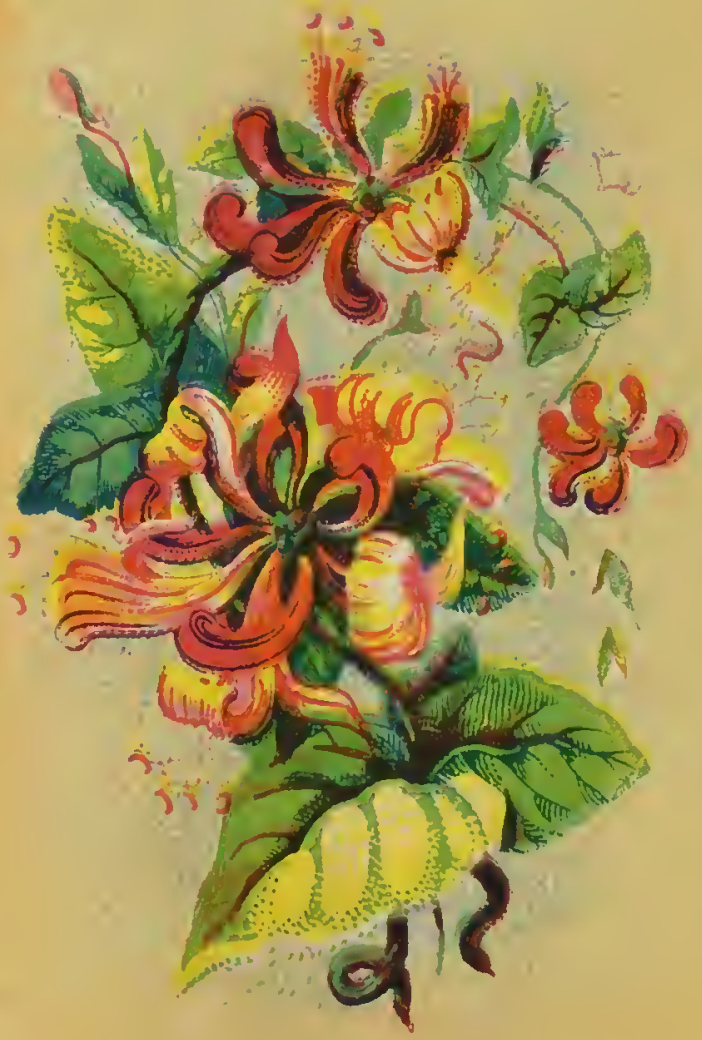




\section{CUPID'S BASKET :}

OR THE

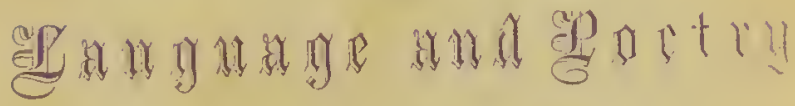

OF

\section{FLOWUES.}

Cogantly rllustrated.

NEW YO K :

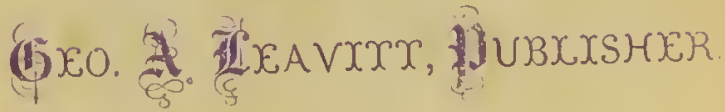




$$
\begin{aligned}
& \text { VAULT } \\
& \text { UNDER } \\
& \text { PN } \\
& 6110 \\
& \text { FG } \\
& \text { C } 97
\end{aligned}
$$




$$
\text { - IEHAC'L. }
$$

"I love God, I love little children, I love the flowers," said a Persian, in vindication of his character as a true poet. Very few, in any time, possessing the "vision and the faculty divine," have failed to give such evilence of inspiration. In cottage and in palace, in every country, and in every age, flowers have been teachers and companions of the gentle and kind hearted; the truest language of love, the liveliest symbols of all holy thoughts and feelings.

This little volume contains some of the most beautiful proms which, from old Chaucer's time, has been written in our language about flowers. It is itself a "garden of poesies," which will not be unwelcome to any who love either song or nature. 



\section{CONTENTS}

Hymn to the fiowers

The wreath

The use of flowers

Flowers sent during illness

The sensitive plant

To a bunch of flowers

To the small celandine -

The ivy

The violet

To the painted columbine

The cypress wreath

The faded flowers

To the rose

Bring flowers -

Transplanted flowers

Rlessed be God for flowers

PAQ

$-11$

14

$-17$

19

- 21)

33

$-35$

37

$-38$

30

$-40$ 42

$-43$ 44

$-40$ 47

To the bramble flower _ _ _ _ _ _ $\quad-49$

Children of the sun's first glancing - - $\quad 50$

Language of thowers

The star and the water lily

Flowers for the heart

The amaranth

The wall-flower

The last rose of summer

The rhodora

The evening primrose

The winter nosegay

The almoud tree 
The lily -

The learygold

The lily -

Cupid and the dial -

The closed conrolvulus -

Human flowers

The dying boy to the sloe blossom

Songs and chorus of the flowers

The narcissus

On receiving a branch of mazereon -

The little red rose

The roice of the flowers

Wild nowers

Cupid inspiring plants with love

The alpine violet

To a daisy -

The ivy song

Daffodils

Adonis' couch

Flower fantasies

Sonnet

The flower dial

Spring nowers -

Bowing adorers

Fragment

To a mountain daisy

The broken flower

To the sumflower

The rose and the gauntlet

The rose

Heart's ease

The moss rose

The hyacinth

Flowers for the grave

at

- 76

80

- 82

83

- 91

92

- 95

97

$\begin{array}{r}-98 \\ \hline\end{array}$

99

- 100

102

$-103$

105

- 108 103

$-110$ 111

- 112

112

- 115

116

- 117

119

- 120

121

- 122 123 
Tre queen of the garden

The cowslip -

To the round-leafed suudew _ _ . $\quad 127$

A cypress leaf

Wild flowers

The jasmine

To primroses -

The daisy

The married compared to the young rose

The lily

The narcissus

A song of the rose -

The rose

The captive and the flowers -

Eragment

The violet -

I send the lilies given to me

liaded flowers

To daffodils

White roses -

The furze

Night blooming flowers

The flower garden

The fragrant air flower

The Alpine flowers

The mistlctoo

To the primrose

The violet -

Faded flowers -

The roses

To the snow drop

To the jessamine

$\mathrm{On}$ a faded violet

Dıพn, gentle flower - 
The lily and the rose -

The lily and the roa -

The violet

The dying girl and flowers

The nightshade

'The lay of the rose

Einblems of flowers -

The orange bough

To the nareissus

The harebell

Sweet lavender

The half-blown rose

To the daisy -

Lore's wreath -

Toa crocus -

Arrangements of a bouquet

On planting a tulip -

To blossoms -

A comparison

The early primrose

The holly

The narcissus

Anacreon to the rose

Decision of the flower

The snow-drop -

Daffodils -

The shepherd to the flowers

Heart's case

The scarlet geranium

The heliotrope -

Amour of the rose -

The forget-me-not

Field leaves -

The Indian jasmine fower

The evening primiose

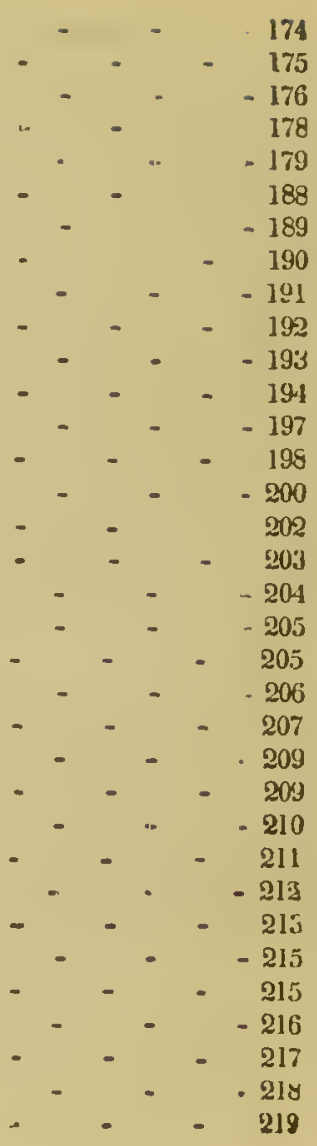


CONTRNTS.

To g.l early primrose -

The rose-bud

'The garland

The field-flowers

To the snow-drop

Cowslips

Heart's ease

To the sweet-brier

A mother's dirge over her child 'The rose

Go to the forest shade -

To a jasmine trec -

April flowers

Flowers

'The orchis

The daisy in India

The primrose of the rock

The rose

'The riolet

Field flowers

In eastern Jands -

The honey suckle

To a snow-drop -

To the passion flomer

'I he lily of the valley

The flower garden

The Language of Flowerg,

- 243 245

- 240

- 257

- 258

. -5

- al

$-20.3$ 256

- 207 



\section{잘ㄹ}

\section{POETRY OF FLOWERS.}

\section{HYMN TO THE FLOWERS.}

\section{BY HORACE SMITH.}

DAY-STARS! that ope your eyes with men, th twinkle

From rainbow galaxies of earth's creation, And dew-drops on her holy altars sprinkle As a libation.

Ye matin worshippers! who bending owly Before the uprisen sun, God's lidless eye? Throw from your chalices a sweet and holy Incense on high.

Ye bright Mosaics! that with storied beauty The floor of nature's temple tesselate With numerous emblems of instructive duty, Your forms create. 
Neath cloistered boughs, each floral bell ths swingeth,

And tolls its perfume on the passing air,

Makes sabbat'. in the ficlds, and ever ringeth

A call to prayer.

Not to the domes where crumbling arch and column

Attest the feebleness of mortal hand,

But to that fane, most catlolic and solemn,

Which God hath planned.

To that cathedral, boundless as our wonder,

Whose quenchless lamps the sun and moon supply ;

Its choir the winds and waves-its organ thunder-

Its dome the sky.

There as in solitude and shade I wander,

Through the green aisles, or stretched upon the sod,

Awed by the silence, reverently ponder The ways of God.

Your voiceless lips, O flowers ! arc living preach. ers,

Each cup a pulpit, and each leaf a book Supplying to my fancy numerous teachers From loncliest nook. 
Foral apostles! that in dewy splendour, "Weep without woe, and blush without a crime,"

O may I deeply learn, and ne'er surrender Your lore sublime!

"Thou wert not, Solonion! in all thy glury, Arrayed," the lilies cry, "in robes like our ; How vain your grandeur! ah, how transitory, Are human flowers!"

in the sweet scented pictures, heavenly Artist!

With which thou paintest nature's wide-spread hall,

What a delightful lesson thou impartest Of love to all !

Not useless are yc, flowers! though made for pleasure,

Blooming o'er field and wave by day and night, From every source your sanction bids me treasure Harmless delight.

Ephemeral sages! what instructors hoary For such a world of thought could furnish scepe I Each fading calyx a memento mori, Yet fount of hope.

Posthumous glories! angel-like collection! Upraised from seed or bulb interred in earth, 
$\mathrm{Xe}$ are to me a type of resurrection, A sccond birth.

Were I, O God! in churchless lands remaining،

Far from all voice of teachers or divines,

My sout would find in flowers of thy ordaining, Priests, sermons, slurines!

\section{$\longrightarrow$ \\ THE WREATH.}

TO A FRIEND ON HER BIRTIIDAY.

BY WILLIAM PETERS.

LET others sing the rich, the great, The victor's palms, the monarch's state,

A purer joy be mine-

To greet the excellent of earth, To call down blessings on thy worth, And, for the hour that gave thee birth, Life's choicest flowers entwine.

And lo! where sunling from above (Mcet helpmate in the work of love)

O'er opening hill and lawn, With flowerets of a thousand dyes, Wit.'. all that's sweet of earth and skies, Soft brea'hes the vernal dawn. 


\section{THE POETRY OF FLOWERS.}

Come! from her stores we'll cull the bes.

Thy bosom to adorn;

Each leaf in livelier verdure dxest, Each blossom balmier than the rest,

Each rose without a thorn;

Fleet tints, that with the rainbow died, Brief flowers, that withered in thoir pride. Shall, blushing into light, awake And kindlier bloom, for thy dear salse.

And first-though oft, alas! condemrad,

Like merit, to the shade-

The Primrose meek, with dews begemand,

Shall sparkle in the braid:

And there, as sisters, side by side,

(Genius with modesty allied,)

The Pink's bright red, the Violet's blue.

In blended rays, shall greet our view,

Each lovelier for the other's hue.

How soft yon Jasmine's sunlit glow, How chaste yon Lily's robe of snow,

With Myrtle green inwove,

Types, dearest, of thyself and me-

of thy mild grace and purity,

And my unchanging love,

Of grace and purity, like thine, And love, undying love, like mine. 
In fancifully plumed array: As ever cloud at set of day,

All azure, vermil, silver-gray

And showering thick perfume, See! how the Lilac's clustered spray

Has kindled into bloom,

Radiant, as Joy, o'er troubles past,

And whispering, 'Spring is come at last!"

Blest Flowers! Tnere breathes not one unfraught

With lessons sweet and new ;

The Rose, in 'Taste's own garden wrought;

The Pansy, nurse of tender thought;

The Wall-flower, tried and true;

The purple Heath, so lone and fair,

1O, how unlike the world's vain glare!)

'The Daisy, so contently gay,

Opening her eyelids with the day;

The Gorse-bloom, never sad or sere,

But golden-bright,

As gems of night,

And fresh and fragrant, all the year ;

Each leaf, each bud, of classic lore,

Oak, Hyacinth, and Floramore ;

The Cowslip, graceful ir her woe;

'The Hawthorn's smile, the Poppy's glow,

This ripe with balm for present sorrow,

And that, with raptures for to-morrow. 
The flowers are culled; and each lithe stem

IVith Woodbine band we braid-

With Woodbine, type of Life's best gem,

Of 'Truth, that will not fade:

'The Wreath is wove; do Thou, blest Power,

That brood'st o'er lenflet, fruit, and flower,

Embalm it with thy love ;

O make it such as angels wear,

Pure, bright, as deck'd earth's first-born pair,

Whilst, free in Eden's grove,

From herb and plant they brushed the dew, Anv uether sin nor sorrow knew.

\section{THE USE OF FLOWERS.}

\section{BY MARY HOWITT.}

GoD might have bade the earth bring forte

Enough for great and small, The oak-tree and the cedar-tree,

Without a flower at all.

He might have made enough, enough,

For every want of ours ;

For luxury, medicine, and toil,

And yet have made no flowers.

The ore withn the mountain-mue

Requireth none to grow, 
Nor doth it need the lotus flower To make the river flow.

The clouds might give abundant raur, The nightly dews might fall, And the herb that keepeth life in mar Might yet have drun!s them all.

Then, wherefnre, wherefore were thoy rnat All dyed with rainbow light; All fashion'd with supremest grace: Up-springing day and night;

Springing in valleys green and low, And on the mountains high, And in the silent wilderness, Where no man passes by?

Our outward life requires them notThen wherefore had they birth ? To minister delight to man, To beautify the earth;

To coinfort man-to whisper hope Whene'er his faith is dim ; For who so careth for the flowera. Will murh more care for hirn: 


\section{FLOWERS :}

SENT ME DURING ILLNESS.

BY RICHARD H. DANA.

I loved you ever, gentle flowers,

And made you playmates of my youth ;

The while your spirit stole

In secret to my soul,

Io shed a softness through my ripening powere, And lead the thonghtful mind to deepest trutls.

And now, when wearincss and pain

Had cast you almost from my breast,

With each a smiling face,

In all your simple gracc,

You comc once more to take me back again From pain to ease, from weariness to rest.

Kind visitants! throngh my sick room You seem to breathe an air of health,

And with your looks of joy

To wake again the boy,

And to the pallid chcck restore its bloom, And o'er the desert mind pour boundless wealth

And whence ye came, by brimming stream. 'Neath ruetling lraves, with birds within. 
Again 1 musing tread-

Forgot my restless bed,

And long, sick hours.-Too short the blessed dream !

I woke to pain!-to hear the city's din!

But time nor pain shall ever steal

Or youth or beasty from my mind,

And blessings on ye, Flowers .

Though few with me jour hours,

The youth and beauty, and the hcart to feel,

In her who sent you, ye will leave behind!

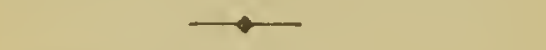

THE SENSITIVE PLANT.

BY SHELLY.

PART I.

A Sensitive plant in a garden grew,

And the young winds fed it witl silver dew;

And it open'd its fan-like leaves to the light,

And closed them beneath the kisses of night.

And the spring arose on the garden fair, Lite the spirit of love, felt every where ! And each flower and herb on earth's dark breast Rose from the dreams of its wintry rest. 
The snow-drop, and then the violet, Arose from the ground with warm rain wet; And their breath was mix'd with fresh odour, sen' From the turf, like the voice to the instrument.

Then the pied wind-flowers, and the tulip tall, And narcissi, the fairest among them allWho gaze on their eyes in the stream's recess, Till they die of their own dear loveliness!

And the naiad-like lily of the vale, Whom youth makes so fair, and passion so palo. That the light of its tremulous bells is seen Through their pavilioss of tender green;

And the hyacinth, purple, and white, and blue, Which flung from its bells a sweet peal anew Of music so delicate, soft, and intense, It was felt like an odour within the sense;

And the rose like a nymph to the bath addrest, Which unveil'd the depth of her glowing breast, Till, fold after fold, to the fainting air The soul of her beauty and love lay bare;

And the wand-like lily, which lifted up, As a Mænad, its moonlight-colour'd cup, Till the fiery star, which is its eye, Fazed through olear dew on the tender sky. 
And the jessamine faint, and the sweet tuberow, The sweetest flower for scent that blows! And all rare blossoms, from every clime, Grew in that garden in perfect prime.

And on the stream whose inconstant bosom Was prankt, under boughs of embowering tlos. som,

With golden and green light, and starting through Their heaven of many a tangled nue,

Broad water-lilies lay tremulously, And starry river-buds glimmer'd by, And around them the soft stream did glide ard dance

With a motion of sweet sound and radiance.

And the sinuons paths of lawn and moss, Which led through the garden along and acrossSome open at once to the sun and the breeze, Some lost among bowers of blossoming trees-

Were all paved with daisies and delicate bells As fair as the fabalous asphodels, And Howerets winich drooping as dlay droop'd toa Fell into pavilıns white, purple, and blue, To roof the grow-worm from the evening dew.

And from this undefiled paradise The flowurs (as in infant's arvakening eyes 
Smile on its mothcr, whose singing sweet Can first lull, and at last must awaken it),

Whon heaven's blithe winds had unfolded them As mine-lamps enkindlc a hidden gem, Shone smiling to heaven, and every one Shared joy in the light of the gentle sun;

For each one was interpenetrated

With the light and the odour its ncighbour shed, Like young lovers whom youth and love make dear,

Wrapp'd and fill'd by thcir mutual atmosphere.

But the sensitive plant, which could give small fruit

Of the love which it felt from the leaf to the root, Received morc than all, it loved more than ever, Where none wanted but it, could belong to the giver.

For the sensitive plant has no bright flower; Radiance and odour are not its dower; It loves, even like I,ove; its decp heart ig full; It desires what it has not, the beautiful!

The light winds, which from unsustaining wings, Shed the music of many murmurings; 'T'he beams which dart from many a star of the flowers whose hucs they bear afar: 
The plumed insects swift and free, Like golden boats on a sunny sea, Laden with light and odour, which pass Over the glean of the living grass;

The unseen clouds of the dew, which lie Like fire in the flowers till the sun rides high, Then wander like spirits among the spheres. Each eloud faint with the fragrance it bears;

The quivering vapours of dim noon-tide, Which like a sen o'er the warm earth glide, In which every socnd, and odour, and beam. Movc, as reeds in a single stream;

Each and all like ministering angels were For the sensitive plant sweet joy to bear, Whilst the lagging hours of the day went by' Like windless elouds o'er a tender sky.

And when evening deseended from heaven a'sove, And the earth was all rest, and the air was all love,

And delight, though less bright, was far more deep,

And the day's veil fell from the world of sleep;

And the beasts and the birds, and the insecte were drown'd

In an ocean of dreams wi hout a sound; 
Whose waves rever mark. though they ever impress

The light sand which paves it, eonseiousness;

Only overhead the sweet nightingale Ever sang more sweet as the day might fail, And snatehes of its Elysian ehant

Were mix'd with the dreams of the sensitive plant ;)

The seneitive plant was the earliest Up.gathor'd into the bosom of rest; A sweet child weary of its delight, 'The fentslest and yet the favourite, Cradle twithin the embraee of night.

\section{PART II.}

The was a power in this sweet place, An K.ve in this Eden; a ruling grace Which to the flowers, did they waken or dream, Wos as God is to the starry seheme:

1 lady, the wonder of her kind, 'Nhose form was upborne by a lovely mind, Whieh, dilating, had moulded her mien and mo. tion

aire a sea-1lover unfolicd beneath the oeean, 
'I'enaed the garden from morn to even; ind the meteors of that sublunar heaven, Like the lamps of the air when night walks forth Laugh'd round her footsteps up from the earth!

She had no companion of mortal race, But her tremulous breath and her flushing face, Told, whilst the morn kiss'd the sleep from her eyes,

That her dreams were less slumber than paradise,

As if some bright spirit for her sweet sake Had deserted heaven while the stars were awake, $A s$ if yet around her he lingering were, Though the veil of daylight conceal'd him from her.

Her step seem'd to pity the grass it prest; You might hear, by the heaving of her breast, That the coming and the going of the wind Brought pleasure there, and left passion behind.

And wherever her airy footstep trod, Her trailing hair from the grassy sod Erased its light vestige, with shadowy sweep, Like a sunny storm o'er the dark green deep.

I doubt not the flowers of that garden sweet Rejoiced in the sound of her gentle foet; 
I doubt not they felt the sprrit that came From her glowing fingers through all thair frame.

She sprinkled bright water from the stream On those that were faint with the sunny beam; And out of the cups of the heavy flowers She emptied the rain of the thunder showers.

She lifted their heads with her tender hands, And sustain'd them with rods and osier bands; If the flowers had been her own infants, she Could never have nursed them more tenderly.

And all killing insects and gnawing worms, And things of obscene and unlovely forms, She bore in a basket of Indian woof Into the rough woods far aloof.

In a basket, of grasses and wild flowers full, 'I'he freshest her gentle hands could pull For the poor banish'd insects, whose intent, Although they did ill, was innocent.

But the bee and the beam-like ephemeris, Whose path is the lightning's and soft moths that kiss

The sweet lips or the flowers, ard harm not, did she

Make her attendant angels be. 
And niany an anternatal tomb.

Where butterflies dream of the life to eome, She left elinging round the smooth and dark Edge of the odorous eedar bark.

This fairest ereature from earliest spring Thus moved through the garden ministering, All the sweet season of the summer-tide, And ere the first leaf look'd brown-she died

\section{PART IIL.}

Three days the flowers of the garden fair, Like stars when the noon is awaken'd, were, Or the waves of the Baiæ, ere luminous She floats up through the smoke of Vesuvius.

And on the fourth, the sensitive plant Felt the sound of the funeral ehant, And the steps of the bearers, heavy and slow, And the sobs of the mourners, deep and low.

The weary sound and the heavy breath, And the silent molions of passing death, And the smell, cold, oppressive, and dank, Sent through the pores of the eorfin plank;

The dark grass, and the flowers among the grass, Were bright with tears ns the crowds did pass. 
From their sighs the wind caught a mournful tone, And satc in the pines, and gave groan for groan.

The garden, once fair, bccame cold and foul, Like the corpse of her who had been its soul: Which at first was lovely as if in sleep, Then slowly changed, till it grew a heap 'To make men tremble who never weep.

Swift summer into the autumn flow'd, And frost in the mist of the morning rode, Thougl the noon-day sun look'd clear and bright, Mocking the spoil of the secret night.

'The rose-leaves, like flakes of crimson snow,

Paved the turf and the moss below; The lilies were drooping, and white, and wan, Like the head and the skin of a dying man.

And Indian plants, of scent and hue 'The sweetest that ever were fcd on dew, Leaf after leaf, day by day, Were massed into the common clay.

And the leaves, brown, yellow, and gray and red And white with the whiteness of what is dead, Like troops of ghosts on the dry wind pass'd; 'Their solistling noise made the birds aghast. 
And the gusty winds waked the winged seeds Out of their birth-place of ugly weeds, 'Till they clung round many a sweet flower's stem Which rotted into the earth with them.

The water-blooms under the rivulet Fell from the stalks on which they were set; And the eddies drove them here and there, As the winds did those of the upper air.

Then the rain came down, and the broken stalks Were bent and tangled across the walks; And the leafess net-work of parasite bowers Mass'd into ruin, and all sweet flowers.

Between the time of the wind and the snow, All loathliest weeds began to grow, Whose coarse leaves were splash'd with many speck,

Like the water-snake's belly and the toad's back

The sensitive plant, like one forbid, Wept, and the tears within each lid Of its folded leaves, which together grew, Were changed to a blight of fiozen glue.

For the leavis soon fell, and the branches soon By the heavy axe of the blast were hewn; The sap shrank to the root through every pore, As blood to a heart that will beat no mcre. 
For Winter came: the wind was his whip; One choppy finger was on his lip: He had torn the cataracts from the hills, And they clank'd at his girdle like manacles;

His brcath was a chain which, without a sound, The earth, and the air, and the water bound; He came, fiercely driven in lis chariot throne By the tenfold blasts of the arctic zone.

Then the wceds which were forms of living deatb Fled from the frosts to the earth bencath: Their dccay and sudden flight from frost, Was but like the vanishing of a ghost!

And under the roots of the sensitive plant The moles and the dormice dicd for want; And the birds dropp'd stiff from the frozen air, And were caught in the branches naked and bare.

First there came down a thawing rain, And its dull drops froze on the boughs again, Then therc stcam'd up a freezing dew Which to the drops of the thaw-rain grew;

And a northern whirlwind, wandering about like a wolf that had smelt a dcad child out, Shook the boughs thus laden and heavy and stiff. And snapp'd them off with his rigid griff. 
When winter had gone and spring came back, The sensitive-plant was a leafless wreck; But the mandrakes, and toadstools, and docka and darnels,

Rose like the dead from their buried charnele. CONCLUSION.

Whether the sensitive plant, or that Which within its boughs like a spirit sat, Ere its outward form had known decay, Now felt this change, I cannot say.

Whether that lady's gentle mind, No longer with the form combined, Which scattel'd love, as stars do light, Found sadness where it left delight,

I dare not gucss; but in this life Of error, ignorance, and strife, Where nothing is, but all things seem, And we the shadows of the dream.

It is a modest crecd, and yet Pleasant, if one considcrs it, To own that death itself must be, Like all the rcst, a mockery.

Tha: garden sweet, that lady fair, And all swect shapes and odours there, 


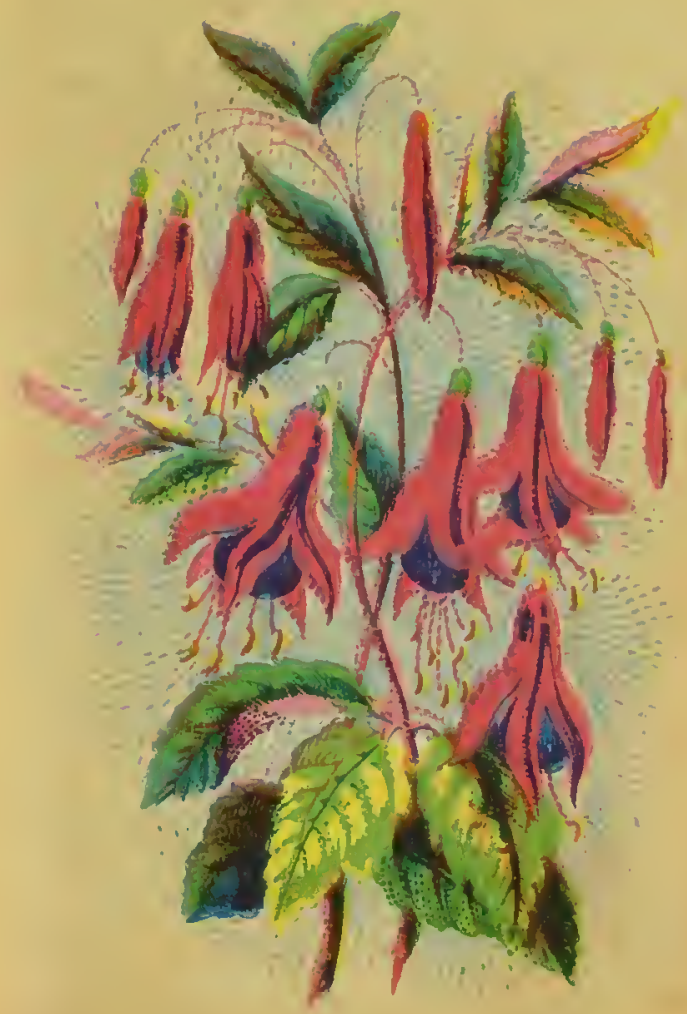



In truth, have never pass'd away: 'Tis we, 'tis ours, are elhanged! not they.

For love, and beauty, and delight, There is no death nor ehange; their might Exceeds our organs, which endure No light, being themselves obscure.

\section{$\rightarrow$ \\ TO A BUNCH OF FLOWERS.}

BY. REV. JAMES F. CLARKE.

LiTTLE firstings of the year! Have you come my room to cheer? You are dry and parched, I think; Stand within this glass and drink; Stand beside me on the table, 'Mong my books-if I am able, I will find a vacant space For your bashfulness and grace; Learned tasks and serious duty Shall be liglitened by your beauty. Pure affection's sweetest token, Clooicest hint of love unspoken, Friendship in your help rejoices, Lttering her mysterious voices. $Y$ ou are gifis the poor nay offerWealth ean find no better proffer : For you tell of tastes refined, Thoughtful heart and spirit kind. 
Gift of gold or jewel dresses Ostentation's thought confesses; Simplest mind this boon may give: Modesty herself receive. For lovely woman you were meant 'I'he just and natural ornament, Sleeping on her bosom fair, Hiding in her raven hair, Or, peeping out mid golden curls. You outshine barbaric pearls; Yct youlead no thought astray, Feed not pride nor vain display, Nor disturb her sisters' rest, Waking envy in their breast. Let the rich, with heart elate, Pile their board with costly plate Richer ornaments are ours, IVe will dress our home with flowere, Yet no terror leed we feel Lest the thief break through to steal. Ye are playthings for the child, Gifts of love for maiden mild, Comfort for the aged eye, For the poor, eheap luxury. Though your life is but a day, Preeious things, dear flowers, you say Telling that the Being good IV ho supplies our daily food, Deems it needful to supply Daily food for heart and eye. 
So, though your life is but a day, We grieve not at your swift decay; $\mathrm{He}$, who smiles in your bright faces, Sends us more to take your places; 'Tis for this ye fade so soon, That he may renew the boon: That kindness often may repeat 'These mute messages so sweet: That Love to plainer speech may get, Conning oft his alphabet;

That beauty may be rain'd from heaven, New with every morn and even, With freshest fragrance sunrise greeting: Therefore are ye, flowers, so fleeting.

\section{TO THE SMALL CELANDINE}

WORDSWORTH.

Pansies, lilies, king-cups, daisies, Let them live upon their praises; Long as there's a sun that sets, Primroses will have their glory; Long as there are violets, They will have a place in story: There's a flower that shall be mino, 'Tis the little Celandine. 
Ere a leaf is on a bush, In the time before the thrush Has a thought about her nest, Thou wilt come with half a call, Spreading out thy glossy breast Like a careless prodigal; 'Telling tales about the sun, When we've little warmth, or non

Comfort have thou of thy merit, Kindly unassuming Spirit! Careless of thy neighbourhood, Thou dost show thy pleasant face On the moor, and in the wood, In the lane; - there's not a plaee. Howsoever mean it be, But 'tis good enough for thee.

IIl befall the yellow flowers, Children of the flaring hours! Butter-cups that will be seen, Whether we will see or no; Others, too, of lofty mien; They have done as worldlings do, Taken praise that should be thines Litıle, humble Celandine!

Prophet of delight and mirtb, Ill requited upon earth; Herald of a mighty band, Of a joyous train ensuing, 
Serving at my heart's command, Tasks that are no tasks renewing,

I will sing, as doth behove, IIynuns in praise of what I love !

\section{$\rightarrow$ \\ THE IVY.}

BARTON.

HAST thou secn, in winter's stormicst day,

I he trunk of a bliglited oak,

Not dead, but sinking in slow decay

Beneath time's resistless stroke,

Round which a luxuriant ivy had grown,

And wreathed it with verdure no ionger its own?

Perchance thou hast secn this siglit, and then, As I at thy years might do,

Pass'd carelessly by, nor turn'd again That scathed wreck to vicw.

But now I can draw from that mouldcring tree Ihoughts which arc soothing and dear to me.

O smile not! nor think it a worthless thing, If it be with instruction fraught;

That which will closcst and longest cling

Is alone worth a serious thought!

should aught be unlovely which thus can shed Grace on the dying, and leaves on the dead? 


\section{THE VIOLE'T.}

\section{FROM THE GERMAN OF GOETHE}

A violet blossom'd on the green, With lowly stem, and bloom unseen :

It was a sweet, low flower.

A shepherd maiden eame that way, With lightsome step and aspect gay,

Came near, came near, Came o'er the green with song.

A h ! thought the violet, might I be 'The fairest flower' on all the lea, Ah ! but for one brief hour ; And might be plucked by that dear mald And gently on her bosom laid, Ah! but, ah! but

A few dear moments long.

Alas! the maiden, as she pass'd, No eye upon the violet east: She crush'd the poor, wee flower; It sank, and dying, heaved no sigh, And if I die, at least I die By her, by her, Reneath her fest I dio. 
THB POETRY OF FLOWERS.

\section{TC 'THE PAINTED COI,UMBINE.}

\section{BY JONES VERY.}

BRIGIT image of the early years

When glow'd my cheek as red as thou,

And life's dark throng of cares and fears Were swift- winged shadows o'er my sunny brow:

'l'hou blusliest from the painter's page,

Robed in the mimic tints of art;

But Nature's hand in youth's green age With fairer hues first traced thee on my heart.

'l'he morning's blush, she made it thine,

The morn's sweet breath, she gave it thee;

And in thy look, my Columbine!

Each fond-remember'd spot she bade me see.

I see the hill's far-gazing head,

Where gay thou noddest in the gale;

I hear light-bounding footsteps tread 'The grassy path that winds along the vale.

I hear the voice of woodland song

Break from each bush and well-known tree, And, on light pinions borne along,

somes back the laugh from c'i! ihood's heart of glee. 
O'il tive dark rock the dashing brook,

itith louk of anger, leaps again, Ana hasiening to each flowery nook, [ts his!..2] voiec is heard far down the glen,

Fair child of art! thy charms aceay,

Touched by the wither'd liand of Time.

And hushed the musie of that day,

When my voice mingled with the streamlet's chime;

But on my lieart thy eheek of bloom

Shall live when Nature's smilc has fled;

And rich with memory's sweet perfume, Shall o'er her grave thy tribute incense shed.

T'here shalt thou live and wake the glee Tliat echoed on thy native hill; And when, loved flower! I think of thee, My infant feet will seem to seek the still.

\section{THE CYPRESS WREATH.}

BY SIR W. SCOTT.

O LADY, ewinc no wreath for $\mathrm{mc}$, Or twine it of the cypress-trce : Too lively glow the lilies light, 'The varnish'd holly's all too t igit, 
I'he May-flower and the eglantine May shade a brow less sad than mine; But, lady, weave no wreath for me; Or weave it of the cypress-tree.

Let dimpled Mirth his temples twine With tendrils of the laughing vine; The manly oak, the pensive yew, To patriot and to sage be due; The myrtle bough bids lovers live, But that Matilda will not give; 'Then, lady, twine no wreath for me, Or twine it of the cypress-tree.

Let merry England proudly rear Her blended roses, bought so dear, Let Albin bind her bonnet blue With heath and liarebell dipp'd in dew ; On favour'd Erin's erest be seen The flower she loves of emerald greenBut, lady, twine no wreath for me, Or twine it of the cypress-trec.

Strike the wild harp, while maids prepare 'The ivy meet for minstrel's hair; And while his erown of laurel leaves With bloody hand the victor weaves, Let the loud trump his triumph tell; But when you hear the passing bell, 'Then, lady, twine a wreath for me, And twine it of tho cypress-tise. 
Yes! twine for me the cypress bough;

But, O Matilda, twine not nowStay till a few brief months are pasi, And I have look'd and loved my last ! When villagers my shroud bestrew With pansies, rosemary, and rue,Then, lady, weave a wreatl for me. And weave it of the eypress-tree.

\section{THE FADED FLOWERS.}

BY. REV. WALTER COLTON, U. S. N.

YO THE LADY WHO PRESENTED THE AUTHOR WITH A CLUSTER OF FADED FLOWERS.

TiIEsE faded flowers a softer grief Than blooming ones beget; More tender now on each pale leaf The tints that linger yet: For all the charms, that eheer'd the past, Hang round these hues that fade the last. 'The morn they had their fragrant birth, The wild shrubs where they grew, The bee that in its matin mirth Hung over their pearls of dew, Must share alike the floweret's lot, And lie with frailer things forgot. 
Not thus with thee in that dim day,

When, like the breath of flowers, Thy spirit leaves its vase of elay,

For love in those lone hours, Shall treasure up thy gențle worth, And warn remembrance eall it forth,

And in a brighter, purer sphere,

Beyond the sunless tombThe virtues, that have eharmed us here,

In fadeless life shall bloom;

And win from faith the fervid prayer, To meet thy sainted spirit there.

\section{$\rightarrow$ \\ TO THE ROSE. \\ BY C. P. CRAYCH.}

DEAR flower of heaven and love! Thou glorious thing

That lookest out the garden nooks among: Rose, that art ever fair and ever young; Was it some angel or invisible wing Hovered around thy fragrant sleep. in fling His glowing mantli? of warm sunset hues O'er thy unfolding petals, wet with dews Such as the flower-fays to Titania bring? 0 flower of thousand memories and dreams, "l'hat take the heart with faintness, while we gaze 
On the rich depths of thy inwoven maze; From the green banks of Eden's blessed streamı I dream'd thee brought, of brighter days to tell, Long pass'd, but promised yet with us to dwell.

\section{BRING FLOWERS.}

MRS. HEMANS.

Brivg flowers, young flowers, for the festal board, To wreathe the cup ere the wine is pour'd; Bring flowers! they are springing in wood and vale,

'Their breath floats out on the southern gale, And the touch of the sunbeam hath waked the rose,

To deek the hall where the bright wine flows.

Bring flowers to strew in the conqueror's pathHe hath shaken thrones with his stormy wrath ' He comes with the spoils of nations baek, The vines he crush'd in his chariot's track, The turf looks red where he won the dayBring flowers to die in the conqueror's way :

Bring flowers to the eaptive's lonely cell, 'They have tales of the joyous woods to tell; Of the free blue streams, and the glowing sky, And the bright world shut from his languid eye: 
They will bear him a thought of the sunny hours, And a dream of his youth-bring him flowers, wild flowers.

Bring flowers, fresh flowers, for the bride to wear!

They were born to blush in her shining hair. She is leaving the lome of her childhood's mirth, She hath bid farewell to her father's hearth.

I Ior place is now by another's side-

Bring flowers for the locks ot the fair young bride.

Bring flowers, pale flowers, o'er the bier to shed, A crown for the brow of the early dead!

For this through its leaves hath the wild rose burst,

For this in the roods was the violet nursed! Though they smile in vain for what once was ours, 'They are love's last gift-bring ye flowers, pale flowers :-

Bring flowers to the shrine where we kneel in prayer,

'They are Nature's offering, their place is there?

They speak of hope to the fainting heart,

With a voice of promise they come and part, They sleep in dust through the wintry hours, They break forth in glory-bring flowers, bright flowers ! 
THE POETRS OF FLUIVERS.

\title{
TRANSPLANTED FLOWERS.
}

\author{
BY E. ELLIOTT.
}

$Y_{E}$ living gems of cold and fragrant fire! Die ye for ever, when ye die, ye flowers? Take ye, when in your beauty ye expire, An everlasting farewell of your bowers? No more to listen for the wooing air, And song-brought morn, the eloud.tinged wood lands o'er!

No more to June's soft lip your brensts to bare, And drink fond evening's dewy breath no more Soon fades the sweetest, first the fairest dies, For frail and fair are sisters; but the heart, Fill'd with deep love, death's power to kill denies And sobs e'en o'er the dead, "We cannol part!" Have I not seen thee, Wild Rose, in my dreanis! Like a pure spirit-beauteous as the skies, When the elear blue is brighest, and the streams Dance down the hills, refleeting the rich dyes Of morning elouds, and eistus woodbine-iwinedDidst thou not wake me from a dream of death? Yea, and thy voice was sweeter than the wind When it inhales the love-siek violet's breath. Bending it down with kisses, where the beo llums over golden gorse, and sunny broom, Soul if the $R$ ise! What saidst thou then to me! 
"We meet," thou said'st, "though sever'd by the tomb:

L.o. brother, this is heav'n! And thus the jus! shall bloom."

\section{BLESSED IIE GOD FOR FLOWERS.}

uggested by seeing my youngest child asleep, with Wild Flowers grasped in its hand.

BY IIRS. CHARLES TIITLEY.

BuEssen be God for flowers!

For the bright, gentle, holy thoughts, that breatho Srom out their odorous beauty, like a wreath

Of sunshine on life's hours!

Lightly upon thine eye

IIath fallen the noon-tide sleep, my joyous bird : And through thy parted lips the breath, scarco heard,

Comes like a summer sigh.

One rosy hand is tluown Beneath thy rosier cheek : the other holds A group of sweet field-flowers, whose bloom uniolds

A freshness like thine uwn 
Around the fragrant prize, With cager grasp thy little fingers close : What are the dreams that haunt thy soft repose What radiance greets thine eyes?

For thou art smiling still; Art thou yet wanderng in the quiet woods, Plucking th' expanded cups and bursting buds, At thine whetter'd will?

Or does some prophel voice Murmuring amidst thy dreams, instructive say, "Prize well these flowers, for thou, beyond to-day,

Shalt in their spells rejoice !"

Yes! thou wilt learn their power, IVhen, cherish'd not as now, thou stand'st alone, Compass'd by sweetly saddening memories. thrown

Round thee by leaf or flower!

"T'will come! as seasons come, 'I'he empire of the flowers, when these shall raiss Round thee once more the forms of other davs Warm with the light of horne !

Shapes thou no more may'st sce; The housclıold hearth, the heart-enlisted prayer 


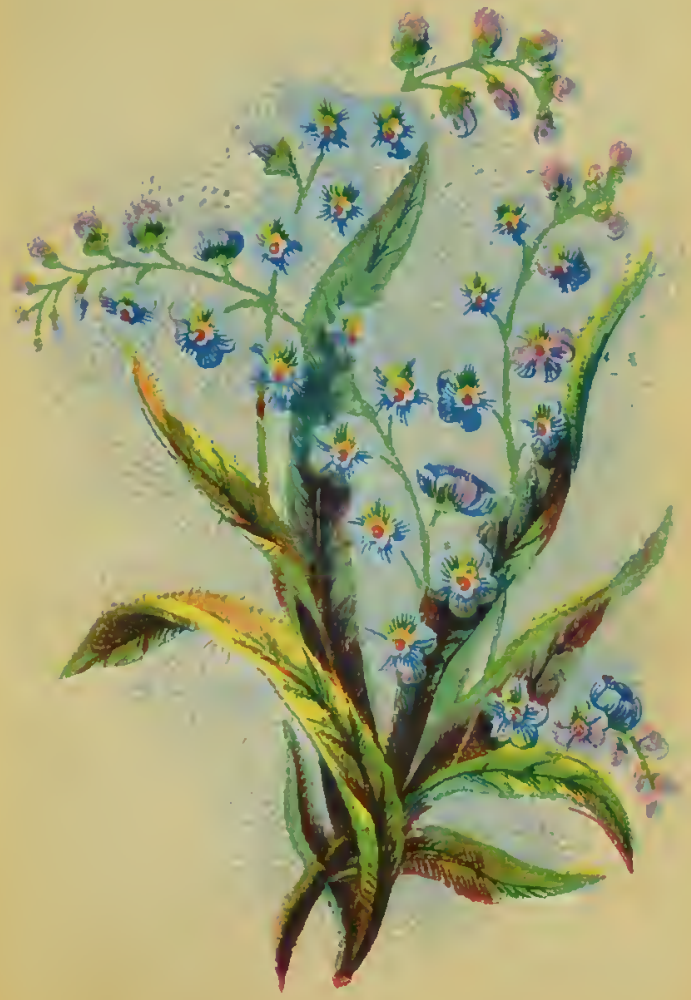



All thou hast loved, and lost, and treasured there. Where thy best thoughts must be!

Ay, prize them well, my child-

The bright, young blooming things that never die-

Pointing our hopes to happier worlds, that lie Far o'er this earthly wild!

\section{TO THE BRAMBLE FLOWER.}

\section{BY E. ELLIOTT.}

'THy fruit full-well the schoolboy kноwя, Wild bramble of the irake!

So, put thou forth thy s.. nll white rose;

I love it for his sake

Though woodbines flaunt and roses glow $\mathrm{U}$ er all the fragrant bowers,

Thou nced'st not be ashamed to show

Thy satin-threaded flowers;

For dull the eye, the heart is dull

That cannot feel how fair,

A mid all beauty, beautiful

Thy tender blossoms are!

How delicate thy gauzy frill!

How rich thy branchy stem!

How soft thy voice, when woods are atill. And thou sing'st hymns to them: 
While silent showers are falling slow And, 'mid the general hush, A sweet air lifts the little bough, Lone whispering through the bush! The primrose to the grave is gone; The haw thorn flower is dead; The violet by the moss'd gray stone Hath laid her weary head; But thou, wild bramble! back dost bring In all their beauteous power, 'The fresh green days of life's fair spring, And hoyhood's blossomy hour. Seorn'd bramble of the brake ! onee more

'Thou bidd'st me be a boy, To gad with thee the woodland's o'er, In freedom and in joy.

\section{CIPIIDREN OF THE SUN'S FIRST GLANCING.}

FROM SCHILLER.

CHILDREN of the sun's first glancing, Flowers tha: deck the bountoous eartls;

Ioy and mirth are round ye dancing: Nature smiled upon your birth; Light hath veined your petals tender, And with hues of matchless splendour 
Flora paints each dewy bell. But lament, ye sweet spring blossoms, Soul hath never thrilled your bosoms, All in cheerless night ye divell.

Nightingale and lark are singing Many a lay of love to you:

In your chaliced blossoms swinging, Tiny sylphs their sylphids woo: Deep within the painted hower Of a soft and perfumed flower, Venus once did fall asleep: But no pulse of passion darted Through your breast, by her imparted Children of the morning, weep.

When my mother's harsh rejection Bids me cease my love to speak, -

Pledges of a true affection, When your gentle aid I seek,Then by every voiccless token, Hope, and faith unclianged, are spoken, And by you my bosom grieves: Love himself among you stealeth And his awful form concealeth, Shut within your folding leaves. 


\section{¿ANGUAGE OF FLOWERS.}

BY H. W. LONGFELLOW.

SPAKE full well, in language quaint and clder,

One who divelleth by the castled Rhine, When he called thic flowcrs so blue and golden Stars, that in earth's firmament do shine.

Stars they are, wherein we read our history, As astrologers and seers of eld; Yet not wrapp'd about with awful mystery, Like the burning stars, which they beheld.

Wondrous truths, and manifold as wondrous, God hath written in those stars above; But not less in the bright flowerets under us Stands the revelation of his love.

Bright and glorious is that revelation, IV ritten all over this great world of ours; Making evident our own creation, In these stars of earth, - these golden flowers

And the Poet, faithful and far-seein Sees alike in stars and flowers, a part Of the self-same, universal Being, Which is throbbirg in his brain and heart. 
Gorgeous flowerets in the sunlight shining,

Blossoms flaunting in the eye of day, Tremulous leaves, with soft and silver lining,

Buls that open only to deeny;

Brilliant hopes, all woven in gorgeous tissues, Flaunting gaily in the golden light; Large desires, with most uneertain issues, Tender wishes, blossoming at night!

These in flowers and men are more than seemung Workings are they of the self-same powers, Which the poet, in no idle dreaming, Seeth in himself and in the flowers.

Every where about us are they glowing, Some like stars, to tell us Spring is born;

Others, their blue eyes with tears o'erflowing. Stand like Ruth amid the golden eorn;

Not alone in Spring's armorial bearing, And in Summer's green-emblazoned field, But in arms of brave old Autumn's wearing, In the eentre of his brazen shield;

Not alone in meadows and green alleys, On the mountain-top, and by the brink of sequestered pools in woodland valleys, Where the slaves of Nature stoop to drink: 
Not alone in her vast dome of glory, Not on graves of bird and beast alone, But in old eathedrals, high and hoary, On the tombs of heroes, earved in stons;

In the eottage of the rudest peasant, In ancestral homes, whose erumbling towers, Speaking of the Past unto the Present, 'Tell us of the ancient Games of Flowers;

In all places, then, and in all seasons, Flowers expand their light and soul-likt, wings, Teaehing us, by most persuasive reasons, How akin they are to human things.

And with ehild-like, eredulous affection, We behold their tender buds expand;Emblems of our own great resurreetion, Emblems of the bright and better land. 
THE STAR AND 'THE WATER-LILY.

\section{EY O. W. HOLMES.}

'Те Sun stepp'd down from his golden throne, And lay in the silent sea,

And the Lily had folded her satin luaves.

For a sleepy thing was she;

What is the Lily dreaming of ?

Why erisp the waters blue?

See, see, she is lifting her varnish'd lid :

Her white leaves are glistening through!

The Rose is cooling his burning cheek

In the lap of the breathless tide;

The Lily liath sisters fresh and fair,

That would lie by the Rose's side;

IIe would love her better than all the reat,

And he would be fond and true;

But the Lily unfolded her weary lids,

And look'd at the sky so blue.

liemember, remember, thou silly one,

How fast will thy summer glide,

Ind wilt thou wither a virgin pale,

Or flourish a blooming bride?

" $O$, the Rose is old, and thorny, and eold,

And he lives on earth," said she;

- Put the Star is fair and he lives in the air.

And he shall my britegroom be." 
But what if the storny cloud should como, And rufle the silver sea?

Would he turn his eye from the distant sky,

To smile on a thing like thee?

$O$, no! fair Lily, he will not send

One ray from his far-off throne;

The winds shall blow and the waves shall fiow, And thou wilt be left alone.

There is not a leaf on the mountain-top,

Nor a drop of evening dew,

Nor a golden sand on the sparkling shore,

Nor a pearl in the waters blue, 'That he has not eheer'd with his fickle smile,

And warm'd with his faithless beam,And will he be true to a pallid flower,

'I'hat floats on the quiet stream?

Alas, for the Lily! she would not heed,

But turn'd to the skies afar,

And bared her breast to the trembling ray

'That shot from the rising star;

'T'he eloud eame over the darken'd sky,

And over the waters wide;

She look'd in vain through the beating rain, And sank in the stormy tide. 


\title{
FLOWERS FOR THE HEART.
}

\author{
BY E. ELLIOTT.
}

FLowers! winter flowers! - the child is dead. The mother eannot speak :

O softly couch his little head, Or Mary's heart will break!

Amid those curls of flaxen hair This pale pink riband twine, And on the little bosom there Place this wan lock of mine.

How like a form in cold white stone, The eoffin'd infant lies! Look, Muther, on thy little one! And tears will fill thine eyes.

She cannot weep, more faint she growe, More deadly pale and still : Flowers! oh, a flower! a winter rose, That tiny hand to fill.

Go, seareh the fields! the lichen wet Bends o'er th' unfailing well; Beneath the furrow lingers yet The scarlet pimpernel. 
Peeps not a snowdrop in the bower, Where never froze th? spring ?

A daisy? Ah ! bring chuldhood's flower? The lualf blown daisy bring!

Yes, lay the daisy's little head Beside the little cheek;

O haste ! the last of five is dead! The clildless cannot speak !

\section{$\longrightarrow$ \\ THE AMARANTH.}

Crowns inwove with Amaranth and gold, Immortal Amaranth, a flower, which once In Paradise, fast by the Tree of Life, Began to bloom ; but soon, for man's offence, 'To Heaven removed, where first it grew, thero grows

And flowers aloft, shading the Fount of Life, And where the River of Bliss, through midst of

Heaven,

Rolls o'er Elysian flowers her amber stream; With these, that never fade, the spirits elect, Bind thrir resplendent locks. Milton 


\section{THE WALL-FLOWER}

\section{EY D. M. MOIR.}

The wall-flower-the wall-flower, How beautiful it bloorns!

It gleams above the ruin'd tower, Like sunlight over tombs;

It sheds a halo of repose

Around the wrecks of time;To beauty give the flaunting rose,

The wall-flower is sublime.

Flower of the solitary place!

Gray ruin's golden crown!

Thou lendest melancholy grace

'To haunts of old renown;

Thou mant lest o'er the battlement,

By strife or storm decay'd ;

And fillest up each envious rent Time's canker-tooth hath made.

Whither hath fled the choral band

That fill'd the abbey's nave?

Yon dark sepulchral yew-trces strnd

O'er many a level grave;

In the belfry's crevices, the dove

Her young brood nurseth well,

Whiist thou, lone flower! dost shed above

A sweet decaying smel!. 
In the season of the tulip cup,

When blossoms elothe the trees, How sweet to throw the lattice up, And scent thee on the breeze! The Butterfly is then abroad, 'The bee is on the wing, And on the hawthorn by the road The linnets sit and sing.

Sweet wall-flower-sweet wail-flower! Thou conjurest up to me, Full many a soft and sunny hour Of boyhood's thoughtless glee; When joy from out the daises grew In woodland pastures green, And summer skies were far more blus 'Than since they e'er have been.

Now autumn's pensive voice is heard Amid the yellow bowers, The robin is the regal bird, And thou the queen of flowers! He sings on the laburnum trees, Amid the twilight dim, And Araby ne'er gave the breeze Such scents as thou to him.

Rich is the pink, the lily gay, The rose is summer's guest ; Bland are thy charms when these decay of flowers, first., last, and best ! 
There may be gaudier on the bower, And statelier on the tree;

But wall-flower, loved wall-flower, Thou art the flower for me!

\section{THE I.AS'T ROSE OF SUMLMER.}

BY T. MOORE.

"Tis the last rose of summer

Left blooming alone,

All her lovely companions

Are faded and gone;

No flower of her kindred,

No rose-bud is nigh,

To refleet back her blushes

And give sigh for sigh.

I'll not leave thee, thou lone one

'To pine on the stem;

Since the lovely are sleeping,

Go sleep lhou with them.

'Ihus lsindly I scatter

Thy leaves on the bed,

Where thy mates of the garden

Lie scentless and dead.

Do soon may I follow

When friendships decay,

And from love's shining eirelo

The gems drop away: 
When true hearts lie wither'd

And fond ones are flown,

Oh ? who would inhabit

This eold world alone?

\section{THE RHODORA.}

I.INES ON BEING ASKED, WHENCE IS THF FLOWER ?

BY RALPH WALDO EMERSON.

Is May, when sea-winds piereed our solitudes, I found the fresh Rhodora in the woods, Spreading its leafless blooms in a damp nook, To please the desert and the sluggish brook; The purple petals, fallen in the pool, Made the blaek waters with their beauty gay ; Young RAPHAEL might eovet suel a sehool; The lively show beguiled me from iny way.

Rhodora! if the sages ask thee why This eharm is wasted on the marsh and sky, - Dear, tell them, that if eyes were made for seeing Then beauty is its own exeuse for being. Why, thou wert there, O, rival of the rose! I never thought to ask, I never knew.

But in my simple ignoranee suppose The eelfsame Power that brought me there, brought you. 
THE POETRY OF FLOWERS.

\title{
THE EVENING PRIMROSE.
}

\author{
BY G. LANGHORNE.
}

ThERE are that love tìe shades of life, And shun the splendid walks of fame;

There are that hold it rueful strife 'To risk A mbition's losing game;

'That far from envy's lurid eye The fairest fruits of genius rear, Content to see them bloom and die In friendship's small but kindly sphere.

Than vainer flowers, though sweeter far, The Evening Primrose shuns the day; Blooms only to the western star, And loves its solitary ray.

In Eden's vale an aged hind, At the dim's twilight's closing hour, On his time-smoothed staff reclined,

With wonder view'd the opening flowar:

"Ill-fated flower, at eve to blow," (In pity's simple thought he cries,) "Thy bosoni must not feel the glow Of splendid sıns, $0^{m}$ smiling skiıs. 
"Nor thee the vagrants of the field, The hamlet's little train behold;

Their eyes to sweet oppression yield, When thine the falling shades unfold.

"Nor thee the hasty shepherd heeds, When love has fill'd his heart with cares: For flowers he rifles all the meads; For walking flowers-but thine forbears.

Ah! waste no more that beauteous bloom, On night's chill shade that fragrant breati ; Let smiling suns those gems illume? Fair flower! to live unseen is death!"

Soft as the voice of vernal gales

'That o'er the bending meadows blow, Or streams that steal through even vales, And murmur that they move so slow.

Deep in her unfrequented bower, Sweet Philomela pour'd lier strain ; 'The bird of eve approved her flower, A th answer'd thus the anxious swain :-mo

\section{"Live unseen!}

By inoonlight shades, in valleys green, Lovely flower, we'll live unseen. Of our pleasures deem not liglitly, Laughing day may look more sprightly 
But I love the modest mien, Still I love the modest mien of gentle evening fair, and her star-train'd quece

"Didst thou, shepherd, never find Pleasure is of pensive kind? IIas thy coitage never known 'I'hat she loves to dwell alone? Dost thou not at evening hour Feel some soft and secret power Griding o'er thy yielding mind, Leave sweet serenity behind, While, all disarm'd, the cares of day Steal through the falling gloom awav? Love to think thy lot was laid In this undistinguish'd shade. Far from the world's infectious view 'Thy little virtues safely blew. Go, and in day's more dangerous howr: Guard thy emblematic flower." 


\section{THE WINTER NOSEGAY.}

\section{BY WILLIAM COWPER.}

What nature, alas! has denied

'T'o the delieate growth of our isle. Att has in a measure supplied,

And winter is deek'd with a smile. See, Mary, what beauties I bring

From the shelter of that sunny shed,

Where the flowers have the eharms of tne spring

Though ahroad they are frozen and dead.

'Tis a bower of Areadian sweets,

Where Flora is still in her prime,

A fortress to whieh she retreats

From the cruel assaults of the clime.

While carth wears a mantle of snow,

These pinks are as fresh and as gay

As the faircst and sweetest that blow

On the bcautiful bosom of May

Soe how they have safely survived

'The powers of a sky so severe; Sueh Mary's true love, that has lived

'I'hrougl many a turbulent year. 'T'he charms of the late-blowing rose Seem graced with a livelier hue, And the winter of sorrow best show

The truth of a friend sueh as you. 


\section{THE AL MOND-TREE.}

BY MISS EANDON.

F'leEting and falling,

Where is the bloom

Of yon fair Almond-tree $\hat{?}$

It is sunk in the tomb.

Its tomb wheresoever

The wind may have borne The leaves and the blossoms

Its roughness has torn.

Some there are floating

On yon fountain's breast, -

Some line the moss

Of the nightingale's nest,-

Some are just strewn

U'er the green grass below,

And there they lie stainless

As winter's first snow.

Yesterday, on the boughs

They liung scented and fair ;

To-day they are seatter'd

The breeze best knows where. 
To-morrow those leaves

Will he scentless and dearl,

For the hind to lament

And the earcless to tread.

And is it not thus

IVith each hope of the heart 1

With all its best feelings?-

Thus will they depart :

'They'll go forth to the world

On the wings of the air,

Rejoicing and hoping ;

But what will be there?--

False lights to deeeive,

False friends to delude,

Till the heart in its sorrow's

Left only to brood.

Over feclings erush'd, chill'd, Sweet hopes ever flown;

Like that tree when its greer learo And blossoms are gone. 


\section{TIJE LILY.}

BY JAMES G. PERCIVAL.

I HAD foun $\rfloor$ out a sweet green spot

Where a lily was blooming fair ;

The din of the eity disturb'd it not;

But the spirit that shades the quiet eot With its wings of love was there.

\section{I found that lily's bloom}

When the day was dark and ehill:

It smiled like a star in a misty gloom,

And it sent abroad a sweet perfume, Which is floating around mo, gtill.

I sat by the lily's bell,

And wateh'd it many a day :-

The leares, that rose in a flowing swell, Grew fuint and dinı, then droop'd and fell, And the flower had flown away.

I look'd where the leaves were laid, In withering paleness, by ;

And as gloomy thoughts stole on me, said, 'There's many a sweet and blroming maid Who w:ll soon as dimlv die. 


\section{T'HE MARYGOLD.}

BY G. WITHERS.

WHEx with a serious musing, I belold 'The grateful and obsequious Marygold, IIow duly, every morning, she displays IIer open breast when Phœbus spreads liis rays Ilow she observes him in his daily walk, Still bending tow'rds him her small slender stalk; IIow, when he down declines, she droops and mourns,

Bedew'd as 'twere with tears, till he returns; And how she veils her flowers when he is gone, As if she seorned to be look'd upon By an inferior eye; or did contemn 'I'o wait upon a meaner light than him: When this I meditate, methinks the flowers IIave spirits far more genero.ı thin ours, And give us fair examples 10 rlespise 'The servile fawnings and idolatries Wherewith we eourt these earthly things below Which merit not the service we bestow, But O, my God! though grovelling I appear Upon the ground, and have a rooting here Whieh hales ne downward. yet in my desiro To that which is above me I aspire, And all my best affections I profess T'o Ilim thot is the S:un of Rirhteousness. 


\section{THE POEARY CP FI,OWERS.}

Oh ! keep the morning of his incarnation, 'The burning noon-tide of his bitter passion, 'The night of his descending, and the height Of his ascension, - ever in my sight, 'I'hat, imitating him in what 1 may, I never follow an inferisr way.

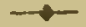 \\ THE LILY.}

BY SAMUEL TAYLOR COLERIDGE.

'Tне stream with languid murmur creeps In Lumin's flow'ry vale:

Beneath the dew the lily weeps, Slow waving to the gale.

'Cease, restless gale!" it seems to say' "Nor wake me with thy sighing! The honours of my vernal day On rapid wings are flying.

- To-morrow shall the traveller come IV ho late boheld me blooming ;

His searching eye shall vainly roam 'The dreary vale o Lumin." 


\section{CUPID AND THE DIAL}

Ove day, young frolic Cupid tried

To scatter roses o'er the hours,

And on the dial's face to hide

The course of time with many flowers.

By charce, his rosy wreatis haci wouid

Upon the hands, and forecd them on;

And when he look'd again, he found

The hours had pass'd, the time was done.

"Alas!" said love, and dropp'd his flowers

"I've lost my tinic in idle play;

The sweeter I would make the hours,

The quicker they arc pass'd away.'

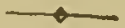

\section{THE CLOSED CONVOLVULLS.}

As hour ago, and sunny beams

Were glancing o'er each airy bell ; And thou wert drinking in those gleams,

Like beauty listening love's farcwell.

And now with folled drooping leaves,

Thou seenest for that light to mourn, Like unto one who fondly grieves

The hours that stay some friend's return. 
We cannot trace the hidden power Which folds thine azure petals up: When evening shadows dimly lower, And rlew-drops gem each floweret's cup.

Methinks I should not wish to be Like thee, a votary of the sun, To bask beneath his beams, yet fle Whene'er his brilliant race is run.

O dearer far the siient night; And lovelier far the star-lit slsy, Than gaudy day with sunbeams bright, And loud with nature's minstrelsy.

The night-bird's song is not for thee, The beautiful, the silver moon, The holy calm e'er flowers and tree; The stillness-nature's dearest boon.

Thou art a reveller of day,
A fair, rejoicing child of light ;

Glad, while the sunbeams o'er thee play But droping in the quiet night.

Like unto those who freely spend Their kindness in our happier hours, But should afflietion want a friend, They prove the sun's adoring flowers. 


\section{UMA N FLOWERS.}

\section{BY WILI.JAM HOWITT.}

SWEET Luey has ehosen the lily, as pale, And as lowly as she, still the pride of the vale: An emblem more fitting, so fair and retired, Iteart could not have ehosen, nor faney desired.

And Ellen, gay Ellen, a symbol as true, In the hare-bell has found, and its delieate blue: For ever the blossoms are fresh in her eyes, As dewy, as sweet, and more soft than the skies.

and Jane, in her thoughttulness, conserous of power,

Has gazed in her fervour on many a flower: Has chosen, rejeeted, then many combined To blazon her graces of person and mind.

W' hilst Isabel's faee, like the dawn, in one fluslFar need she not wander to bank and to bush; Wril the tint of her cheek the young Isabel knows,

For the blossom of healin is the beautiful rose.

And Mary, the pensive, who loves in the dusk Of the gardens to muse, when the air is all musk; Will leave all its beanties, and many they are, l'o gaze, meek in thought on the jessamine star. 
And Kate, the light butterfly Kate, ever gay. Will choose the first blossom that comes in ber way:

The cistus will please her a moment, and then Away will she flutter, and scttle again.

But Julia for me, with her heart in her eyes, 'The child of the summer, too warm to be wise: Is the passion-flower near her, with tendrils close curled,

She can smile whilst she suffers; 'tis hers for the world.

All are lovcly, all blossom of heart and of mind; Ail true to their natures, as Nature design'd; 'To cheer and to solace, to strcngthen, caress, And with love that can dic not to buoy and to bless.

With gentlcness might, and with wcakness, what grace!

Revelations from Heaven in form and on faec ;

Like the bow in the cloud, like the flower on the sod,

They ascend and deseend in my dreams as from God. 


\section{THE I YING BOY TO THE SLOE. BLOSSOM.}

\section{BY E. ELLIOTT.}

BEFore thy leaves thou com'st once more.

White blussom of the sloe?

Thy leaves will come as heretofore;

But this poor heart, its troubles o'er,

Will then lie low.

A month at least before thy time

Thou com'st, pale flower, to me;

For well thou know'st the frosty rime

Will blast me ere my vernal prime,

No more to be.

Why here in winter? No storm lours

O'er nature's silent shroud!

But blithe larks meet the sunny showere

IIigh o'er the doom'd untimely flowers

In beauty bow'd.

Sweet violets in the budding grove

Peep where the glad waves run; The wren below, the thrush above, Of bright tommorrow's joy and love Sing to the sun. 
And where the rose-leaf, ever bold.

Hears bees ehant hymns to God, 'The breeze-bow'd palm, moss'd o'er with gold, Smiles o'er the well in summer cold, And dasied sod.

But thou, pale blossorn, thou art eome,

And flowers in winter blow, 'T'o tell me that the worm makes room For me, her brother, in the tomb, And thinks me slow.

For as the rainbow of the dawn

Foretells an eve of tears,

A sunbeam on the sadden'd lawn I smile, and weep to be withdrawn In early years.

Thy leaves will come! but songful spring

Will see no leaf of mine; Her bells will ring, her bridemaids sing, When my young leaves are withering Where no suns shine.

Oh, might I breathe morn's dewy breath When June's sweet Sablaths chime! But, thine before my time, oh, death ! I go where no flow'r blossameth, Before my tinu. 
Even as the blushes of the morn

Vanish, and long ere noon

'The dew-drop dieth on the thorn, So fair I bloom'd; and was I born

'To die as soon?

To love my mother, and to die-

'To perish in my bloom !

Is this my sad, brief history :-

A tear dropp'd from a mother's eyo

Into the tomb.

He lived and loved-will sorrow say-

By early sorrows tried;

He smiled, he sigh'd, he pass'd away :

His life was but an April day,-

He loved, and died!

My mother smiles, then turns away,

But turns away to weep :

They whisper round me-what they say

I need not hear, for in the clay

$\mathrm{J}$ soon must sleep.

O, love is sorrow! sad it is

To be both tried and trute;

I ever trembled in my bliss :

Now there are farewells in it kiss, -

They sigh adieu. 
But woodbines flaunt when blue bells fade, Where Don reflects the skies; And many a youth in Shireeliffs' shade Will ramble where my voyhood play'd; 'Though Alfred dies.

Then panting woods the breeze will feel And bowers, as heretofure, Beneath their load of roses reel : But I through woodbine lanes shall sieal No more, no mors.

Well, lay me by my brother's side, Wliere late we stood and wept; For I was stricken when he diod.I felt the arrow as he sigh'd His last, and iss? 


\section{SONGS AND CHORUS OF THE FLOWERS.}

\section{BY LEIGH HUNT}

ROSES.

WE are blushing roses.

Bending with our tulness,

'Midst our close-capp'd sister bud

Warming the green coolness.

Whatsoe'er of beauty

Yearns and yet repuses,

Blush, and bosom, and sweet breath,

Teok a shape in roses.

Hold one of us lightly,-

See from what a slender

Stalk we bower in heavy blooms,

And roundnoss rich and tender:

Know yon not our only

Rival flower, - ihe numan?

Loveliest weight on lightest foot.

Jov-abundant woman? 


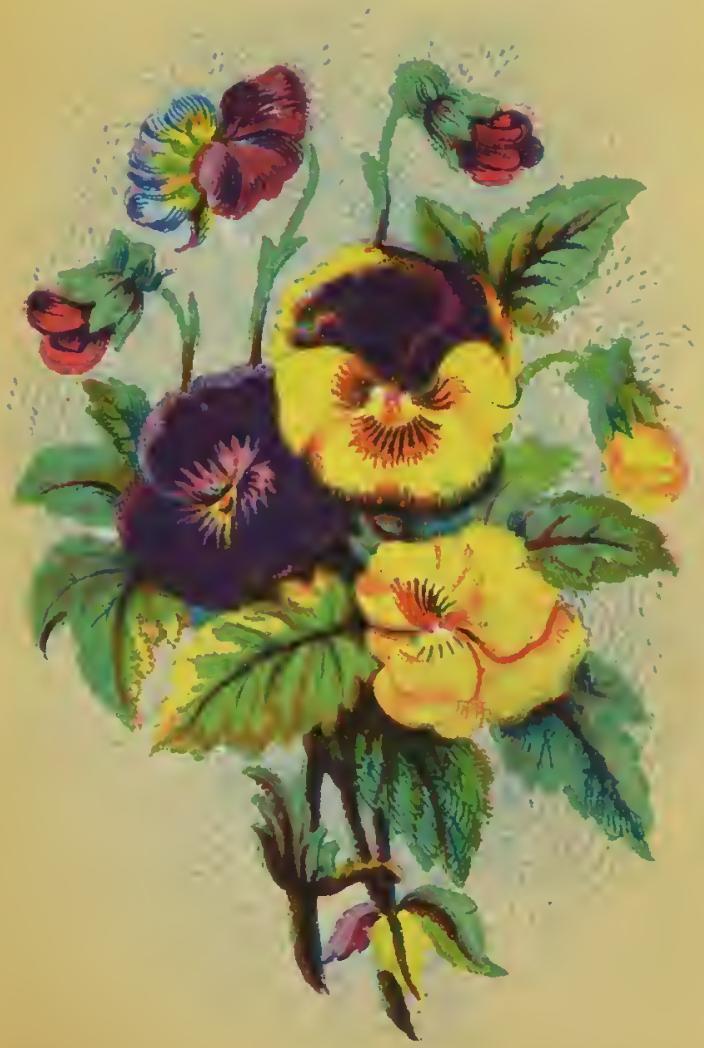


THE POETRY OF FLOWERS

$$
\text { JIIIES. }
$$

$W_{5}$ are lihes fair,

'I'he flower of virgin light;

Nature held us forth, and said,

" Lo! my thoughts of white"

Ever since then, angels

Hold us in their hands;

You may see them where they tako

In pietures their sweet stands.

Like the garden's angels

Also do we seem;

And not the less for being crown'd

With a golden dream.

Could you see around us

'The enamour'd air,

You would see it pale with bliss

To hold a thing so fair.

\section{POPTIES.}

$\mathrm{V}_{\mathrm{E}}$ are slumbering poppies,

Lords of Lethe downs,

Some awake, and some aslcep,

Sleeping in our erowns.

What perchance o!rr dreanis mav know,

Let cur serious beauty show. 
Central depth of purple,

Leaves more bright than rose,-

Who shall tell what brigitest though

Out of darkest grows?

Who, through what funereal pais,

Souls to love and peace attain?

Visions aye are on us,

Unto eyes of power;

Pluto's always-setting sun,

And Proserpine's bower:

There, like bees, the pale souls come

For our drink, with drowsy hum.

Taste, ye mortals, also;

Milky-hearted, we ;-

Taste, but with a reverent care,

Active-patient be.

Too much gladness brings to gloom

Those who on the gods presume.

\section{CHORUS.}

WE are the sweet flowers,

Born of sunny showers,

(Think, whene'er you see us, what our bcaut saith ;i

Utterance, mute and bright,

Of some unknown delight,

We fill the air with pleasure, by nur simpie breath: 


\section{IHE POETRY OF FLOWERS.}

All who see us love us, -

We hefit all plaees:

into sorrow we give smiles, - and unto graces, races

Mark our ways, how norseless

All, and sweetly voieeless,

Though the Mareh-winds pipe, to make our passage elear ;

Not a whisper tells

Where our small seed dwells,

Nor is known the monient green, when our tips appear.

We thread the earth in silenee,

In silenee build our bowers, -

And leaf by leaf in silence show, till we laugh a-top, sweet flowers.

The dear lumpish baby,

Humming with the May-bee,

Hails us with his bright star, stumbling througb the grass;

The honey-dropping moon,

On a night in June,

Kisses our pale pathway leaves, that felt the bridegroom pass.

Age, the wither'd clinger,

On us mutely gazes,

And wraps the thought of his last bed in his ehildhood's daisies. 
84

See (and seorn all duller

'Taste) how henv'n loves eolour;

How great Nature, clearly, joys in $r e d$ and green;-

What sweet thoughts she thinks

Of violets and pinks,

And a thousand flushing hues, made solely to bo seen :

See her whitest lilies

Chill the silver showers,

And what a red mouth is her rose, the woman of her flowers.

Uselessness divinest,

Of a use the finest,

Painteth us, the teachers of the end of use;

Travellers, weary eyed,

Bless us, far and wide;

Unto sick and prison'd thoughts we give sudden truee :

Not a poor town window

Loves its siekliest planting,

But its wall speaks lofier truth than Babyion:an vaunting.

Sagest yet the uses,

Mix'd with our sweet juices,

Whetaer man or May-fly, profit of the baim,

As fair fingers henl' $i$

Knights from the olden fieid 
We hold cups of mighticst force to give the wildest ealın.

Ev'n the terror, poison,

Hath its plea for blooming;

Life it gives to reverent lips, though death to the presuming.

And oh! our sweet soul-taker,

'That thief, the honey maker,

What a house hath he, by the thymy glen!

In his talking rooms

How the feasting fumes,

'Till the gold eups overflow to the mouths of men'

The butterflies come aping

Those fine thieves of ours,

And flutter round our rifled tops, like tiekled flowers with flowers.

See those tops, how beauteous!

What fair service duteous

Round some idol waits, as on their lord the Nine

Eifin eourt 'twould seem ;

And taught, perehanee, that dream

Whieh the old Greek mountain dreamt, upon nights divine.

To expounl such wonder

Human speech avails not;

Iet there dies no prorest weed, the: such a glory extales not. 


\section{Think of all these tr easurcs}

Matehless works and pleasures

Every one a marvel, more than thought tan sag

Then think in what bright showers

We thicken fields and bowers,

And with what hexps of sweetness half stifle wanton May :

Think of the mossy forests

By the bec-birds haunted,

na al! those Amazonian plains, lone lying 26 enchanted.

Trees themselves are ours;

Fruits are born of flowers ;

Peach, and roughest nut, were blossoms in the spring :

The lusty bee knows well

The new's, and comes pell-mell,

And dances in the gloomy thieks with darksome antheming.

Bencath the very burthen

Of planet-pressing oeean,

We wash our smiling clieeks in peace,--a though: for meek devotion.

Tears of Phobus,-missmgs

Of Cytherea's kissings,

Have in us been found, and wise men find them still; 


\section{Drooping grace unfurls Still Hyacinthus' curls,}

And Narcissus loves himself in the selfish till: Thy red lip, Adonis, Still is wet with morning;

And the step: that bled for thee, the rosy brier adorning.

$O !$ true things are fables,

Fit for sagest tables,

And the flowers are true things,-yet no fubles they ;

Fables were not more

Bright, nor loved of yore,-

Yet they grew not, like the flowers, by every old pathway:

Grossest hand can test us;

Fools may prize us never:-

$Y^{\dagger}$ et we rise, and rise, and rise,-marvels sweet for ever.

\section{Who shall say, that flowers}

Dress not heaven's own bowers?

(Wh) its love, without us, can fancy-or sweet floor?

Who shall even dare

To say, we sprang not there,-

and enme not down that liove might bring une piece of heaven the more? 
$O$ ! pray believe that angels

From those blue dominions,

Brought us in their white laps down, 'twixt theil golden pinions.

\section{'T'HE NARCISSUS.}

BY JOHN REATS.

W Narcissus pining o'er the untainted spring? In some delicious ramble he had found A little space, with boughs all woven round; And in the midst of all a elearer pool Than e'er refleeted in its p'easant eool The blue sky, here and there serenely peeping, l'hrough tendril wreaths fantastieally creeping. And on the bank a lonely flower he spied, A meek and forlorn flower, with nought of pride, Drooping its beauty o'er the watery elearness, l'o woo its own sad image into nearness: Deaf to light Zephyrus it would not move, But still would seem to droop, to pine, to love. so while the poet stood in this sweet spot, Some fainter gleamings o'er his faney shot; Nor was it long ere he had told the tale Df young Narissus, and sad Ei ho's vale. 
THE POETRY OF FLOWERS.

\section{ON RECEIYING A BRANCH OF MEZEREON.}

WHICH FLOWLRED AT WOODSTOCK, DEC. 1809.

BY MRS. TIGHE.

ODours of spring, my sense ye eharm

With fragranee premature;

And, mid these days of dark alarm

Almost to hope allure.

Methinks with purpose soft ye eome

'To tell of hrighter hours,

1)f May's blue skies, abundant bloom,

Her sunny gales and showers.

Alas! for me sliall May in vain

The powers of life restore;

These eyes that weep and watch in pain

Shall see her eharms no more.

No, no, this anguish eannot last!

Beloved friends, adieu!

The bitterness of death were past,

Conld I resign but you.

But ols ! in every mortal pang

That rends my soul from life,-

'That soul, which seems on you to nailf

'Through each eonvulsive strife, 
Even now, with agoniziug grasp

Of terror and regret,

T'o all in life its love would elasp,

Clings elose and eloser yet.

Yet, why, immortal, vital spark !

'I'hus mortally opprest?

Look up, my soul, through prospeets dark

And bid thy terrors rest;

Forget, forego thy earthly part,

Thine heavenly being trust:

Ah, vain attempt ! my eoward heart

Still shuddering elings to dust.

$O$ ye ! who soothe the pangs of death With love's own patient eare, Still, still retain this fleeting breath, Still pour the fervent prayer. And ye, whose smile must greet my eye No more, nor voiee my ear, Who breathe for me the tender sigh, And shed the pitying tear;

Whose kindness (though far, far removerd) My grateful thougints pereeive, Pride of my life, esteem'd, beloved, My last sad elaim reeeive !

Oh ! do not quite your friend forget, Forget alone her faults; And speak of her with fond regret Wh asks your lingering thoughts. 
4

\section{'THE LIT'I'LE RED ROSE.}

FROM GOETHE.

A Boy caught sight of a rose in a bower--

A little rose slily hiding

Among the boughs; $O$ ! the rose was bright And young, and it glimmer'd like morning light. 'I'be urehin sought it will haste; 'twas a flower A child indeed might take pride inA little rose, little rose, little red rose, A mong the bushes hiding.

'The wild boy shouted-" I'll pluek thee, rose, Little rose vainly hiding Among the boughs;" but the little rose spoke"I'll prick thee, and that will prove no joke; Unhurt, $\mathrm{O}$ then will I moek thy woes, Whilst thou thy folly art eliding." Little rose, little rose, little red rose, Among the bushes hiding !

But the rude boy laid his hands on the flower, 'I'he little rose vainly hidıng Among the boughs; $\mathrm{O}$, the rose was eaught, But it turned again, and pricked and fought, And left with its spoiler a smart from that hour

A pain for ever abidung; I.ittle rose, little rose, little red rose,

Among the bushes hiding ! 


\section{THE VOICE OF 'I'HE FLOIVERS.}

\section{BY MARY ANNE LROWNE.}

\section{Blossoms, that Inwly bend,}

Shutting your leaves from evening's ehilly dew While your rich odours heavily aseend,

'The flitting winds to woo.

I walk at silent eve,

When scarce a breath is in the garden bowers, And many a vision and wild fancy weave,

'Midst ye, ye lovely flowers;

Beneath the cool green boughs, And perfumed bells of the fresh blossom'd line, That stoop and gently toueh my feverish brow

Fresh in their summer prime;

Or in the mossy dell,

Where the pale primrose trembles at a breath; Or where the lily, by the silent well,

Beholds her form beneath ;

Or where the rich queen-rose

Sits, throned and blushing, 'midst her leaves and moss ;

Or where the wind-flower, pale and fragile. blows.

Or violets banks emboss. 
Here do I love to be, -

Mine eye alone in passionate lovo to dwell

Jpon the loneliness and purity

of every bud and bell.

Oh blessedness, to lie,

By the clear brook, where the long benuet dips!

'I'o press the rose-bud in its purity

Unto tle burning lips!

To lay the weary head

Upon the bank, with daisies all beset, Or with bared feet, at eariy dawn to tread

O'er mosses cool and wet?

And then to sit, at noon,

When bees are humming low, and birds are etill, And drowsy is the faint uncertain tone Of the swift woodland rill.

And dreams can then reveal

l'hat, wordless though ye be, ye have a tone A language and a power, that I may feel,

'I'lurilling my spirit lone.

Ye speak of Hope and Love,

Bright as your hues, and vague as your perfume; of changeful, fragile thoughts, that brightly move

Men's hearts amidst their gloom. 
Ye speak of human life,

Its mystery-the beautiful and brief;

Its sudden fading 'midst the tempest strifs,

Even as a delicate leaf.

And, more than all, ye speak

Of might, and power, of mercy, of the One Eternal, who hath strew'd you fair and meek,

To glisten in the sun;

To gladden all the earth

With bright and beauteous emblems of his grexa, That showers its gifts of uncomputed worth

In every clime and plas. 


\section{CUPID INSPIKLNG PLANTS WIIU LOVE.}

\section{B Y D Y E R.}

Treming with Nature's lively hues, I bid thee welcone, genial Spring ! While fancy wakes her thousand lyres, And woods and vales responsive sing.

She comes; lo! W1NTER scowls away";

Harmonious forms start forth to view';

Nymphs tripping lir.he in circles gay, Deck'd in their robes of virgin hue.

I'hen I, on am'rous sportings bent, Like a sly areher take my stand; IVide through the world my shafts are sem; and every creature owns my hand.

First man, the lord of all below, A captive sinks ineneath my dart; And lovely woman, made to glow, Yields the dominion of her heart.

Through sea, and earth, and boundless sk. $\mathbf{y}$. 'The fond subjection all must prove, Whether they swim the stream or fly, Mountain, or vale, or forest rove. 
With its dark buds and leaves, wandering astray, And Howers azure, black, and streak'd with gold; Fairer than any waken'd eyes behold.

And nearer to the river's trcmbling edge 'There grew broad flag-flowers, purple prankı with white,

And starry river buds among the sedge, And floating water-lilies, broad and bright, Which lit the oak that overhung the hedge

With moonlight beams of their own waterg light ;

And bulrushes and reeds of sueh deep green As soothed the dazzled eye witl sober sheen.

Methought that of these visionary flowers

I made a nosegay, bound in such a way That the same hues which in their natural bowers

Were mingled or opposed, the like array Kept these imprison'd ehildren of the horrs Within my hand,- and then, elate and gay, I hasten'd to the spot whenee I had come, I'hat I might there present it! $-\mathrm{Oh}$ ! to whom ! 


\section{TIIE POETRY OF FLOIVERS.}

\section{WILD FLOWERS.}

\section{BY SHELLY.}

I DRas M'D that, as I wander'd by the way, Bare winter suddenly was ehanged to sprung,

And gentle odours led iny steps astray, Mix'd with a sound of waters murmuring Along a shelving bank of turf, whieh lay

Under a eopse, and hardly dared to fling Its green arms round the bosom of the stream, But kiss'd it and then fled, as thou mightest in

a dream.

There grew pied wind-flowers and violets, Daisies, those pearl'd Areturi of the earth, The eonstellated flower that never sets;

Fiant oxlips; tender blue-bells, at whose birth The sod searee heaved; and that tall flower that wets

Its mother's faee with heaven-eolleeted tears, When the low wind, its playmate's voiee, it hears.

And in the warm hedge grew lush eglantine, Green eowbind and the moonlight-eolour'd May,

And cherry blossoms, and white eups, whose wine Was the bright dew yet drain'd not by the day; And witd roses, and ivy serpentine. 
Nor less the garden's sweet domain, The mossy heath or vcrdant mead, 'The tow'ring hill, the level plain, And fields with blooming life o'erspread

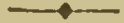 \\ THE ALPINE VIOLET.}

\section{BY LORD BYRON.}

T'ue Spring is come, the violet's gone, The first-born child of the early sun; With us she is but a winter flower, The snow on the hills cannot blast her bower: And she lifts up her dewy eye of blue, 'To the youngest sky of the self-same hre.

But when the spring comes with her host Ot flowers, that flower, beloved the most, Shrinks from the crowd, that may confuse Her heavenly odours and virgin hues.

Pluck the others, but still remember 'Their herald, out of dire Dceember; The morning star of all the flowers, The pledge of daylight's lengthen'd hours, And 'mid the roses, ne'er forget The virgin, virgin viole. 


\section{TO A DAISY.}

B W W R D W ORTH.

BRIGuT flower, whose home is every where ' A pilgrim bold in Nature's care, And oft, the long year through, the heir

Of joy or sorrow ;

Methinks that there abides in thee Some concord with humanity, Given to no other flower I see The forest through!

And wherefore? Man is soon deprest ; A thoughtless thing who, once unblest, Does little on his mernury rest,

Or on his reason:

But thou wouldst teach him how to find A shelter under every wind ;

A hope for times that are unkind, And every seas on. 


\section{THE I VY SONG.}

BY MRS. HEMANS.

$0 \pi$ ! how eould faney erown with thee

In ancicnt days the god of wine,

And bid thee at the banquet be

Companion of the vine!

Iry ! thy home is where each sound

of revelry hath long been o'er:

Where song and beaker onee went rouns

But now are known no more.

Where long-fallen gods reeline,

There the place is thine.

The Roman on his battle plains,

Where kings before his eagles bent,

With thee, amidst exulting strains,

Shadow'd the victor's tent ;

Though shining there in deathless green,

Triumphally thy boughs might wave

Better thou lovest the silent scene

Around the vietor's grave.

Urn and seulpture half-divine

Yield their plaee to thine.

The eold halls of the regal dead,

Where lone the Italian sunbeams dwoll, Where hollow sounds the lightest tread- 
Ivy ! t.1ey know thee well! And far above the festal vine,

Thou wavest where once proud banners hung Where mouldering turrets erest the Rhine,

-The Rhine, still fresh and young: 'Tower and ranipart o'er the Rhine, Ivy! all are thine!

High from the fields of air look down

'I'hose eyries of a vanish'd raee, Where harp, and battle, and renown,

Have pass'd, and left no traee.

But thou art there : serenely briglit,

Meeting the mountain storms with bloors, Thou that wilt elimb the loftiest height,

Or erown the lowliest tomb! Ivy, Ivy! all are thine, Palaee, hearth, and shrine.

'Tis still the same; our pilgrim tread O'er elassie plains, through deserts free, On the mute path of ages fled, Still meets decay and thee. And still let man his fabries rear, August in beauty, stern in power, -Days pass-lhou Ivy never sere! And thou shalt have thy dower.

All are thine, or must be thine! -Temple pillar, shriro! 


\section{DAFFODILS.}

B Y WORDS WORTH.

I WANDER'D lonely as a eloud

'That floats on high o'er vales and hil.t.

When all at once I saw a erowd,

A host of golden daffodils;

Beside the lake, beneath the trees,

Fluttering and daneing in the breeze.

Jontinuous as the stars tlat shine

And twinkle in the Milky-way,

I'hey stretch'd in never-ending line

Ilong the margin of a bay:

Cen thousand saw I at a glanee,

'Tossing their heads in sprightly dance.

The waves beside them daneed; but they

Dutdid the sparkling waves in glee:

A poet eould not but be gay,

In such a joeund company;

: gazed-and gazed-but little thought What wealth the show to me had brought

For oft when on my couch I lie,

In vaeant or in pensive mooả,

'They flash upon that inward eye

Whieh is the bliss of solitude;

And then my heart with pleasure fills,

And dar.es with the daffodils. 


\section{A D ONIS' COUCH.}

\section{BY JOHN KEATS.}

(IN a silken couch of rosy pride, In unidst of all, there lay a slecping youth of fondest beauty ; fonder in fair sooth, 'Than sighs could fathom, or eontentment reach: And eoverlids gold-tinted like the peach, Or ripe October's faded marigolds, Fell sleek about him in a thousand foldsNot hiding up an Apollonian eurve Of neck and shoulder, nor the tending swerve Of knee from knee, nor ankles pointing light; But rather giving them to the fill'd sight, Officiousiy. Sideway his face reposed On one white arm, and tenderly unclosed, By tenderest prcssure, a faint damask mouth, l'o slumbery pout ; just as the morning south Disparts a dew.lipp'd rose. Above his head Four lily stalks did thcir wide honours wed l'o make a coronet; and round him grew All tendrils green, of every bloom and hue, l'ogether intertwined and trammell'd fresh: l'he vine of glossy sprout; the ivy mesh, shading its Eithiop berries; and woodbine, of velvet leaves and bugle blooms divine; Donvolvulus in streaked vases flush ; l'he creeper, mellowing for an autumn blush: 
And virgin's-bower, trailing airily ;

With others of the sisterhood. Hard by,

Stood serene Cupids watching silently.

One, lneeling to a lyre, touched the stringe, Muffing to death the pathos with his wings; $A$ nd, ever and anon, uprose to look At the youth's slumber; while another took A willow bough, distilling odorous dew, And shook it on his hair; another flew In through the woven roof, and fluttering wise, Rain'd violets upon his slecping eyea. 


\section{FLOWER FANTASIES.}

\section{BY LOUISA ANN TWWMLEY.}

On! there is musie to the spirit's ear

In every sigh

Heaved by the rose's bosom to the air

That winnows by ;

And there is poetry in every leaf,

Whose blush speaks pleasure, or whose tears tell grief.

There is romance in every stem that bends

In motion soft

Beneath the wind that rustles in the tall

Tree-tops aloft,

And 'mid their branches whistlingly doth blow, While it but fans the flowers that sleep below

We know they sleep; at eve the Daisy small

Foldeth all up

Her blush-tipp'd rays ; and the wave's empres: shuts

Her star-lit cup :

And each fair flower, though some with open eye, idistens and yields to nature's lullaby.

* The Water Lily. 
The nodding Foxglove slumbers on he: stalk ; And fan-like ferns

Seem poised still and slcepily, until

The morn rcturns

With singing-birds and beams of rosy ligh :,

'T'o bid them dance and frolic in delight.

The drowsy Poppy, who has all the day

Proudly outspread

His scarlet mantle, folds it closely now

Around his head;

And, lull'd by soothing balm that his own leaver distil,

Sleeps while the night-dews fall upon the moon. lit hill.

'I'he fragrance is the spirit of the flower,

$E^{\prime} c n$ as the soul

is our ethereal portion. We can ne'er

Hold or control

One morc than other. Passing swect must be 'The visions, gentle things, that visit ye'

How happily ye live in the pure light

Of loveliness!

Do ye not feel how deeply - wondrously

Yc checr and bless.

Our cliecker'd sojourn on this weary earth,

Whose wildest, drearisst spots to F'rowers have given birth ? 
- Do not ye joy to know the pure deliglit

\section{With which we gazc}

Upon your glorious forms?-Are ye not glad

E'en in the praise

Which our enraptured wonder ever tells

While poring o'er the wealth that in ye dwells:

That wcalth of thought, of beauty, and of love,

Which may be found

In each small common herh that springs from out

The teeming ground?

Do not ye feel that ye do deeply bless

Our harsher souls by your dear loveliness?

Olı! if 'tis given unto ye to know

The thrilling power

Of memories and thoughts that can be read

E'en in a flower,

How ye must all rejoice beneath each look

Which reads your beauty, like an open book !

We love its silent language: strong, though stilh

Is that unheard

But all-pervading harmony:-it breathes

No utter'd word,

But floats around us, as, in happy dream,

We feel the soft sigh of a waveless stream.

So, love of nature's harmony can bless

And gladde $\mathrm{n}$ ever 
The heart and faney, as pellucid wave

\section{Of fount or river}

Flings back more bright what bright doth on it fall, And its own radia ice lends where else were none at all.

\section{SONNET.}

\section{B Y S P E N S E R.}

SwEET is the Rose, but growes upon a brere; Sweet is the Juniper, but sharpe his bough; Sweet is the Egrlantine, but prieketh nere; Sweet is the Firbloom, but his branches rough, Sweet is the Cypress, but his rind is tough, Sweet is the Nut, but bitter is his pill; Sweet is the Broome-flowcre, but yet sowre enough ;

And sweet is Moly, but his roote is ill. So every sweet with sowre is tempred stlll, 'That maketh it be eoveted the more: For easic things that may be got at will, Most sorts of men loe set but little store. Why then should 1 account of little paine, That endlcss pleasure shall unto me gaine f 
THE PCETRY OF FLC WERS.

\section{'T' H E F L O W ER-D I A L.}

\section{BY MRS. HEMANS.}

"I'was a lovely thought to mark the hours, As they floated in light away, By the opening and the folding flowers, That laugh to the summer's day.

Thus had eaeh moment its own rieh hue, And its graeeful eup and bell, In whose eolour'd vase might sleep the dew, Like a pearl in an oeean shell.

'l'o such sweet signs might the time have flow'd In a golden eurrent on, Ëre from the garden, man's first abode,

The glorious guests were gone.

So might the days have been brightly told'I'hose days of song and dreams,When shepherds gather'd their flocks of old, By the blue Arcadian streams.

So in those isles of delight, that rest

Far off in a breezeless main, Whieh many a bark, with a weary quest,

Has sought, but still in vain. 
Yet is not life, in its reol flight, Mark'd thus-even thus-on earth, By the closing of one hope's delight, And another's gentle birth ?

Oh! let us live so that flower by flower, Shutting in turn, may leave A lingerer still for the sunset hour, A enarm for the shaded eve.

\section{SPRING FLOWERS.}

BY SHAKSPEARE.

Daffodils

That conie before the swallow dares, srid take I'he winds of Mareh with beanty; violets, dim. But sweeter than the lids of Juno's eyes, Or Cytherea's breath; pale primroses, I'hat die unmarried, ere they can behold Bright Phœbus in his strength;

Bold oxlips, and The crown imperial; lilies of all kinds, The flower-de-luce leing one. 


\section{BOWING ADORERS.}

\section{BY CLARE.}

BowIXg adorers of the gale,

Ye Cowslips delicately pale,

Upraise your loaded stems;

Untold your cups in splendour, speak!

Who deck'd you with that rucldy streak,

And gilt your golden gems?

Violets, sweet tenants of the shade,

In purple's richest pride array'd,

Your errand here fulfil;

Go bid the artist's simple strain

Your lustre imitate in vain,

And match your Maker's skill.

Daisies, ye flowers of lowly birth. Eimbroiderers of the carpet eartl,

That stud the velvet sod;

Open to Spring's refreshing aur,

In sweetest smilingr bloon declare

Your Makır, and mv God. 


\section{F R A G M E N T.}

BY CQWPER.

Sore clothe the soil that fceds them, far aiffused And lowly creeping, modest and yet fair, Like virtue, thriving most whcre little seen; Some more aspiring catch the neighbour shrub IVith clasping tendrils, and invest his branch, Else unadorn'd, with many a gay festoon, And fragrant chaplet, recompensing well The strength they borrow with the grace they lend.

\section{$\longrightarrow$ \\ TO A MOUNTAIN DAISY,}

OX TURNING ONE DOWN WITII THE PLOUGR,

BY BURNS.

WEE, modest, crimson-tipped flower, 'Thou'st met me in an evil hour;

For I maun crush among the stour

Thy slender stem;

To spare thee now is past my power,

Thou bonnie gem. 


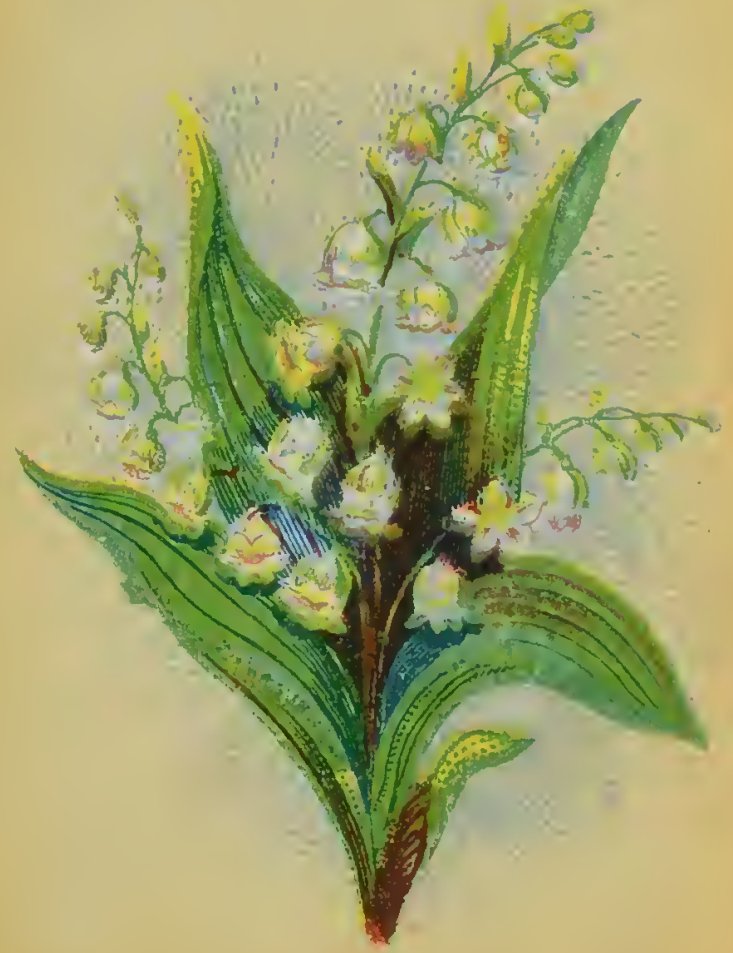



Alas! it's no thy neebour sweet, The bonnie lark, eompanion meet! Bending thee 'mang the dewy weet! Wi' speckled breast, When upward springing, tlithe, to greet The purplin' east.

Cauld blew the bitter biting north Upon thy early, humble birth : Yet eheerfully thou glinted forth Amid the storm, Searee rear'd above the parent earth, 'I'hy tender form.

The flaunting flowers our gardens yield, High sheltering woods and wa's maun shield; But thou, beneath the random bield O' elod or stane, Adorns the histie stibble-field, Unseen, alane.

There, in thy scanty mantle elad, 'l'hy snowy bosom sunward spread, Thou lifts thy unassuming head In humble guise;

But now the share uptears thy bed, And low thou lies!

Sueh is the fate of artless maid, Sweet flowerct of the rural shade' 
By love's simplicity betray'd,

$$
\text { And guileless trust ; }
$$

Till she, like thee, all soil'd, is laid

$$
\text { Low i' the dust. }
$$

Sueh is the fate of simple bard, On life's rough oeean luekless starr'd ! Unskilful he to note the card

$$
\text { Of prudent lore, }
$$

Till billows rage, and gales blow hard, And whelm him o'er!

Such fate to suffering worth is given, Who long witl wants and woes has strivet By human pride or eunning driven 'To misery's brink, Till, wrench'd of every stay but heaven, He ruin'd sink !

E'en thou who mourn'st the Daisy's fate, 'That fate is thine-no distant date; Stern Ruin's ploughshare drives elate, Full on thy bloom, Till cr'ssh'd veneath the furrow's weight, Shall be thy doom! 


\section{THE BROKEN FLOWER,}

\section{BY MRS. HEMANS.}

$\mathrm{Ou}$ ! wear it on thy heart, my love! Still, still a little while!

Sweetnuss is lingering in its leaves,

Though faded be their smile.

Yet, for the sake of what hath been, $\mathrm{Oh}$ ! cast it not away!

'Twas born to grace a summer scene, A long, bright, golden day,

A long, bright, golden day !

My love,

A little while around thee, love !

Its fragrance yet shall eling, 'Telling that on thy heart hath lain.

A fair, though faded thing.

But not even that warm heart hath power

To win it back from fate :-

Öh! I am like thy broken flower,

Cherish'd too late, too late,

Cherish'd, alas! too 'ne

My love ' 


\section{TO THE SUNFLOWER.}

PRIDE of the garden, the beauteous, the regis, The erown'd with a diadem burning in gold; Sultan of flowers, as the strong-pinion'd eagle And lord of the forest their wide empire hold.

Let the Rose boast her fragrance, the soft galea perfuming,

The 'l'ulip unfold all her fair hues to me:

Vet though sweet be their perfume, therr rainbow dyes blooming,

I turn, noble Sunflower, with more love to thee.

'There are some think thy stateliness haughty, dis. daining, -

Thy heaven-seeking gaze has un eharm for their eyes ;

'Tis because the pure spirit within thee that's reigning

Exalts thee above the vain pleasures they prize.

Emblem of eonstancy, whilst he is beaming,

For whom is thy passion so steadfast, so true; Way we, who of faith and of love are aye dreaming:

Be tanght to remember this lesson by you!

If on eartl, like the Sunflower, cur soul's bes! devotion 
Shall turn to the souree of Truth's far-beaming, rays;

O now blest, how triumphant, shail be our emotion,

When the bright 'Sun of Righteousness' bursis on our gaze.

\section{'THE ROSE AND THE GAUN'TLET.}

\section{BY JOHN STERLING.}

Low spake the Knight to the peasant girl, "I tell thee sooth-I am belted Earl ; Fly with me from this garden small, And thou shall sit in my castle's hall.

"Thou shalt have pomp, and wealth, and pleasure,

Joys beyond thy faney's measure;

Here with my sword and horse I stand, To bear thee away to my distant land.

"Take, thou fairest! this full-blown rose, A token of Love that as ripely blows." With his glove of steel he plueked the token, But it fell from his gauntlet crushed and broken. 
"Tho maiden exelaimed-" Thou exe'st, Sis Knight,

"ihy fingers of iron ean only smite; And, like the rose thou hast torn and scatter'd, I in thy grasp should be wreck'd and shatter'd."

She trembled and blush'd, and her glanees fell; But she t:rn'd from the Kright, and said "Fare well ;"

"Not so," he cried, "will I lose my prize, I heed not thy words, but 1 read thine eyes."

He lifted her up in his grasp of steel, And he mounted and spurr'd with furious heel; But her cry drew forth her hoary sire, Who snateh'd his bow from above the fire.

Swift from the valley the warrior fled, Swifter the bolt of the eross-bow sped: And the weight that pressed on the flept.fon horse,

W'as the living man, and the woman's corse.

That morning the rose was hright of hue : That morning the maiden was fair to view : But the evening sun its beauty shed On the withered leaves, an the maiden dead. 


\section{THE R OSE.}

BY WALIER.

Go, lovely rose!

Moll her that wastes her time on $\mathrm{nis}$

That now she knows, When I resemble her to thee, How sweet and fair she seems to bs.

Tell her that's young And shuns to have her graees spied, That hadst thou sprung In deserts where no men abide, 'Thou must have uncommended died.

Small is the worth

Of beauty from the light retired ;

Bid her come forth, Suffer herself to be desired; And not blush so to be admired.

\section{Then die, that she}

'The ccmmon fate of all things rare

May read in thee;

How small a part of time they share Ihat are so wondrous sweet and fair. 
Yet, though thou fade,

From thy dead leaves let fragrance rive;

And teach the maid

'I'hat goodness time's rude hand defies;

'Ihat virtue lives when beauty dies

\section{HEART'S-EASE.}

[ USED to love thee, simple flower, To love thee dearly when a boy; For thou didst seem in ehildhood's hour The smiling type of ehildhood's joy.

But now thou only work'st my grief, By waking thoughts of pleasures fled Give me-give me the wither'd leaf, That falls on Autumn's bosom dead.

For that ne'er tells of what has been, But warns me what I soon shall be; It looks not back on pleasure's seene. But points unto futurity.

I love thee not, thou simple flower, For thou art gay, and I am lone; Thy beauty died with ehildhood's hourThe Heart's-ease from my path is gone. 


\title{
THE MOSS-ROSE.
}

BY JOHN STERLING.

\begin{abstract}
Mossy rose on mossy stone, Flowering 'mid the ruins lone,

have learnt, beholding thee, Youth and Age may well agree.
\end{abstract}

Baby germ of freshest hue, Out of ruin issuing new ; Moss a long laborious growth, And one stalk supporting both:

Thus may still, while fades the past, Life eome forth again as fast;

Happy if the relics sere

Deck a eradle, not a bier.

Tear the garb, the spirit flies, Aud the heart unshelter'd, dies; Kill within the nursling flower, Searee the gre?n survives an hour.

Ever thus together live, And to man a lesson give, Moss, the work of vanished years, Rose, that bit to-day appears. 
Moss, thet covers dateless tomt $\mathbf{8}$; Bind with early swect that blooms; Childhood thus, in happy rest, Lies on ancient Wisdom's brcast.

Moss and Rose, and Age and Youth, Flush and Verdure, Hope and Truth, Yours be peace that knows not strifo, Onc the root and one the life.

\section{$\rightarrow+$ \\ THE IIYACINTII.}

BY ĆSIMIR.

Crild of the Spring, thou charming flower,

No longer in confinement lie, Arise to light, thy form discover,

Rival the azure of the sky.

'The rains arc gone, the storms arc o'er; Winter retires to make thee way; Come then, thou sweetly blooming flower, Comc, lovely stranger, eome away.

'The sun is dress' $d$ in beaming smiles, 'To give thy beauties to the day: Young zephyrs wait with gentlest gales, To fan thy bcrom as they play. 


\title{
FLOWERS FOR TIE GRAVE.
}

\author{
BY N. P. WILLIS.
}

nom, gentle flowers ' my ehild would pass to heaven!

Ye look'd not for her yet with your soft eyes, Oh watehful ushers at Death's narrow door? But lo! while you delay to let her forth, Angels, beyond, stay for her! One long kiss From lips all pale with agony, and tears, IVrung after anguish had dried up with fire The eyes that wept them, were the cup of life IIeld as a welcome to her. Weep! oh mother: But not that from this eup of bitterness $\Lambda$ eherub of the sky has turn'd away!

One look upon thy face ere thou depart! My daughter! It is soon to let thee go! Ny daughter! With thy birth has gush'd a spring I knew not of-filling my heart with tears, And turning with strange tenderness to thee-I love-oh God! it seems so-that must flow Far as thou fleest, and 'twixt heaven and me, IIeneeforward, be a bright and yearning ehain Drawing me after thee ! And so, farewell! "Tis a harsh world, in whieh affeetion knows No place to treasure tp its loved and lost But the foul grave! 'Thou, who so late wast sleeping

Warr: in the cilose fold of a mother's heart 
Scarce from her breast a single pulsc recei ing But it was sent thec with some tender thought, How can I lcave thee-lere! Alas for man ' 'The hcrb in its humility may fall And waste into the bright and genial air, While we-by hands that ministered in life Nothing but love to us-are thrust away'I'he earth flung in upon our just cold bosoms, And the warm sunshine trodden out for ever'

$Y$ et have 1 chosen for thy grave, my child, A bank where I have lain in summer hours, And thought how little it would seem like dcath 'I'o sleep amid such loveliness. The brook, 'T'ripping with laughter down the rocky steps 'I'hat lead up to thy bed, would still trip on, Breaking the dread hush of the mourners gone; 'I'he birds are never silent that build here, 'Trying to sing down the more vocal waters; The slope is beautiful with moss and flowers, And far below, seen under arching leaves, Gritters the warm sun on the village spire. Puinting the living after thec. And this Soems like a comfort; and, replacing now The flowers that have made room for thee, I go 'T'o whisper the same peace to her who licsRobb'd of her child and lonely. 'T'is the work Of many a dark hour, and of many a prayer, To bring the heart back from an infant gone. Hope must give o'er, and busy fancy blot The inages from all the silent rooms, 
And every sight and sound familiar to het Unco its sweetest link-and so at last The fountain-that, onee struek, must flow for ever-

Will hide and waste in silence. When the smile Steals to her pallid lip again, and spring IVakens the buds above thee, we will eome, And, standing by thy music-haunted grave, Look on each other eheerfully, and say:A child that we have loved is gone to heaven, dud by this gate of flowers she pass'd away!

\section{THE QUEEN OF THE GARDEN}

\section{BY MLOORE.}

If Jove would give the leafy bowere

A queen for all their world of flowers, The Rose would be the ehoiee of Jove And reign the queen of every grove. Sweetest ehild of weeping morning. Gem, the vest of earth adorning, Eye of flowerets, glow of lawny, Bud of beauty, nursed by dawns; Soft the soul of love it breathes; Cypria's brow with magic wreathes; And to the zephyr's warm earesses Diffuses all its verdant tresses, 'Iill, glowing with the wanton's play, It 'jlushes a diviner ray ! 


\section{THE COWSLIP.}

UNFOLDING to the breeze of May, 'The Cowslip greets the vernal ray; The topaz and the ruby gem, Her hlossom's simple diadem ; And, as the dew-drops gently fall, They tip with pearls her coronal.

In prineely halls and courts of kinge Its lustrious ray the diamond flings; Yet few of those who see its beam, Amid the toreh-light's dazzling gleam, As bright as though a meteor shone, Can call the costly prize theil own.

But gems of every form and hue Are gl tlering here in morning dew; Jewels that all alike may share As freely as the common air; No niggrard hand, or jealous cye, Protects them from thc passer by.

Man to his brother shuts his heart, And Scierce aets a miser's part; But Naturc, with a liberal hand, Flings wide her stores o'er sea and land If gold she gives, not single grains Are scatter'd far across the plains ; But lo, the desert stleans are roll'd $\checkmark$ 'er preeinus beds of virgin gold. If flowel's she offers, wreaths arc givon, As countless as the stars of heaven: 
Or music - 'tis no feeble note She bids along the valleys float; Ten thousand nameless melodies In one full ehorus swell the breezo.

$\mathrm{Oh}$, art is but a scanty rill That genial seasons scarcely fill. Bat nature needs no tide's return To fill afresh ker flowing urn : She gathers all her rich supplies Where never-failing waters rise."

\section{TU THE ROUND-LEAFED SUNDEW.}

$\mathrm{Br}$ the lone fountain's secret bed, Where human footsteps rarely tread, 'Mid the wild moor of silent glen, The Sundew blooms unseen by men; Spreads there her leaf of rosy hue, A chalice for the morning dew, And, ere the summer's sun can rise. Drinks the pure waters of the skies. Wouldst thou that thy lot were given. Thus to receive the dews of heaven, With heart prepared, like this meek flower ? Come, then, and hail the dawning hour; So shall a blessing from on high, Pure as the rain of summer's sky, 
Unsullied as the morning dew,

Deseend, and all thy soul imbue.

Yes ! like the blossoms of the waste

Would we the sky-born waters taste,

'T'o the High Fountain's saered spring

'The elaliee let us humbly bring :

So shall we find the streams of heaven

'T'o him who seeks are freely given;

'The morning and the evening dew

Shall still our failing strength renew.

\section{A CYPRESS LEAF,}

FOR TIIE GRAVE OF A DEAR ONE.

T'rn feelings I have felt have died away,

'The love that was my lamp death's dews have queneh'd ;

'The faith whieh, through life's ills, ne'er knew deeay,

Hath in the chill showers of the grave been dreneh'd ;

The hopes that buoyed my spirit 'mid the spray Of life's wild ocean, one by one are wreneh'dCruelly wrench'd away, - and I am now A solitary leaf on a rent bough !

The link that knit me to mankind is snapp'dBriefly it bound me to a eallous world; 
T'he fortress of my comfort hath been sapp'd--

Where are Joy's banners, lightsomely unfurl'd, 'That graced the battlements? In vapor wrapp'd

In the dense smoke of stifled breath upcurl'd, They drop in tatters-forming now a pall For the sad mummy-heart that drips with gall.

I have not now of broken troth to wail,

I have not now to speak of friendship broken;

Uf Death and Death's wild triumphs is my tale--

Of friendship faithful, and of love's last token,

A ring ! - whose holy motto ne'er shall fail

To rouse such sorrow as may ne'er be spoken Ihat pictured Dove and Branch-those words, 'La Paix!'

0 direful mockery!) wear my heart away!*

Peace?'-Peace! alas, there is no peace for me. It rests with thee, beloved one! in the grave' Yet, when I seareh the eells of Memory.

Where silently the subterranean wave Of buried hope glides on, a thought of theeLike sunshine on the hermit's darkened cavetreals gently o'er my spirit, whispering sweet Of realms beyond the tomb. where we shall meet !

* A melancholy anecdote is attached to these lines; he motto ' $L_{A} P_{A I X}$ ' was engraven on the bequeathed zift of a beloved friend, who, in the bloom of youth "ell a victim to sudden and violer: death in India. 
Our love-how did it spring? In sooth it grew Even as some rare exotic in a clime Unfriendly to its growth: yet rich in hue, Voluptuous in fragrance, as if Time IIad oeen to it all sunlight and soft dew, As if upon its freshness the eold rime of death should urver fall! How came it then Even as the manna fell 'midst famish'd men.

To be snateh'd up in transport! And we fed Upon affection's banquet, that ne'er pall'd Upon the spirit's palate! Friendship slied A light around our bosoms which recall'd The memory of that bard, whose soul was wedWith love surpassing woman's love, ungall'd By selfish doubts - to him, the monarch's son, Brave Jonathan! Like their's, our souls were one

Oh ! long we loved in slence! Neither spake

of that which work'd the thoughtful mines within;-

Thou didst not guess that, sleeping or awake,

My thoughts were full of thee till thought grev sin :

For it is sin of earthly things to make

Our idols! and I never hoped to win 'Thy eoveted affection; but for me, Thy heart was als s yearring eilently! 
I was the lirst to spcak-and words there were, Wild words, that painted fond affection's course ;-.

O! what indeed will erring tongues not dare,

Vhen conqucring Feeling prompts! Like winds that force

I'rom wind-harps mystic sounds, the lips declare, Thoughts that are often follow'd by remorse ; For passion hath a potency that breaks Each puny bulwark callous Rcason makes !

But our's was Fricndship's purest worship-pure, Altho' that worship bowed at earthly shrines,

Alas! that hearts on altars insecure

Should sacrifice their all of bliss! There twines

O'er mankind's sweetest hopes corruption sure, 'To blast thcir beauty e'en whilst most it shines!-

"Tis but to teach us there are worlds above, "Where Hope fruition fonds in endless I,ove! 


\section{TVILD FLOWERS.}

BY JOHN KEATS.

I stjob tiptoe upon a little hill;

The air was cooling, and so very still,

That the sweet buds which with a modost pride

Fell droopingly in slanting curve aside,

Their scanty-leaved and finely tapering stems

Had not yet lost their starry diadems,

Caught from the early sobbings of the morn.

' $T$ 'he clouds were pure and white as flocks new shorn,

And fresh from the clear brook; sweetly they slept

On the blue fields of heaven, and then there crept

A little noiseless noise among the leaves, Born of the very sigh that silence heaves; For not the faintest motion could be seen Of all the shades shat slanted o'er $n=$ greel. There was wide wandering for the greediesi eye. To peer about upon variety ; Far round the horizon's crystal air to skim, And trace the dwindled edgings of its brim; To picture out the quaint and curious bending Uf a fresh woodland alley never-ending : Or by the bowery cleíts and leafy shelves, Guess where the janty streams refresh them. selves. 
1 gazed awhile, and felt as light and free As though the fanning wings of Mercury Had play'd upon my licels : I was light-hearted, And many pleasures to my vision started; So I straightway bcgan to pluck a posy Of luxuries bright, milky, soft and rosy. A bush of May-flowers with the bees about them; $A h$, sure no tasteful nook could be without them; And let a lush laburnum oversweep them, And let long grass grow round the roots, to keep them

Noist, cool and green; and shade the violets, That thcy may bind the moss in leafy nets. A filbcrt edge with wild-brier overtwined, And clumps of woodbine taking the soft wind Upon their summer thrones; there too should be The frequent chequcr of a youngling tree, That with a score of bright-green brethren shoots From the quaint mossiness of aged roots : Round which is heard a spring head of clear waters,

Prattling so wildly of its lovely daughters, 'I'he spreading bluc-bells : it may haply mourn That such fair clusters should be rudely torn From their fresh beds, and scatter'd thoughtlessiy By infant hands left on the patls to die. Open afresh your round of starry folds, Ye ardent marigolds!

Dry up the moisture from your go!den lide, For great Apollo bids 
'I'hat in these days your praises should be sung On many harps, which he has lately strung; And when again your dowiness he kisses, 'Iell him, I have you in my world of blisses: So haply wren I rove in some far vale, His mighty voice may eome upen the gale.

Here are sweet-peas, on tiptoe for a flight: IVith wings of gentle flush o'er delicate white. And taper fingers eatching at all things, 'To bind them all about with tiny rings. What next? a turf of evening primroses, O'er which the mind may hover till it dozes; O'er which it well might take a pleasant sleer, But that 'tis ever startled by the leap Of huds into ripe flowers.

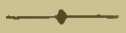 \\ THE JASMINE.}

\section{BY MOORE.}

"IW As midnight-througl the lattiee wreath'd With woudbine, many a perfume breathed From plants that wake when others sleep; From timid jasmine buds that keep Their odour to themsclves all day; But when the sunlight dics away, Let the delicious secret out 'I'o every breeze that roams about. 
THE POETRY OF FLOWERS.

\section{'IO PRIMROSES}

FILIED WITI MORNING DER:

BY IIERICK.

W нг de ye weep, sweet babes? Can tea: Špeak grief in you,

Who were but born

Just as the modest morn

'T'eem'd her refreshing dew !

Alas! ye have not known that shower

That mars a flower ;

Nor felt the unkind

Breath of a blasting wind;

Nor are ye worn with years ;

Or warp'd as we,

Who think it strange to see

Such protty flowers, like to orphans young,

Speaking by tears before ye have a tongue.

Epeak, whimpering younglings, and make knowa

The reason why

Ye droop and weep.

Is it for want of sleep,

Or childish lullaby?

Or that ye have not seen as yet

'The violet?

Or brought a kiss

From at sweetheart to this! 
No, no ; this sorrow shown

By your tears shed,

Would have this leeiure read:

That things of greatest, so of meanest w rrth, Conceived with grief are, and with tears brougas forth.

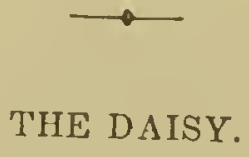

BY JOHN MASON GOOD.

Not worlds on worlds, in phalanx deep, Need we to prove that God is here; The daisy, fresh from winter's sleep, Tells of His hand in lines as clear.

fror who but he who arch'd the skies, And pour'd the day-spring's living fine Wondrous alike in all He tries, Could rear the daisy's purple bud;

Mould its green cup, its wiry stem, Its fringed border nicely spiñ, And cut the gold-embossed gem That, set in silver, gleams within; 
And fling it unrcstrain'd and free, O'cr hill, and dale, and desort sod, That man, where'er he walks, may see, At cvery step, the stamp of God?

\section{FROM METASTASIO.}

The married are compared by the poet to the young Rose., which the lover places in the bosom of his mistress, first stripped of thorns.

Thou virgin Rose! whose opening leaves so taur, The dawn has nourish'd with her balmy dews; While softest whispers of the rnorning air Call'd forth the blushes of thy vermeil hues;

That cautious hand, which cropt thy youthful pride,

Transplants thy honours, where from hurt securc,

Stript of each thorn offensive to thy side, Thy nobler part alone shall bloom maturc.

Thus thou, a flowcr, excmpt from change of skies,

By storms and torrents unassail'd shall riso, And scorn the winter colds, and summer heats; A guard more faithful then thy growth shall tena,

By whom thou mayst in tranquil union blend Eternal beautics with e'en al awcets. 


\section{THE LII, Y. \\ J II . IW I F F E N .}

Look on that flower-the daughter of the vale 'The Medieean statue of the shade!

Her limbs of modest beauty, aspeet pale, Are but by her ambrosial breath betray'd.

'I'here, half in elegant relief display'd, She standetl to our gaze, half-shrinking shuns;

Folding her green searf like a bashful maid Around, to screen her from her suitor suns,

Not all her many sweets she lavisheth at onee.

Loek'd in the twilight of depending boughs,

Where night and day eommingle, she doth shoot, Where nightingales repeat their marriage vows;

First by retiring, wins our eurious foot, Then eharms us by her loveliness to suit

Our contemplation to her lovely lot;

Her gloom, leaf, blossom, fragranee form dispute

Which shall attraet most belgards to the spot, And loveliest her array who fain would rest un sought.

Ier gloom, the aisle of heavenly solitude;

IIer flower, the vestal nun who there abideth;

IIer breath, that of eelestials meelsly woo'd

From heaven; her leaf, the holy veil whieb hidetlı;

Her form, the shrine where purity resideth ; 
Spring's darling, nature's pride, the sylvan's queen-

'l'o her at eve onamour'd Zephyr glideth, Trembling, she bids him waft aside her screen, And to his kisses wakes-the Flora of the scene.

\section{$\rightarrow$ \\ THE NARCISSUS. \\ BY GiY.}

Here young Narcissus o'cr the fountain stood, And view'd his image in the crystal flood; The crystal flood reflccts his lovely charms, And the pleased image strives to meet his arms. No nymph his inexpcrienced breast subdued, Echo in vain the flying boy pursued. Himself alone, the foolish youth admires, And with fond look the smiling shade desires; O'er the smooth lake with fruitless tears he grieves ;

His spreading fingers shoot in verdant leaves: 'Through his pale veins green sap now gently flows, And in a short-lived flower his beauty blows. Let vain Narcissus warn each femalc breast, That beauty's but a transient good at best; Like flowers it withers with th' advancing year, And ogc like winter robs the blooming fair. 


\section{A SONG OF 'THE ROSE.}

BY MRS. HEMANS.

Rose! what dost thou here?

Bridal, royal rose?

How, 'midst grief and fear,

Canst thou thus disclose

That fervid hue of love which to thy heart.leat glows?

Rose! too much array'd

For triumplaal hours,

Look'st thou through the shade

Of these mortal bowers,

Not to disturb my soul, thou crown'd one of all flowers!

As an eagle soaring

Through a sunny sky,

As a clarion pouring

Notes of victory,

So dost thou kindle thoughts, for earthiy life too high -

Thoughts of rapture, flushing Youthful poet's cheek,

Thoughts of glory rushing

Forth in song to break,

But finding the spring-tide of rapid song too weak 
Yet, oh! festal rose,

I have seen thee lying

In thy bright repose

Pillow'd with the dying,

Thy rrimson by the life's quick blood was flyirig,

Summer, hope, and love

O'er that bed of pain,

Meet in thee, yet wove

Too, too frail a claim

In its embracing links the lovely to detain.

Smilest thou, gorgeous flower ?-

$\mathrm{O}$ ! within the spells

Of thy beauty's power

Something dimly dwells,

At variance with a world of sorzows and farewelle.

All the soul forth flowing

In that rich perfume,

All the proud life glowing

In that radiant bloom,

Have they no place but here, beneath th' o'ershadowing tomb?

Crown'st thou but the daughters

Of our tearful race?-

Heaven's own purest waters

Well might bear the trace

of thy consummate form, melting to softer grace. 
Will that clime enfold thee

With immortal air?

Shall we not behold thee

Bright and deathless there?

In spirit-lustre clothed, transcendent y more fair I

Yes ! my fancy sees thee In that light disclose,

And its dream thus frees thee

From the mist of woes,

Darkening thine earthly bowers, 0 bridal, roy al rose.

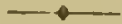 \\ THE ROSE.}

FROM BEAUMONT AND FLETCHER.

OF all flowers.

Methinks a rose is best ......

It is the very emblem of a maid;

For when the west wind courts her gently,

How modestly she blows, and paints the sur:

With her chaste bluslies! When the north comoo near her,

Rucle and impatient, then, like chastity, She locks her beauties in her bud again, And leaves hitn to base briers. 


\section{THE CAPTIVE AND THE FLOWERS.}

FROM THE GERIAN OF GOETIXE.

\section{CAPTIVE.}

A FLower that's wondrous fair, I know, My bosoin holds it dear;

To seek that flower I long to go,

But am imprison'd here.

'Tis no light grief oppresses me ; For in the days my steps were free,

I had it always near.

Far round the tower I send mine eye

The tower so steep and tall;

But nowhere ean the flower desery

From this high eastle wall;

And him who'll bring me my desire,

Or be he knight, or be he squire,

My dearest friend I'll eall.

ROSE.

My blossoms near thee I disclose, And hear thy wretched plight; Thou meanest me, no doubt, the rose Thou noble, hapless knight.

A lofty mind in thee is seen, And in thy hosom reigns the queon Of flowers as is her right. 


\section{CAPTIVE.}

Thy crimson tud I duly prize In outer robe of green;

For this thou'rt dear in maiden's eyea,

As gold and jewels sheen. Thy wreath adorns the fairest brow, And yet the flower-it is not thou, Whom my still wishes mean.

\section{LILV.}

The little rose has cause for pride, And upwards aye will soar; Yet am I held by many a bride The rose's wreath before.

And beats thy bosom faithfully, And art thou true, and pure as I, Thou'lt prize the lily more.

CAPTIVE.

I call myself both chaste and pure, And pure from passions low ;

And yet these walls my limbs immuro In loneliness and woe.

Though thou dost seem, in white array Like many a pure and beauteous maid, One dearer thing I know. PINk.

And dearer I, the pink, must be, And me thou sure dost choose, Or else the gard'ner ne'er for mo Such watchful eare would use: 


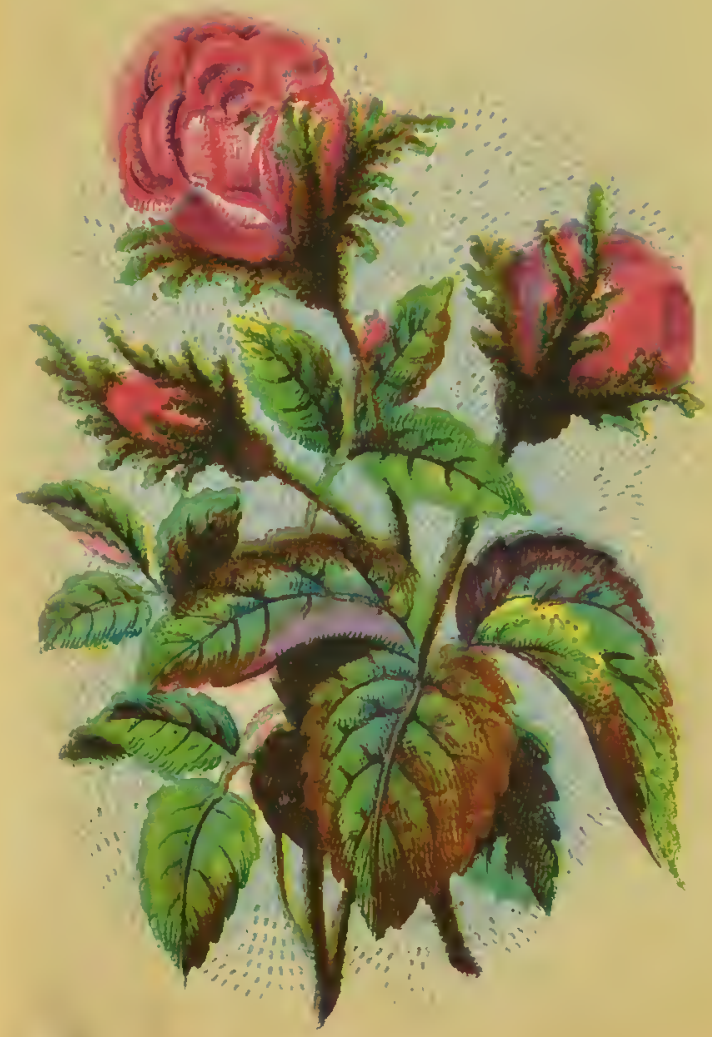



A crowd of lcaves enriching bloom!

And mine through life the sweet pcrfume,

And all the thousand hues.

CAPTIVE.

The pink can no one justly slight, The gard'ner's favourite flower; He sets it now beneath the light. Now shields it from its powcr. Yet 'tis not pomp, who o'er the rest In splendour shines, can make me blest; It is a still, small flower.

\section{VIOLET.}

I stand coneeal'd, and bending low, And do not love to speak; Yet will I, as 'tis fitting now, My wonted silenec break. For if 'tis I, thou gallant man, Thy heart desires, thine, if I ean, My perfumes all I'll make.

CAPTIVE.

The violet I esteem indecd, So modest and so kind; Its fragrance sweet yet more I need, To soothe mine anguish'd mind. To you the truth will I confess; Here, 'mid this rocky drearincss, My love I ne'er shall find. 
The truest wife by yonder brook Will roain the mournful day, And hither east the anxious look,

Long as immured I stay.

Whene'er she breaks a small blue flower, And says, "Folget me not!" the power

I feel, though far away.

Yes, e'en though far, I feel its might,

For true love joins us twain,

And therefore 'mid the dungeon's night

I still in life remain.

And sinks my heart at my hard lot, I but exelaim, "Forget me not!"

And straight new life regain.

\section{$\longrightarrow$ \\ FRAGMENT.}

BY SIR WALTER SCOTT.

Ars well the lonely infant knew Reeesses where the wall-flower grew And honeysuekle loved to erawl Up the low erag and ruin'd wall. I deem'd such nooks the sweetest shade 'The sun in all his round survey'd, And still I thought that sliatter'd tower The mightiest work of human power. 
THE POETRY OF FLOWERS.

\section{THE VIOLET:*}

$3 \mathbf{Y}$ G. J. C L A R K E.

When April's warmth unlocks the clod, Soften'd by gentle showers, The violet pierces through the sod, And blossoms, first of flowers ; So may I give my heart to GOD

In childhood's early hours.

Some plants, in gardens only found, Are raised with pains and care :

GoD scatters violets all around,

They blossom every where; Thus may my love to all abound, And all my fragrance share.

Some scentless flowers stand straight and high.

With pride and haughtiness :

But violets perfume land and sky,

Although they promise less.

Jet me, with all liumility,

Do more than I profess.

- Written for a little girl to speak on May-day, to -) $\theta$ sharacter of the Violet. 
Sweet flower, be thou a type to ine

Of blamcless joy and mirth,

Of widely-scatter'd sympathy,

Embracing all Goo's earth-

of early-blooming picty,

And unpretending worth.

\section{SEND THE LILIES GIVEN TC ME}

BY BYRON.

I SEND the lilies given to me;

Though, long before thy hand they touch,

I know that they must wither'u be ;

But yet reject them not as such:

For I have cherish'd them as dear,

Because they yet may meet thine eye,

and guide thy soul to mine even here,

When thou behold'st them drooping nig 'y.

And know'st them gather' $d$ by the Rhine, And offer'd from my heart to thine!

The river nobly foams and flows,

The charm of this enchanted ground,

And all its thousand turns disclose

Some fresher beauty varying round; 
The haughtiest breast its wish might bound, 'Through life to dwcll delighted here; Nor eould on eartn a spot be found 'I'o nature and to me so dear.

Could thy dear eyes, in following mine, Still sweeten more these banks of Rhine !

\section{FADED FLOWERS.}

BY MRS. SARAH IIELEN WHITAIN.

Remembraneers of happiness! to me Ye bring sweet thoughts of the year's purple prime,

IVild, mingling melodies of bird and bee

That pour on summer winds their silvery chime ; And of rieh ineense, burdening all the air,

From flowers that by the sunny garden wall 3loom'd at your side,-nursed into beauty there By dews and silent showers; but these to all Ye bring. Oh! sweeter far than these the spell Shrined in those fairy urns for me alone, For me a eharm sleeps in each honey'd eell Whose power ean eall baek hours of rapture flown,

ro the sad hear: sweet memories restore,

Tones, looks, and words of love that may re. tirn no inore. 


\section{TO DAFFODILS.}

BY GEORGE HERRICE.

Fair daffodils, we weep to see

You haste away so soon;

As yet, the early-rising sun

Has not attain'd its noon. Stay, stay,

Until the hastening day

ITas run

But to the even song;

And having pray'd together, we

Will go with you along.

We have short time to stay as you.

We have as short a spring; As quick a growth to meet decay,

As you or any thing.

We die,

As your hours do, and d: $y$

Away,

Like to the summer's rain-

Or as the pearls of morning's dew.

Ne'er to be fourd argain. 


\section{WHITE ROSES.}

\section{BY SARAH LOUISA P. SMITH.}

T'неу were gather'd for a bridal!

I knew it by their hue:

Fair as the summer moonlight

Upon the sleeping dew.

From their fair and fairy sisters

They were borne, without a sigh,

For one remember'd evening

'To blossom and to die.

They were gather'd for a bridal!

And fasten'd in a wreath;

But purer were the roses

Than the heart that lay beneath;

Yet the beaming eye was lovely, And the coral lip was fair, And the gazer look'd and ask'd not For the secret hidden there.

They were gather'd for a bridal ' Where a thousand torehes glisten'd, When the holy words were spoken, And the false and faithless listen'd And answered to the vow

Which another heart had taken,

Yet he was present then-

The once loved, the forsaken. 
They were gather'd for a bridal! And now, now they are dying, And young J,ove at the altar Of broken faith is sighing. Their summer life was stainless, And not like her's who wore them They are faded, and the farewell Of beauty lingers o'er them!

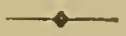

\section{THE FURZE.}

'Min scatter'd foliage, pale and sere, Thy kind floweret cheers the gloom; And offers to the waning year The tribute of its golden bloom.

Beneath November's clouded sky, In chill December's stormy hours, Thy blossom neets the trave" er's eye, Gay as the buds of summer bowers.

Flower of the dark and wintry day! Emblem of friendship! thee I hail! Blooming when others fade away, And brightest when their hues grow pals 


\section{NIGIT-BLOOMING FLOWERS.}

\section{BY JULIET H. LEWIS.}

Flin buds! I've wander'd day by day 'I'o this sequester'd spot,

'That I might catch your earliest smiles, And yet, you open not. The morning mists are scattered now,

No cloud is in the sky,

The sun, like a benignant king,

Smiles from his throne on high ;

While birds, in gushing melody,

Are offering homage up ;

And sistcr flowers, beneath his gaze,

Ope wide each fragilc cup.

Vhy shut you then your incense in,

And hide your loveliness,

As though no one might share your jo

Bcneath the sun's caress?

Now wake you, 'tis the sunset liour,

The day-king has gone down;

Yet still, above the mountain's top,

Is seen his brilliant crown;

A wake you ! if his gleaming gems,

His bands of glittering gold,

His glorious, life-like radianne

neparting, you'd kehold. 
'The river's touch'd with glowing lighi, And rolls, a crimson flood; While heaven's blush has lent its liues Unto the leafy wood.

Still, are you folded to your dreams?

Bright must those visions be, If they surpass the gorgeousness Of evening's pageantry!

Good night ! the stars are gemming heavers And seem like angel's eyes, Resuming now their silent watch Within the far-off skies;

They uightly on their burning thrones Like guardian spirits, keep Familiar vigil o'er the world, Wrapt in its solemn sleep; And tenderly they gaze on us, Those ehildren of the air, While every ray they send to us, Some message seems to bear, 'I'hat stirs us to the inmost eore; And we do thrill beneath their beams, And start, and tremble, wildly, like Ambition in his dreams.

Now, lo ! you burst your emerald bonds And ope your languid eyes, And spread your loveliness before Those dwellers of the skies: 
W nile incense, from your grateful hearts, Like prayer ascends to heaven; And kindly dew, and starry light, Are answering blessings given. "Ask and ye shall receive," you seem To whisper to my heart,

And move me in your worshipping To take an active part. Sweet teachers! 'tis an hour for prayer, When hush'd are sounds of mirth, And slumber rests his balmy wing Upon the weary earth: When all the ties that bind the soul To worldliness, are rivenThen heart-felt prayers, like loosen' $\mathfrak{d}$ birds Will wing their way to heaven. 


\title{
THE FLOWER-GARDEN
}

\author{
BY R. M. MUL,NES.
}

O IEnsive Sister! thy tear-darken'd gaze I understand, whene'er thou look'st upon 'The Garden's gilded green and colour'd blaze, The gay society of flowers and sun.

Thou thinkest of the withering that must come, 'The quenching of this radiance all around, The hastening change in Nature's merriest home, The future blackness of the orphan'd ground.

Thou thinkest too of those more precious blooms The firstling honours of thy Life's fresh field, I'he childly feelings that have all their tombs, The hopes of youth that now no odours yield:

3till many a blessed sense, in living glee,

Waves its bright form to glorify thy breast, But this fair scene's perverse morality Tells thee, they all will perish like the rest:

Yet pluck them, hinrt them not; whate'er betides Touch not with wilful force those flowers o thine,-

Let death receive them, his inviolate brides, 'They' are the destined vestals of bis shrine. 
And if those children of the insensate earth

Go down in peace to a prolific grave,If Nature raises in continuous birth

The plant whose present grace she will not save,-

So some deep-grounded root or visible seed,

When these heart-blossons fade, may still remain,

In a new season of thy being, decreed

To rise to light and loveliness again.

\section{THE FRAGRANT AIR.FLOWER.}

\section{BY T. K. HERVEY.}

Men say there is a gentle flower, 'That, born beneath an eastern sky,

Without the gift of sun or shower,

Gives out its precious sigh .

That-with affection-sweetly dwells

Beneath the Indian's stately doom

Or freely throws its fragrant spells

A round his lowiy lome,-

Fed only by that sacred air

That, as a spirit, hovers there : 
And thou art like that fairy thing, Though gifted with a eolder sky, With seent and bloom, too pure to fling Before the passer by;

Who, with the star-flowers of thine eyea,

Couldst brighten still the brightest lot,

Or, with thy fond and fragrant sighs,

Make rich the poor man's eot !An English Ruth,-in good or ill,

To follow wheresoe'er we roam,

And hang thy preeious garlands, stil?,

Amid the breath of home!

-My weary heart! my weary heart '

It is a pleasant thing

'I'o wander from the erowd apart,

When faint, and chill' $d$, and eold thou ir

And fold thy restless wing,

Beside the sweet and quiet streams

Where grow life's lily bells, -

And peace-that feeds on happy ireams

And utters music,-dwells--

And love, beside the gushing springs,

Like some young Naiad, sits and singo"

To leave awhile the barren height,

Where thou, too long, liast striven

As if the spirit's upvourd flight

Had been the path to heaven 
Ard musing by love's haunted rill, Earth's "river of the blest," To see how siveetly heaven still,

Is mirror'd on its breast, And feel thou, there, art nearer far To that bright land of sun and star !

\section{THE ALPINE FLOWERS.}

BY MRS. SIGOURNEX.

Mzex dwellers 'mid yon terror-stricken eliffs ! With brows so pure, and incense-breathing lips, Whence are ye?-Did some white-wing'd mes senger

On Mercy's missions trust your timid germ To the eold eradle of eternal snows?

Or, breathing on the callous icicles,

Bid them with tear-drops nurse ye?-

- Tree nor shrub

Dare that drear atmosphere: no polar pine Uprears a veteran front; yet there ye stand, Leaning your cheeks against the thiek-ribb'd iee, And looking up with brilliant eyes to Him Who bids you bloom unblanch'd amid the waste Of desolation. Man, whs, panting, toils $D$ er slippery steeps. or trembling treads the verg? 
Of yawning gulfs, o'er which the headlong plunge Is to eternity, looks shuddering up, And marks ye in your placid lovelinessFearlcss, yet frail--and, clasping his chill hands, Biesses your pencill'd beauty. 'Mid the pomp Of mountain summits rushing on the sky, And chaining the rapt soul in breathless awe, He bows to bind you drooping to his breast, Inhales your spirit from the frost-wing'd gale. And freer dreams of heaven.

\section{THE MISTLET OE.}

\section{BY BARRY CORNIVALL}

Ir FEN winte: nights grow long,

And winds without blow cold,

We sit in a ring round the warm wood-trre,

And listen to stories old!

And we try to look grave (as maids should be,; When the men bring in boughis of the laurel-tree $O$. the Laurel, the evergreen tree! The Poets have laurels-and why not we?

How pleasant, when niglut falls down, And hides the wintry sun, To see them come in to the blazing fire, And know that thcir work is done; 
While many bring in, with a laugh or rngme, Green branches of holly for Christmas time!

$O$ the Holly, the bright green Holly, It tells (like a tongue) that the times are jolly.

Sometimes-in our grave-house,

Observe, this happeneth not; But, at times, the evergreen laurel boughs And the holly are all forgot! And then! what then? why, the men laugh low, And hang up a branch of - the Mistletoe! Oh, brave is the Laurel! and brave is the Holly! But the Mistletoe banisheth melancholy! Alh, noody knows, nor ever shall know What is ilone-unier the IVstletos! 


\section{T'O THE PRIMROSE.}

\section{BY BIDLAKE。}

PAJE visitant of balmy spring,

Joy of the new-born year,

That bidd'st young hope new-plume his wing

Soon as thy buds appear:

While o'er the incense-breathing sky

'The tepid hours first dare to fly,

And vainly woo the chilling breeze

That, bred in winter's frozen lap.

Still-struggung chams the lingermng sar

Within the widow'd trepe.

Remote from towns, thy transient lite

Is spent in skies more pure;

The suburb smoke, the seat of strife,

Thou canst but ill endure.

Coy rustic! thou art blooming found

Where artless naturc's charms abound,

Sweet neighbour of the chanter ril?;

Well pleased to sip the silvery tide,

Or nodding o'er the fountain's side,

Self-gazing, look thy fill; 
Or, on the diugle's shadowy steep, 'The gaudy furze beneath,

'T'hy modest beauties sweetly peep, 'Thy ehaster odours breathe.

From luxury we turn aside,

From wealth and ostentatious pride.

With many an emblematic thorn, 'Thy humbler mien well pleased to meet; Like competence in blest retreat,

'Thy smiles the spring adorn.

What though thou boast no splendid hue

Of Flora's prouder race?

To me more fair art thou to view,

In all thy simple grace:

Thine innocenee and beauty meek, More like my Celestina's cheek,

Where all the modest virtues play; Expression beaming from her eye, In cherub smiles of chastity,

With mild and temper'd ray.

Yet Ireasures lurk within thy lips

l'o glad the spoiler bee, Who not with idle errand sips,

Or wanton vagrancy.

Ah! blest is he who temperance tres, Simplicity above disguise. 
And shuns the falser gloss of art; 'T'is he extracts a bliss refined, Congenial to the virtuous mind, FThe tender feeling heart.

Thy smiles young innocence invite,

What tine thy lids awake,

In shadowy lane to taste delight,

Or mazy tangled brake. 'The infant troop of rosy hue, And gay with health I seem to view,

While pleasure lights their laughing eye With little hands a wreatl combine, Their fugitive delights entwine, And boast their fragrant prize.

Ah ! happy breasts ! unknown ro pain

I would not spoil your joys; Nor vainly teach you to complain

Of life's delusive toys.

Be jocund still, still sport and smile, Nor dream of woe or future guile;

For soon shall ye awaken'd find 'Ihe joys of life's sad thorny way, But fading flowerets of a day Cut down by every wind. 


\section{THE VIOLET.}

\section{BY BARRY CORNWALL.}

I Love all things the seasons bring, All buds that start, all birds that siug, All leaves, from white to jet ;

All the sweet words that Summer sends, When she recalls her flowery friends, But ehief-the Violet !

I love, how much I love the rose,

On whose soft lips the South-wind blows In pretty amorous threat; The lily paler than the moon, The odorous wondrous world of June, Yet more-the Violet!

She comes-the first, the fairest thing That Heaven upon the earth doth fling,

Ere Winter's star has set; She dwells behind her leafy screen. And gives, as angels give, unseen: So, love-the Violet!

What modest thoughts the Violet teaehes, What graeious boons the Violet preaehes,

Bright maiden, ne'er forget! But learn, and love, and so depart, And sing thou, with thy wiser heart,

"Long live the Vialet!" 


\section{FADED FLOWERS.}

\section{BY MISS JEIVSBURY.}

FADED flowers,

Sweet faded flowers,

Beauty and death

Have ruled your hours;

Ye woke in bloom but a morn ago,

And now are your blossoms in dust laid low.

But yesterday

With the breeze ye strove,

in the play of life,

In the pride of love ;

To and fro swung each radiant head,

That now is drooping, and pale, and dead?

Delicate flower,

With the pearl-white bells,

No more shall dew-drop

Sleep in thy cells!

No more, rich rose, on thy heaving breast, T'he honey-bee fold his wings to rest !

Fair myrtle-tree,

'T'hy' blossoms lie low,

But green above them

Thy branehes grow ;

Like a buried love, or a vanish'd joy, link'd unto memories none destroy. 


\section{Faded flowers, Sweet faded flowers- \\ Fair frail records Of Eden's bowers ;}

In a world where sorrow and wrong bear away, Why should ye linger ?-Away ! away !

What were the emblems

Pride to stain,

Might ye your glorious

Crowns retain?

And what for the young heart, bow'd with grief, Were the rose ne'er seen with a wither'd leaf?

Ye bloom to tell us

What once hath been;

What yet shall in heaven

Again be seen ;

Ye die, that man in his strength may learn,

How vain the hopes in his heart that burn.
Many in form,
And bright in hue!
I know your fate,
But the earth to strew,

And my soul flies on to immortal bowers, Where the heart and the rose are not faded fiowers. 


\section{THE R OSES.}

\section{BT BOWRING.}

I SAW them once blowing,

While morning was glowing;

But now are their wither'd leaves strew'd o'er tho ground,

For tempests to play on,

For cold worms to prey on,

'T'he shame of the garden that triumphs around.

Their buds which then flourish'd,

With dew-Arops were nourish'd,

Which turn'd into pearls as they fell from on high

Their hues are all banish'd,

'Their fragrance all ranish'd,

Ere evening a shadow has cast from the sky.

I saw, too, whole rares

Of glories and graces

Thus open and blossom, but quickly decay;

And smiling and gladnesa,

In sorrow and sadness,

Ere life reach'd its twilight, fade gimly away.

Joy's light-hearted dances

And melody's glances, 
Are rays of a moment-are dying when boin;

And pleasure's best dower

Is nought but a flower,

A vanishing dew-Irop-a gers of the mor..

The bright eye is clouded,

Its brilliancy shrouded,

Our strength disappears, we are helpless and lone

No reason avails us,

And intellect fails us;

Life's spirit is wasted, and darkness comes on.

\section{T O THE SNOW-D R OP.}

BY BARRY CORNWALL.

PretTy firstling of the ycar !

Herald of the host of flowers,

Hast thou left my cavern drear,

In the hope of summer hours?

Back unto my earthen bowers!

Back to thy warm world below,

Till the strength of suns and shower

Quell the now relentless snow!

Art still here?-Alive? and blithe?

Though the stormy night hath fled, And the Frost hath pass'd his scythe

O'er hy small unshelter'd head, 
Ah!-somc lie arnid the dead, (Many a giant stubborn tree,Many a plant, its spirits shed,) That wcre bctter nursed than thee'

What hath shved thee? 'Thou wast not 'Gainst the arrowy winter furr' $\mathrm{d},-$-Arn'd in scale-but all forgot

When the frozen winds were stirr'd.

Nature, who doth clothe the bird, Should have hid thee in the earth,

Till the cuckoo's song was heard, And the Spring let loose her mirth.

Nature-deep and mystic word, Mighty mother, still unknown! Thou didst sure the Snow-drop gird With an arnour all thine own !

Thou, who sent'st it forth alone To the cold and sullen season, (Like a tlought at random thrown,) Sent it thus for some grave reason!

If 'twere but to pierce the mind

With a single gentle thought, Who shall deem thee harsh or blind ?

Who that thou hast vainly wrought $f$,

Hoard the gentle virtuc caught From the Snow-drop-reader wise !

Good is good, wherever taught, On the ground or in the skies 
THE POETRY OF ELOWERS.

\section{TO THE JESSA M I E.}

\section{BY MISS TANE TAYLOR.}

SwEET jessamine, long may thy elegant flower

Breathe fragrance and solace for me:

And long thy green sprigs overshadow the bower

Devoted to friendship and thee.

T'he eye that was dazzled where lilies and roses

Their brilliant assemblage display'd,

With grateful delight on thy verdure reposes,

A tranquil and delieate shade.

But ah! what dejection that foliage expresses,

Which pensively droops on her breast!

The dew of the evening has laden her tresses,

And stands like a tear on her erest.

l'll watch by thy side through the gloom of the night

Impatient till morning appears:

No eharm ean awaken this heart to delight,

My jessamine, while thou art in tears.

But soon will the shadows of night be withdrawn.

Whieh ever in mercy are given;

And thou shalt be eheer'd by the light of the morn

A yd fanu'd by the breezes of heaven. 
And still máy thy tranquil and delicate shade Yield fragiance and solace to me; For though all the flowers in my garden should fade,

My heart will repose upon thce.

\section{$\longrightarrow$ \\ ON A FADED VIOLET.}

BY SHELI,EY.

THE odour from the flower is gone Which, like thy kisses, breathed on me;

The colour from the flower is flown, Which glow'd of thee, and only thee ?

1 shrivel'd, lifelcss, vacant form, It lies on my abandon'd breast, Ind mocks the heart, which yet is warm, With cold and silent rest.

1 wcep,-my tcars revive it not!

I sigh,-it breathes no niorc on me;

its mute and uncomplaining lot

Is such as mine should bc. 
THE POETRX CE FLCWEXS.

\section{DAWN, GFNTLE FLOWER.}

\section{BY BARRY CORNWALL.}

DAws, gentle flower;

From the morning eartl! We will gaze and wonder At thy wondrous birth :

Bloom, gentle flower !

Lover of the light,

Sought by wind and shower,

Fondled by the night!

Fade, gentle flower!
All thy white leaves elose $;$

Having shone thy beauty,

Time 'tis for repose.

Die, gentle flower,

In the silent sun !

So-all pangs are over,

All thy tasks are done!

Day hath no more glory,

Though he soars so ligh ;

Thine is all man's story,

Live-and love-and di: : 


\section{THE LILY AND THE ROSE.}

BY COWPER.

T'ire nymph must lose lier female friend If more admired than she-

But where will fierce contention end, If flowers can disagrec?

Within the garden's peaceful scene A ppear'd two lovely foes, Aspiring to the rank of queen, The Lily and the Rose.

The Rose soon redden'd into rage, And swelling with disdain, Appeal'd to many a poet's page To prove her right to reign.

The Lily's height bespoke command, A fair imperial flower;

She seem'd design'd for Flora's hany, The sceptre of her power.

This civil bickering and debate The goddess chanced to hear; And tlew to save, cre yet too late, The $p$ ide of the zarterre. 
"Youra is," she said, "the noblest lue, And yours the statelier mien;

And, till a third surpasses you, Let each be deem'd a queen.'

Thus soothed and reconeiled, both seek The fairest British fair ;

'The seat of empire is her eheek, They reign united there.

\section{$\longrightarrow$ \\ THE VIOLET.}

BY SCOTT.

THE violet in her greenwood bower,

Where birehen boughs with hazels mirgle, May boast herself the fairest flower,

In glen, or eopse, or forest dingle.

'Though fair her gems of azure hue,

Beneath the dew-drop's weight reelining,

I've seen an eye of lovelier blue,

More sweet through watery lustre shining.

The summer sun that dew shall dry,

Ere yet the day be past its morrow:

No longer in my false love's eye

Remain d the tear of parting sorrow. 


\section{IHE DYING GIRL AND FLOWERS}

BEAR them not from grassy dells, Where wild bees have honey-cells, Not from where sweet water-sounds Thrill the greenwood to its bounds; Not to waste their scented breath On the silent room of Death !

Kindred to the breeze they are, And the glow-worm's emerald star, And the bird, whose song is free, And the many-whispering tree: $\mathrm{Oh}$ ! too deep a love, and fain, They would win to earth again.

Spread them not before the eyes, Closing fast on summer skies ! Woo thou not the spirit baek, From its lone and viewless traek, With the bright things whieh have birth Wide o'er all the eolour'd eartls!

With the violet's breath would rise Thoughts too sad for her who dies; From the lily's pearl-eup shed, Dreams too sweet would haunt her bed; Dreams of youth - of spring-time evesMusic-beauty - all she leaves ! 


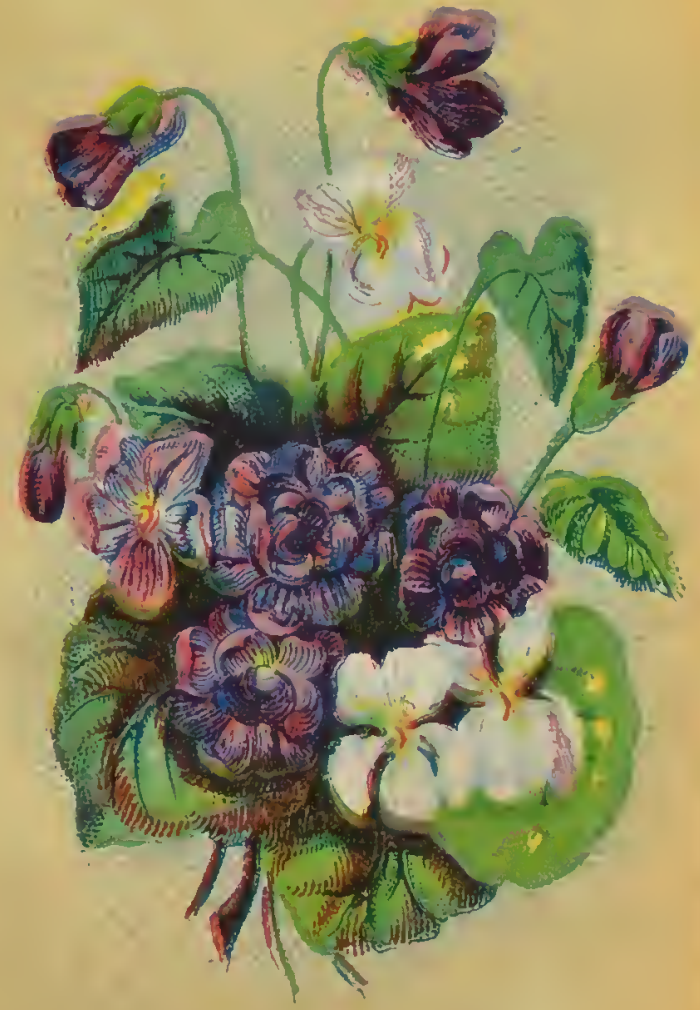


Hush! 'tis thou that dreaming art,

Calmer is her gentle heart.

Yes! o'er fountain, vale, and grove,

Leaf and flower, hath gush'd her love,

But that passion, deep and true,

Knows not of a last adieu.

Types of lovelier forms than these,

In their fragile mould sle sees ;

Shadows of yet richer things,

Born beside inmortal springs,

Into fuller glory wrought,

Kindled by surpassing thought .

Therefore in the lily's leaf

She can read no word of grief;

O'er the woodbine she can dwein,

Murmuring not-Farewell! farewell!

And her dim yet speaking eye,

Greets the violet solemnly.

Therefore, once, and yet again, Strew them o'er her bed of pain;

From her chamber take the gloom,

With a light and flush of bloom:

So should one depart, who goes

Where no death can touch the rose. 


\section{THE NIGH'T.SHADE.}

\section{BY BARRY CORNWALL.}

TrRAD aside from my starry bloom!

I am the nurse who feed the tomb

(The tomb, my child)

With dainties piled,

Until it grows strong as a tempest wild.

Trample not on a virgin flower!

I am the maid of the midnight hour;

I bear sweet sleep

To those who weep,

And lie on their eyelids dark and deep.

Tread not thou on my snaky eyes !

I am the worm that the weary prize,

The Nile's soft asp,

'That they strive to grasp,

And one that a queen has loved to clasp!

Pity me! I am she whom man

Hath hated since ever the world began;

I soothe his brain,

In the night of pain,

But at morning he waketh-and all is vain 


\section{THE LAY OF THE ROSE.}

BY ELIZAEETII B. BARRETT.

"Discordance that can accord ;

And accordance to discord."

The Romaunt of the Ros

A Rose once pass'd within

A garden, April-green,

In her loneness, in her loneness,

And the fairer for that oneness.

A white rose, delicate,

On a tall bough and straight,

Early comer, April comer,

Never waiting for the summer;

Whose pretty gestes did win

South winds to let her it, Iin her loneness, in her loneness. All the fairer for that oneness.

"For if I wait," said she,

"Till times for roses be,

For the musk rose, and the moss rose, Royal red and maidon blush rose, 
"What glory then for me,

In such a company?

Roses plenty, roses plenty, And one nightingale for twenty?

"Nay, let me in," said she,

"Before the rest are free, In my loneness, in my loneness, All the fairer for that oneness.

"For I would lonely stand, Uplifting my white hand, On a mission, on a mission, To declare the coming vision.

"See mine, a holy heart, 'To high ends set apart, All unmated, all unmated, Because so consecrated.

"Upon which lifted sign, What worship will be mine! What addressing, what caressing, What thanks, and praise and blessing "

"A wind-like joy will rush Through every tree and bush, Bending softly in affection, And spontaneous benediction. 
"Insects, that only may

Isive in a sunbright ray,

To my whiteness, to my whiteness

Shall be drawn, as to a brightness.

"And every moth and bee

Shall near me reverently,

Wheeling round me, wheeling o'er mo Coronals of motioned glory.

"I ween the very skies

Will look down in surprise, When low on earth they see me, With my cloudy aspect dreamy.

"E'en nightingales shall flee Their woods for love of me, Singing sadly all the suntide, Never waiting for the moontide!

"Three larks shall leave a cloud

To my whiter beauty vow'd, Singing gladly all the moontide, Never waiting for the suntide."

So praying did she win South winds to let her in, In her loneness, in her loneness, And the fairer for that oneness. 
But out, alas, for her!

No thing did minister

To her praises, to her praises, More than might unto a daisy's.

No tree nor bush was seen

To boast a perfect green, Scarcely having, scarcely laving One leaf broad enow for waving.

The little flies did crawl

Along the southern wall,

I aintly shifing, faintly shifting Wings scarce strong enow for lifting.

The rightingale did please To loiter beyond seas, Guess him in the happy islands, Hearing music from the silence.

The lark too high or low,

Did haply miss her soWith his crest down in the gorses, And his song in the star-courses!

Only the bee, forsooth, Cane in the place of bothDoing honour, doing lonour, To the honey-dews upon her. 
The skies look'd eoldly dowu

As on a royal crown;

Then, drop by drop, at leisure.

Began to rain for pleasure.

Whereat the earth did seem

To waken from a dream, Winter frozen, winter frozen,

Her anguish eyes unelosing.

Said to the rose, "Ha, Snow!

And art thou fallen so?

'Thou who wert enthronćd statelv Along my mountains lately.

"Holla, thou world-wide snow

And art thou wasted so?

With a little bough to eatch thee

And a little bee to wateh thee?"

Poor rose, to be misknown!

Would she had ne'er been blown,

In her loneness, in her loneness,

All the sadder for that oneness.

Some words she tried to say,

Some sigh-ah, well away!

But the passion did o'ereome her, And the feir frail loaves dropp'd from ne: 
Dropp'd fiom her, fair and mute,

Close to a poet's foot, Who beheld them, smiling lowly, As at something sad yet holy:

\section{Said "Verily and thus,}

So chanceth e'er with us, Poets, ringing swectest snatches, While deaf did men kcep the watches

"Saunting to come before

Our own age evcrmore, In a loneness, in a loneness, And the nobler for that oneness.

"But if alone we be Where is our empiry? And if none can reach our stature Who will mate our lofty nature?

"What bell will yield a tone Saving in the air alone? If no brazen clapper bringing, Who can bear the chimêd ringing ?

"What angel but would seem To sensual cyes glent-dim? And without assimilation, Vain is interpenetration! 
"Alas ! what can we do,

The rose and poet too,

Who both antedate our mission

In an unprepared scason?

"Drop leaf-be silent song-

Cold things we came among!

We must warm them, we must warm them

Ere we even hope to charm them.

"Howbeit," here his face

Highten'd around the place, So to mark the outward turning Of his spirit's inward burning.

"Something it is to hold

In God's worlds manifold, First reveal'd to crcatures duty, A new form of His mild beauty.

"Whether that form rcspect

The sense or intellect, Holy rest in soul or pleasance, The clief Beauty's sign of prescnce.

" Holy in me and thee,

Rose fallen from the tree, Though the world stand dumb around ue, All unable to expound us 
"Though none us deign to bless,

Blessed are we natheless; Blessed age and consecrated In that, Rose, we were created !

"Oh, shame to poet's lays, Sung for the dole of praiseHoarsely sung upon the highway, With an "obolum da miti !"

"Shame! shame to poet's soul Pining for such a dole, When heaven-called to inherit The high throne of his own spirit !

"Sit still upon your thrones, O ye poetic ones! And if, sooth, the world decry you. Why, let that world pass by you!

"Ye.to yourselves suffice, Without its flatteries; Self-contentedly approve you Unto Him who sits above you.

"In prayers that upwara mount, Like to a sunned fount, And, in gushing back upon you, Bring the music they have won you! 
THE POETRY OF Y YOWRRD.

"In thanks for all the good

By poets understood-

For the sound of seraphs moving

Through the hidden depths of loving !

"For sights of things away,

'Through fissures of the clay, -

Promised things, which shall be given And sung ever up in heaven!

"For life, so lonely vain,

For death, which breaks the chain,For this sense of present sweetness, And this yearning to completeneas !" 


\section{EMBLEMS OF FLOWERS}

BY BURNS.

ADown winding Nith I did wander, To mark the sweet flowers as they spring . Adown winding Nith I did wander, Of Phillis to muse and to sing.

The daisy amused my fond fancy, So artless, so simple, so wild; 'Thou emblem, said I, o' my Phillis. For she is simplicity's child.

The rose-bud's the blush o' my cnarner, Her sweet balmy lip when 'tis prest: How fair and how pure is the lily, But fairer and purer her breast.

Yon knot of gay flowers in the arbout, They ne'er wi' my Phillis can vie: FIer breath is the breath of the woodbine, Its dew-drop o' diamond her eye.

Her voice is the song of the morning That wakes through the green-sfreading gro When Phobus peeps over the mountains, Olt music, and pleasure, and love. 
But beauty how frail and how fleeting, The bloom of a fine summer's day ? While worth in the Inind o' my Phillis Will flourish without a decay.

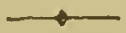 \\ THE ORANGE.BOUGH.}

BY MRS. HEMANS.

$\mathrm{O}$ ! ! bring me one sweet Orange-bough, To fan my cheek, to cool my brow ; One bough, with pearly blossoms drest, And bind it, Mother! on my breast !

Go scek the grove alcng the shore, Whose odours I must breathe no more, The grove where every scented tree Thrills to the deep voice of the sea.

Oh! Love's fond sighs, and ferrent prayes And wild farewell, are lingering there, Each leaf's light whisper hath a tone, My faint heart, even in death, would own.

Than bear me thence one bough, to shed Life's parting swectness round my head, And bind it, Mother! on my breasi When I am laid in lonely rest. 


\section{TO THE NARCISSUS}

BY BEN JONSON.

Arise, and speak thy sorrows, Echo, rise; Here, by this fountain, where thy love did pine, Whose memory lives fresh to vulgar fame, Shrined in this yellow flower, that bears his name,

\section{ECIIO.}

His namc revives, and lifts me up from earth ; See, see, the mourning fount, whose springs weep yet

Th' untimely fate of that too beauteous boy, That trophy of self-love, and spoil of nature, Who (now transform'd into this drooping flowcr) Hangs the repentant head back from the stream; As if it wish'd-would I liad never look'd In such a flattering mirror! $\mathrm{O}$, Narcissus! Thou that wast once (and yet art) my Narcissus, Had Echo but been private with thy thoughts, She would have dropt away herself in tears, Till she had all turn'd waste, that in her (As in a true glass) thou mightst have gazed, And seen thy beauties by more kind reflection, But self-love never yet could look on truth, But with blcar'd bcams; slick flattery and sho Are twill-born sisters, and do mix their eyos, As if you sever one, the other dies. 
Why did the gods give thee a heavenly form And earthly thoughts to make thee froud of it ? Why do I ask? 'Tis now the known disease 'That beauty hath, to bear too deep a sense Of her own self-conceived excellence. Oh hadst thou known the worth of Heaven's riah

$$
\text { gift, }
$$

Thou wouldst have turn'd it to a truer use, And not (with starved and eovetous ignorance) Pinsd in continual eyeing that bright gem, 'The glance whereof to others had been more 'Than to thy famish'd mind the wide world's store.

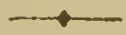 \\ THE HAREBELL.}

BY SCOTT.

"For me,"-she stoop'd, and looking round. Pluck'd a blue harebell from the ground,-"For me, whose memory scarce conveys An image of more splendid days, This little flower, that loves the lea, May well my simple emblem be; It drinks heaven's dew, blithe as the rose 'Ihat in the king's own garden grows; And when I place it in my hair, Allan, a bard is bound to swear He ne'er saw coronet sc fair." 


\section{SIVET LAVENDER.}

BY MISS STRICKLAND.

SWEET lavender! I love thy flower

Of meek and modest blue,

Which meets the morn and evening hour, The storm, the sunshine, and the shower, And changeth not its hue.

In eottage-maill's parterre thou'rt seen,

In simple touehing graee;

And in the garden of the queen,

'Midst eostly plants and blossoms sheen,

Thou also hast a place.

'The rose, with bright and peerless bloon.

Attraeted many eyes;

But while her glories and perfume

Expire before brief summer's doom,

'T'hy fragraneo never dies.

Thou art not like the fickle train

Our adverse fates estrange;

Who, in the day of grief and pain, Are fourd deceitful, light, and vain,

For thou dost never change. 
But thou art emblem of the friend,

Who, whatsoe'er our lot,

'The balm of faithful love will lend

And, true and constant to the end,

May die, but alters not.

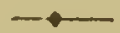 \\ THE HALF-BLOWN ROSE.}

\section{BY DANIEI.}

l.ook, now, now we esteem the half-blown rose The image of thy blush and summer's honour; Whilst yet her tender bud doth undisclose

That full of beauty time bestows upon her. No sooner spreads her glories to the air,

But straight her wide-blown pomp eomes to decline;

She then is scorn'd that late adorn'd the fair ;

So fade the roses of those eheeks of thine. No April can revive thy wither: $d$ flowers,

Whose springing graee adorns thy glory row ; Swift, speedy time, fearher'd with flying hours,

Dissolves the beauty of the fairest brow: Then do not thou such treasure waste in vain. But love now whilst thou nayst be loved again. 


\section{'T U TIIE DAISY.}

\section{BY WORDSWOORTH.}

Is youth fiom rock to roek I went

From hill to hill in discontent

Of pleasure high and turbulent,

Most pleased when most uneasy ;

But now my own delights I make; My thirst at every rill can slake, And nature's love of thee partake,

Her much-loved daisy!

Thee winter in the garland wears 'I'hat thinly decks his few gray hairs Spring parts the elouds with softest aire:

'That she may sun thee;

Whole summer-fields are thine by right ; And Autumn, melaneholy wight Doth: in thy erimson head delight When rains are on thee.

Be violets in their secret mews The flowers the wanton zephvis choose Proud be the rose, with rains and dewe Her head impearling; 
Thou livest with less ambitious aim, Yet hast not gone without thy flame; 'Thou art indeed, by many a claim, 'The poet's darling.

If to a rock from rains we fly, Or, some bright day of April sky, Imprison'd by hot sunshine lie Near the green holly, And wearily at length should fare; He needs but look about, and there Thou art! - a friend at hand, to scare His melancholy.

A hundred times, by rock or bower, Ere thus I have lain couch'd an hour, Have I derived from thy sweet powe: Some apprehension; Some steady love; some brief delight; Some memory that had taken flight; Some chime or fancy wrong or right ; Or strong invention.

If stately passions in me burn, And one chance look to thee should turn I drink out of an humble urn A lowlier pleasure ; 'T'he homely sympathy that heeds The common life, our nature breeds;

A wisdom fitted to the need 3

Of hearts at le isure. 
Fresh smitten by thy morning ray, When thou art up, alert and gay, Then, cheerfil flower! my spirits play With kindred gladness:

And when, at dusk, by dews opprest, 'Thou sink'st, the image of thy rest IIath often eased nuy pensive breast Of careful sadness.

- And all day long I number yet, All seasons through, another debt, Which $\mathrm{I}$, wherever thou art met,

'To thee am owing;

An instinet call it, a blind senseA happy, genial influence, Coming one knows not how, nor whence, Nor whither going.

Child of the year! that round dost run Thy pleasant course,-when day's begun, As ready to salute the sun

As lark or leveret, Thy long-lost praise* thou shalt regain ; Nor be less dear to future men 'Than in old time;-thou not in vain Art nature's favourite.

- Bee, In Chaucer and the elder poets, the honoura formerly paid to this flower. 


\section{LOVE'S WREATH.}

BY MOORE.

W HEN Love was a child, and went idling round Among flowers the whole summer's day, One morn in the valley a bower he found, So sweet, it allured him to stay.

O'erhead from the trees liung a garland fair,

A fountain ran darkly beneath ;

"T was Plcasurc that hung the bright flowers uf there,

Love knew it and jump'd at the wreath.

But Love did not know-and at his wcak years,

What urchin was likely to know ?-

That sorrow had made of her own salt tears,

'That fountain which murmur'd below.

He caught at the wreath, but with too much haste. As boys when impatient will do ;

It fell in those watcrs of briny taste, And the flowers werc all wet through.

Yet this is the wreath he wears night and daj; ; And though it all sunny appcars With Pleasure's own lustre, each leaf, they any, Still tasteg of the fountain $0^{\circ}$ tears. 


\section{TO A CROCUS.*}

\section{B $Y$ BE N A R D B RTOK.}

Weccome, wild harbinger of spring !

To this small nook of earth ;

Feeling and fancy fondly cling

Round thoughts which owe their birth

To thee, and to the liumble spot Where chance has fix'd thy lowly lot.

To thee,-for thy rich golden bloom,

Like heaven's fair bow on high,

Portends, amid surrounding gloom,

'That brighter hours draw nigh,

When blossoms of more varied dyes

Shall ope their tints to warmer skies.

Yet not the lily, nor the rose, Though fairer far they $b c$,

Can more delightful thoughts disclose

Than I derive from thee: The eye their beauty may prefer;

The heart is thy interpretcr :

Methinks in hy fair flower is seen,

By those whose fancies roam,

- a. wing up and llossoming beneath a wall towes 

An emblem of that leaf of green
The faithful dove brought home, When o'er the world of waters dark Were driven the inmates of the ark.

'I'hat lear betoken'd freedom nigh To mournful captives there ; Thy flower foretells a sunnier sky, And chides the dark despair By winter's chilling influence fluag O'er spirits sunk, and nerves unstrung.

And siveetly has kind nature's hand Assign'd thy dwelling-place Beneath a flower whose blooms expand, With fond congenial grace On many a desolated pile, Bright'ning decay with beauty's smile.

Thine is the flower of Hope, whose lue Is bright with coming joy ; ine wall-flower's that of faith, too true For ruin to destroy ; And where, O ! where should lupo upspring B'tl under faith's protecting wing. 


\section{ARRANGEMENTS OF A BOIQUET .}

\section{BY NICHOLAS DRAYTON.}

Here damask roses, white and red,

Out of my lap first take I, Which still shall run along the thread My chiefest flower this make I.

Amongst these roses in a row,

Next place I pinks in plenty,

These double pansies then for show, And will not this be danty?

The pretty pansy then I'll tie Like stones some cliain inchasing; And next to them, their near ally, The purple violet placing.

The curious choice clove July flower, Whose kind hight the carnation, For sweetness of most sovereign power. Shall help my wreath to fashion,

Whose sundry colours of one kind,

First from one root derived, Them in their several suits I'll bind:

My garland so contr.ved. 
A course of cowslips then I'll stick, And here and there (though sparely) 'The pleasant primrose down I'll prick, Like pearls that will show rarely;

'Then with these marigolds I'll make My garland somewliat swelling, 'These honeysuckles then I'll take, Whose sweets shall help their smelling.

The lily and the fleur-de-lis, For colour much contending, For that I them do only prize, They are but poor in scenting;

The daffodil most dainty is, To match with these in meetuess;

The columbine compared to this, All much alike for sweetness.

'These in their natures only are Fit to emboss the border, 'T'herefore I'll take especial care To place them in their order :

Eweet-williams, campions, sops-in-wine, One by another neatly: Thus have I made this wreat's of mine, And finished it featly 


\section{ON PLAN'TING A TULIP-ROOT,}

\section{BY MONTGOMERY.}

Itere lies a bulb the ehild of earth,

Buried alive beneath the clod, Ere long to spring, by seeond birth,

$A$ new and nobler work of God.

"Tis said that mieroseopie power

Might through his swaddling folds descry

The infant image of the flower,

Too exquisite to meet the eye.

'I'his vernal suns and rain will swell,

Till from its dark abode it peep,

Like Venus rising from her shell,

Amidst the spring-tide of the deep

Two shapely leaves will first unfold;

'Then, on a smooth, elastie stem, The verdant bud shall turn to gold, And open in a diadem.

Not one of Flora's brilliant raee A form more perfeet can display ! Art could not feign more simple grace, Nior Nat're take a line away. 
I et, sich as morn, of many a hus, When flushing clouds through darkness strik The 'Tulip's petals shine in dew

All beautiful, but none alike.

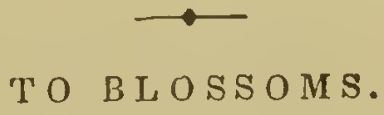

BY HERRICK.

FaIr pledges of a fruitful tree, Why do ye fall so fast? Your date is not so past

But youl may stay here yet awhilo,

To blush and gently smile,

And go at last.

What ! were ye born to be

An hour or hall's delight, And so to bid good-night?

'Twas pity nature brought ye forth Merely tc show your worth, And lose you quite.

But ye are lovely leaves, where wo May read how soon things have Their end, though ne'er so brave : And after they have shown their pride, Like you, awhile, they glide Into the grave. 


\section{A COMPARISON.}

BY .J. H. WIFFEN.

-As yon flower, with hyacinthine bells, Playful as light, which shiver'd by my tread,

Is turn'd to dust and darkness-to all else

It is as though it was not; swiftly sped

Spoil o'er its bruised buds which blossomed

A blending of all sweetness - what now ?

A few years hence, and over this bent head,

Dashing all life and gladness from the brow, 'The scythe of 'Time shall pass, and Ruin's silen plough.

\section{But the Spring,}

Fair as Aurora in ler purple cloud, Descends and wakens in their slumbering, Life from the ashes, beauty from the shroud. And speaks of immortality aloud To mourning man; and thus the flower I trod To its maternal dust shall issue proud Of its new birth, and on a greener sod Bow to the dil ying winds--a sign to man frow God, 


\section{THE EARLY PRIMROSE.}

Aske me why I send you here This firstling of the infant year; Aske me why I send to you This primrose all bepearl'd with dew; I straight will whisper in your ears, The sweets of love are washt with tear

Aske me why this flow'r doth show So yellow, green and sickly too; Aske me why the stalk is weak, And bending, yet it doth not break; I must tell you, these discover What doubts and fears are in a Lover.

\section{THE HOLLY.}

BY SOUTHEY.

0 READER ! hast thou ever stood to see The holly tree?

The eye that contemplates it well perceives

Its glossy leaves

Order'd by an Intelligence so wise:

As might confound the Atheist's sophistries. 
Beluw a circling fence, its lcaves are seen Wrinkled and keen;

No grazing cattle through their prickly round

Can reach to wound,

But as they grow where nothing is to fear, Sniooth and unarm'd the pointless leaves appear

NARCISSUS.

BY GRAY.

Here young Narcissus o'er the fountain stood, And viewed his image in the crystal flood; The crystal flood reflects his lovely charms, And the pleased image strives to meet his arms. No nymph his inexperienced breast subdued; Echo in vain the flying boy pursued. Himself alone the foolish youth admires, And with fond look the smiling shade desires, O'er the smooth lake with fruitless isars ho grieves :

His spreading fingers shoot in verdant leaves: Through his pale veins green sap now gently flows And in a short-lived flower his beauty blows. Let vain Narcissus warn each female brcast 'I'hat beauty's but a transient good at best; Like flowers, it withers with th' advancing year, And age, liks winter, robs the blooming fair. 
TUE POETKY OF FLOW EUS.

\section{ANACREON 'TO 'THE ROSL.}

' $W$ nII. we involsc the wreathed spring, Resplendent Rose! to thce we'll sing, Resplendent Rose! the flower of flowern. Whose breath perfumcs Olympus' bownm, Whose virgin blush, of chasten'd dye, Enchants so mueh our mortal eye, Oft has the poet's magic tongue The Rose's fair luxuriance sung ; And long the Muses, heavenly maids Have rear'd it in their tuneful shades. When, at the early glance of morn, It sleeps upon the glittering thorn, 'Tis sweet to dare the tangled fence, To cull the timid floweret thence, And wipe, with tender hand, away The tear that on its blushes lay ! 'Tis swcct to hold the infant stems, $Y$ et dropping with Aurora's gcms, And fresh inhale the spicy sighs That from the weeping buds arise. When revcl reigns, when mirth is high And Bacchus beams in every eye, Our rosy fillers scent exhale, Ind fill with balm the fainting gale! $\mathrm{Oh}$, there is nonglı: in nature bright, Vhere $R$ zars fon not ehed their light ' 
Where morning paints the orient skies,

Iler fingers burn with roseate dyes! And when, at length, with pale decline,

Its florid beauties fade and pine, Swcct as in youth its balmy breath Diffuses odour e'en in death !

$O$, whence could such a plant have sprung $\mathbf{l}$

Attend-for thus the tale is sung:-

When humid from the silvery stream,

Effusing beauty's warmest beam,

Venus appeared in flushing hues, Mellowed by Ocean's briny dcws;

When, in the starry courts above, 'The prcgnant brain of mighty Jove Disclosed the nymph of azure glance? The nymph who shakes the martial lance! Then, then, in strange eventful hour, The earth produced an infant flower, Which sprung with blishing tinctures dress' $\boldsymbol{d}_{\text {: }}$ And wanton'd o'er its parent breast. T'he gods beheld this brilliant birth, And hail'd the Rose, the boon of earth . With nectar drops, a ruby tide. 'The sweatly orient buds they dycd, And bade them bloom, the flowers divine of him who sheds the teening vine; And bade them on the spangled thorn Exond their bosoms to the morn. 


\section{DECISION OF THE FLOWER.}

\section{BY L. E. LANDON.}

A A will scarlet poppies, around like a bower. 'The maiden found her mystic flower. "Now, gentle flower, I pray thee tell If $m y$ lover loves me, and loves me well: So may the fall of the morning dew Keep the sun from fading thy tender blue, Now I number the lcaves for my lotHe loves not-he loves me-he loves me notHe loves mc-yes, thou last leaf, yesI'll pluck thee not for the last sweet guess! He loves me !"- "Yes," a dear voicc sigh'd And her lover stands by Margaret's side.

\section{THE SNOW-D R OP.}

BY MARY ROBINSON.

'Tre snowdrop, Winter's timid child, Awakes to life, bedew'd with tears, And flings around its fragrance mild; And, where no rival flowerets bloom; Amidst the bare and chilling gloon?,

A beauteous gem appears. 
All weak and wan with head inclined,

I.ts parent breast the drifted snow,

It trembles, while the ruthless wind

Bends its slim form; the tempest lowers,

Its emcrald eye drops crystal showers

On its cold bed below.

Where'er I find thee, gentle flower, Thou still art sweet and dear to me ' For I have known the cheerless hour, Have seen the sunbeams cold and pale, Have felt the chilling wintry gale, And wept and shrunk, like thee!

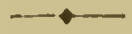 \\ DAFFODILS.}

$F_{\text {AIR }}$ Daffodils, we weep to see

You haste away so soon;

As yet the early rising sun

Has not attained his noon:

Stay, stay

Until the hastening day

Hlas run

But to the even-song,

And, laving pray'd together, we

will go with vou along. 
We have short time to stay as ye,

We have as fleet a spring,

As quick a growth to meet decay

As you or any thing;

We die

As your hours do, and dry

Away,

Like to the summer's rain,

Or as the pearls of morning's dew,

$\mathrm{Ne}$ 'er to be found again.

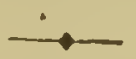

\section{THE SHEPHERD TO THE FLOWERS.}

\section{BY SIR WALTER RALEIGH.}

SWEET violets, love's paradise, that spread Your gracious odours, which you, couched, bear Within your paly faces,

Upon the gentle wing of some calm.breathing wind,

That plays amidst the plain!

If, by the favour of propitious stars, you gain, Such grace as in my lady's bosom place to finci,

Be proud to touch those places: And when her warmth your moisture forth doih wear,

Whereby her dainty parts are sweetly fed, 
Yod, honours of the flowry meads, I pray, You pretty daughters of the earth and sun, IVith mild and seemly breathing straight display My bitter sighs, that have my heart undone'

\section{HEART'S.EA SE.}

BY SHAKSPEARE.

\section{I sAw,}

Flying between the cold moon and the earth, Cupid all arm'd; a certain aim he took At a fair vestal throned in the west.

And loosed his love-shaft smartly from his bow, As it should pierce a hundred thousand hearts. But I might see young Cupid's fiery shaft Quench'd in the chaste beams of the wat'ry moon. And the imperial vot'ress passed on, in maiden meditation, fancy-free. Yet marked I where the bolt of Cupid fell: It fell upon a little western flower, Before milk-white, now purple with love's woura, And maidens call it Love in Idleness. The juice of it, on sleeping pyelids laid, Will make a man or woman madiy dote Upon the next live creature that $i^{+}$. sees. 


\section{THE SCARLET GERANIUM.}

I wILL not sing the mossy rose, The jasmine sweet, or lily fair, The tints the rich carnation shows, The stock's sweet scent that fills the air.

Full many a bard has sung their praise In metres smooth, and polished line; A simple flower and humbler lays May best befit a pen like mine.

There is a small but lovely flower, With crimson star and calyx brown, On pathway side, beneath the bower, By Nature's hand profusely strown.

Inquire you when this floweret springs ?-

When Nature wakes to mirth and love, When all her fragrance summer flings, When latest autum chills the grove.

Like the sweet bird whose name it bears, 'Midst falling leaves and fading flowers. The passing traveller it cheers, In shorten d days and darksome hour. 
And, should you ask me where it blowe

I answer, on the mountains bare,

High on the tufted rock it grows,

In loncly glcus or meadows fair.

It blooms amidst those flowery dales Where winding Aire pursues its courso:

It amiles upon the criggy fells

That rise around its lofty source.

'I'herc arc its rosy petals shown, 'Midst curious forms and mosses rare, Imbedded in the dark gray stonc,

When not another flower is therc.

Oh! emblem of that steadfast mind Which, through the varying scenes of lis $\theta_{1}$ By genuinc piety refined, Holds on its way 'midst noise and strife.

Thongh dark the impending tempest lower, The path of beauty it espics, calm 'midst the whirlwind and the shower, Thankful when brightcr hours arise.

Oh! could our darken'd minds discern In thy swcet form this lesson plain, Could we it practically Icarn, Herb Robert would no: blnom in vain. 


\section{IHE HELIO'T R O P L.}

THERE is a flower, whe se modest eye Is turn'd with looks of light and love, Who breathes her softest, sweetest sigh,

Whene'er the sun is bright above.

Let clouds obscure, or darkness veil,

Her fond idolatry is fled;

Her sighs no more their sweets exhale,

The loving eye is cold and dead.

Canst thou not trace a moral here,

False flatterer of the prosperous hour ?

Let but an adverse cloud appear, And thou art faithless as the flower.

\section{ARMOUR OF THE ROSE.}

Youne Love, rambling through the wood,

Found me in my solitude,

Bright with dew and freshly blowis,

And trembling to the Zephyr's sighs;

But as he stoop'd to gaze upon

The living gem with raptured eyes,

It chanced a bee was busy there,

Searching for its fragrant fare . 
And, Cupid, stooping too, to sip, 'The angry inscet stung his lip: And, gushing from the ambrosial cell, One bright drop on my bosom fell. IVecping, to his mother he 'Told the talc of treachery, And she her vengeful boy to please, Strung his bow with eaptive bees, But placed upon my slender stem 'The poisoned sting she plucked from them s And none sincc that eventful morn Have found the flower without a thorn.

\section{$\cdots$ \\ THF FORGET.ME-NOT.}

Nor on the mountain's shelving side,

Nor in the cultivated ground,

Nor in the garden's painted pride,

'The flower I seek is found.

Where 'Time on sorrow's page of gloom

Has fix'd its enr:ous lot,

Or swep: the record from the tomb,

It says, Forget-me-not.

And this is still the loveliest flower, The fairest of the fair, of all that deek my lady's bower,

() $r$ bino her incolling hois 


\section{FIELD LEAVES.}

\section{BY ELIZABFTH OAK SMITH.}

TнE tender violets bent in smiles 'To the clves that sported nigh, Tossing the drops of fragrant dew To scent the evening sky.

They kiss'd the rose in love and mirth, And its petals fairer grew ;

A snower of pearly dust they brought And over the lily threw.

I saw one dainty creature crown The tulip's painted cup, And bless with one soft kiss the urn. Then fold its petals up.

A finger rock'd the young pird's nest, As high on a branch is hung, While the gleaming night dew rattled down Where the old dry leaf was Pung. 


\section{ON THE INDIAN-JASMINF: FLOWER.}

\section{BY RYAN.}

How lovelily the jasmine flower Blooms far from man's observing eyes ; And iıaving liveả its litile hour, 'There withers, - there sequester'd dies!

Though faded, yet 'tis not forgot; A rich perfume, time eannot sever, Lingers in that unfriended spot, And decks the jasmine's grave for ever.

Thus, thus should man, who seeks to soar On learning's wings to fame's bright $s k y_{\text {, }}$ Far from his fellows scek that lore,

Unheeded live, sequester'd die.

Thus, like the jasmine, when he's fled, Fame's rich perfume will ever keep, Ling'ring around the faded dead, As saints that watch some infant's sleep. 


\section{THE EVENING PRIMROSE.}

BY BERNARD BARTON.

FaIr flower, that shunn'st the glare of daz.

Yet lovest to open, meekly bold.

To evening hues of sober gray,

Thy cup of paly gold;

Be thine the offering, owing long,

To thee, and to this pensive hour,

of the brief tributary song,

Though transient as thy flower.

I love to wateh at silent eve 'Thy scatter'd blossoms' lonely light :

And have my inmost heart receivo

The influence of that sight.

I love, at sueh an hour, to mark, 'Their beauty greet the light breeze chill, And shine, 'mid shadows gathering dark, The garden's glory still.

For such, 'tis sweet to think the while, When eares and griefs the breast invado In friendship's animating sinile,

In sorrow's dark'ning shade. 
Thus it bursts forth like thy pale cup, Glist'ning anid its dewy tears, And bears the sinking spirit up Amid its chilling fears ;

But still more animating far,

If meek religion's eye may trace, Even in thy glimm'ring earth-born star 'The holier hope of grace!

The hope that, as thy beauteous bloom Expands to glad the close of day, Ro through the shadows of the tomb May break forth mercy's ray. 


\section{TO AN EARLY PRIMROSE}

BY H. K. WHITE.

MILD offspring of a dark and sullen sire !

Whose modest form, so delicately fine,

Was nursed in whirling storms,

And cradled in the wind.

Thee, when young Spring first question:'d Winter's sway,

And dared the sturdy blusterer to the fight-

Thee on this bank he threw,

'To mark his victory.

In tnis tow vale, the promise of the year,

Serene thou openest to the nipping gale,

Unnoticed and alone,

'Thy tender elegance.

So virtue blooms, brought forth amid the storms Of chill adversity, in some lone walk

Of life she rears her head,

Obscure and unobserved;

While every bleaching breeze that on lier hlows, Chastens her spotless purity of breast,

And hardens her to bear

Serene the ills of life. 


\section{THE ROSE BUD.}

\section{BY KEBLE.}

WHEN nature tries her finest touch, Weaving her vernal wreath, Mark ye how close she veils her round, Not to be traeed by sight or sound. Nor soil'd by ruder breath ?

Whoever saw the earliest rose First open her sweet breast? Or, when the summer sun goes down, The first, soft star in evening's crown Light up her gleaming erest?

Fondly we seck the dawning bloom On features wan and fair,The gazing eye no ehange can trace, But look away a little space, 'Then turn, and lo! 'tis there.

But there's a sweeter flower than e'er Blush'd on the rosy sprayA brighter star, a richer bloom, 'I'han e'er did western heaven illume At elose of summer day. 
'Tis love, the last best gift of heaven; Luve gentle, holy, pure :

But tenderer than a dove's soft eye,

'Ihe searcling sun, the open sky, She never could endure.

Even human love will shrink from sight

Here in the coarse rude earth:

How then should rash intruding glanie

Break in upon her sacred trance

Who boasts a heavenly birth?

So still and secret is her growth,

Ever the iruest heart, Where deepest strikes her kindly reot For hope or joy, for flower or fruit,

Least known its happy part.

God only, and good angels, louk

Behind the blissful screen-

As when, triumphant o'er his woes,

The Son of God, by moonlight rose,

By ail but heaven unseen:

As when the Hcly Maid beheld

Her risen Son and Lord:

Thought has not colours half so tair

That she to paint that hour may dare,

In silence best adored. 
The gracious dove, that brought from heavea The earnest of our bliss,

Of many a chosen witness telling,

On many a happy vision dwelling, Sings not a note of this.

So, truest image of the Christ,

Old Israel's long-lost Son, What time, with sweet forgiving cheer, He call'd his conscious brethren near, Would weep with them alone.

He could not trust his melting soul

But in his Maker's sight-

'Then why should gentle hearts and true Bare to the rude world's withering view Their treasures of delight?

No-let the dainty rose awhile

Her bashful fragrance hideRend not her silken veil too soon, But leave her, in her own soft noon, Tc flourish and abide. 


\section{THE GARLAND.}

\section{BY PRIOR.}

Tre pride of every grove I ehose,

The violet sweet, the lily fair, The dappled pink and blushing rose, 'To deek my eharming Chloe's hair.

At morn the nymph vouehsafed to placs

Upon her brow the various wreath; The flowers less blooming than her faee, The seent less fragrant than her breath

The flowers she wore along the day: And every nymph and shepherd said, That in her hair they look'd more gay Than glowing in their native bed.

Undress' $d$ at evening, when she found Their odours lost, their eolours past ; She ehanged her look, and on the ground Her garland and her eye she east.

That eye dropp'd sense distinct and clear, " As any Muse's longue eould speak, When from its lid a pearly tear

Ran triekling do'vn her beauteous cheek 
Dissernbing what I knew too well, My love, my life, said I, explain

This change of humour: pr'ythee tell: That falling tear-what does it mean?

She sigh'd: she smiled: and to the flower Pointing, the lovely moralist saidSee, friend, in some few fleeting hours. See yonder, what a change is made.

Ah me ! the blooming pride of May, And that of beauty, are but one: At morn both flourish bright and gay ; Both fade at evening, pale, and gone.

At dawn poor Stella danced and sung, The amorous youth around her bow'd, At night her fatal knell was rung ; I saw, and kiss'd her in her shroud.

Such as she is, who died to-day, Such I, alas! may be to-morrow ; Go, Damon, bid the Muse display The justice of thy Chloe's sorrow. 


\section{THE FIELD-FLOWER.}

\section{BY MONTGOMERY.}

There is a flower, a little flower,

With silver crest and golden eye, That welcomes every changing hour, And weathers every sky.

The prouder beauties of the ficld In gay but quick succession shine, Race after race their honours yield, They flourish and decline.

But this small flower, to nature dear, While moon and stars their courses rus. Wreathes the whole circle of the year, Companion of the sun.

It smiles upon the lap of May, To sultry August spreads its charms, Lights pale October on his way, And twines December's arms.

The purple heath, and golden broom, On moory mountains catch the galo O'er lawns the lily sheds perfume, The violet in the vale; 
But this bold floweret climbs the hil ${ }_{4}$ Hides in the forest, haunts the glea Stays on the margin of the rill, Peeps round the fox's den.

Within the garden's cultured round

It shares the sweet carnation's bed; And blooms in consecrated ground In honour of the dead.

The lambkin crops its crimson gem, The wild-bee murmurs on its breast T.'he blue-fly bends its pensile stem, Light o'er the skylark's nest.

'Tis Flora's page :-in every place, In every season, fresh and fair, It opens with perennial grace, And blossoms every where.

On waste and woodland, rock and plaiı fts humble buds unheeded rise; The rose has but a summer reign, The daisy never dies. 


\section{TO THE SNOW-DROP.}

\section{BY KEBLE.}

Troo first-born of the years' delight,

Pride of the dewy glade,

In vernal green and virgin white,

Thy vestal robes, array'd :

'Tis not because thy drooping form

Sinks grateful on its nest,

When chilly shades from gathering storia

Affright thy tender breast;

Nor from yon river islet wild

Beneath the willow spray,

Where, like the ringlets of a child,

Thou wear'st thy circle gay;

'Tis not for these I love thee dear,-

Thy shy averted smiles

To fancy bode a joyous year,

One of life's fairy isles.

They twinkle to the wintry moon, And cheer the ungenial day, And tell us all will glisten soon As green and bright as they. 
Is there a heart that loves the spring. Their witness can refuse?

Yet mortals doubt, when angels bring From heaven their Easter news :

When holy maids and matrons speak Of Christ's forsaken bed,

And voices, that forbid to seek The living 'mid the dead;

And when they say, "T'urn, wandering heas" "Thy Lord is risen indeed, Let pleasure go, put care apart, And to his presence sf zed;"

We smile in scorn: and yet we know They early sought the tomb, Their hearts that now so freshly glow, Lost in desponding gloom.

They who have sought, nor hope to find, Wear not so bright a glance : They who have won their earthly mind, Less reverently advance.

But where, in gentle spirits, fear And joy so duly meet, These sure have seen the angels near. And kiss'd the Savour's feet. 
No. let the pastor's tharkful eye $\mathrm{T}$. seir faltering tale disdain, As un their lowly couch they lie. Prisoners of want and pain.

$\mathrm{O}$ guide us, when our faithless hearts From thee would start aloof, Where patience her sweet skill imparts Benearh some cottage ronf:

Revive our dying fires to burll High as her anthems soar, And of our scholars let us learn Our own forgotten lore.

\section{COWSLIPS.}

BY MA R Y HOWITT.

$N_{A}$, tell me not of Austral flowers, Or purple bells from Persia's bowerg, 'The cowslip of this land of ours, Is dearer far to me ! 'This flower in other yeare I knew! I know the field wherein it grew, With violets white and violets blue, Beneath the garden tree. 
I never see these flowers but they Send back my memory, far away, To years long past, and many a day Else perish'd long ago!

They bring my childhood's years againOur garden-fence, I see it plain, With ficaries like a golden rain Shower'd on the earth below.

A happy child, I leap, I run, And memories come back, one by one, Like swallows with the summer sun, To their old haunts of joy ! A happy child, once more I stand, With my kind sister, hand in hand, And hear those tones, so sweet, so bland, That never brought annoy!

I hear again my mother's wheel, Her hand upon my head I feel ; Her kiss, which every grief could hea.,

Is on my cheek even now ;

I see the dial overhead;

I see the poreh o'er which was led, 'The pyracantha green and red, And jessamine's slender bough.

I see the garden-thicket's shade, Where all the summer long we play'd, And gardens set, and houses made, Our early work and late; 
Our little gardens, side by side, Each border'd round with London pride Some six feet long, and three feet wide. To us a large estate !

The apple and the damson trees, The cottage shelter for our bees; I see them-and beyond all these, A something dearer still;

I see an eye serenely blue, A cheek of girlhood's freshest hue, A buoyant heart, a spirit true, Alike in good and ill.

Sweet sister, thou wert all to me, And I sufficient friend for thee : Where was a happier twain than we Who had no mate beside?

Like wayside flowers in merry May, Our pleasures round about us lay ; A joyful morning had our day, Whate' 3 sal evo betide! 


\section{H E A R T'S-E A S E.}

\section{BY MRS. SHERIDAN.}

Is gardens oft a beauteous flower there grows, By vulgar eyes unnoticed and unseen; In sweet serenity it humbly blow's, And rears its purple head to deck the green.

This flower, as nature's poct sweetly sings, Was once milk-white, and heart's ease was it name,

'Till wanton Cupid poised its roseate wings, A vestal's sacred bosom to inflame.

With treacherous aim the god his arrow drew, Which she with icy coldness did repel

Rebounding thence with feathery speed it flew, 'Till on this lonely flower, at last, it fell.

Heart's-ease no nire the wandering shepherc found;

No more the nymphs its snowy form possess; Its white now changed to purple by love is wound, Hoart's-ease no more,- - tis love-in-idleness. 
T Ǩ POETRY OF FLOWIRS.

T ( THE SWEET-BRIER。

BY J. G. C. BRAINARD.

QUR sweet autumnal western-scented wind Robs of its odours none so sweet a flower, In all the blooming waste it left behind, As that sweet-brier yields it ; and the shower Wets not a rose that buds in beauty's bower

One half so lovely; yet it grows along 'The poor girl's pathway; by the poor man's door.

Such are the simple folks it divells among; And humble as the bud, so humble be the song.

I love it, for it takes its untouch'd stand Not in the vase that sculptors decorate; Its sweetness all is of my native land; And e'on its fragrant leaf has not its mate Among the perfumes which the rich and great Bring from the odours of the spicy East. You love your flowers and plants, and will you hate

The little four-leaved rose that I love best, That freshest will awake, and sweetest go to rests 


\section{MOTHER'S DIRGE OVER HER CHILI)}

BY D. M. MIOIR.

Bring me flowers all young and sweet, That I may strew the winding-sheet, Where calm thou sleepest, baby fair, With roseless cheek and auburn hair.

Bring me the rosemary, whose breath Perfumed the wild and desert heath; The lily of the vale, which too, In silence and in beauty grew.

Bring cypress from some sunless spot, Bring me the blue forget-me.not; That I may strew them o'er thy bier, With long-drawn sigh and gushing tear.

Oh, what upon this earth doth prove So steadfast as a mother's love! $\mathrm{Ol}$, what on earth can bring relief Or solace to a mother's grief!

No more my baby shalt thou lie, With drowsy smiles and half-shut eye, Pillow'd upon my fostering breast, Serenely sinking into rest! 
Thy grave must be thy cradle now ; The wild flowers o'er thy breast shall glow', While still my heart, all full of thee, In widow'd solitude shall be.

No taint of earth, no thought of sin, E'er dwelt thy stainless breast within, And God hath laid thee down to sleep, Like a pure pearl below the deep.

Yea! from mine arms thy soul hath flown Above, and found the heavenly throne, To join that blest angelic ring, That aye around the altar sing.

I. thought, when years had roll'd away, 'That thou wouldst be my age's stay; And often have I dream'd to see 'The boy-the youth-the man in thee !

But thou hast past ! for ever gone, 'To leave me childless and alone, Like Rachel frowning tear on tear. And looking not for comfort here !

Farewell, my child, the dews shall fall, At noon and evening, o'er thy pall ; And daisies, when the vernal year Revives, upon thy turf apnear. 
The earliest snow-drop there shall spring, And lark delight to fold his wing; And roses pale, and lilies fair, With perfume load the summer air !

Adieu, my babe! if life were long. 'I'his would be even a heavier song ; But years, like phantoms, quickly pass, They look to us from memory's glass.

Soon on death s couch shall I recline; Soon shall my head be laid with thine; And sunder'd spirits nıeet above, To live for evermore in love.

\section{$\longrightarrow$ \\ TH E R O SE.}

TRANSLATED FHOM CAMOENS

Just like love is yonder rose :Heavenly fragrance round it throws, Yet tears its dewy leaves disclose, And in the midst of briers it blows;

\section{Just like Love.}

Cull'd to bloom upon the breast, Since rough thorns the stem invest, They must be gatlier'd with the rest, And with it to the leart be prest; 
And when the rude hands the twin buds sever They die, and they shall blossom never; Yet the thorns be sharp as over;

\section{Just like Love.}

\section{"GO TO THE FOREST SHADE."}

BY MRS. HEMANS.

Go is the forest shade-

Seek thou the well known glade. Where, heavy with sweet dew, the violets lie,

Gleaming through moss-tufts deep,

Like dark eyes fill' $d$ with sleep, And bathed in hues of summer's midnight sky

Bring me their buds, to shed Around my dying bed A breath of May, and of the Wood's repose;

For I in sooth depart

With a reluctant heart, T'hat fain would linger where the bright sun glows.

Fain would I stay with thee-

Alas! this may not be;

Yet bring me still the gifts of happier hours!

Go where the fountain's breast

Catches, in glassy rest,

Tue dim green light that pours through laurol lowers. 
I know how sofily bright, Steep'd in that tender light,

The water-lilies tremble there e'en now;

Go to the pure stream's edge,

And from its whispering sedge

Bring me those flowers to cool my fever'd brow

'Then, as in hope's young days.

'T'rack thou the antique maze

of the rich garden to its grassy mound;

'There is a lone white rose,

Shedding, in sudden snows,

Its faint leaves o'er the emerald turf around.

Well knowest thou that fair tree-

A murmur of the bee

Dwells ever in the honey'd lime above;

Bring me one pearly flower

Of all its clustering shower-

For on that spot we first reveal'd our love.

Gather one woodbine bough, Then, from the lattice low

Of the bowered cottage which I bade thee mark

When by the hamlet last,

'Through dim wood-lanes we pass'd,

While dews were glancing to the glow-w rrm' spark. 
Haste ! to my pillow bear

Those fragrant things and fair,

Thy hand no more may bind them ur at eve-

Yet shall their odour soft

One bright dream round me waft

Of life, youth, summer-all that I must leave'

And, oh ! if thou wouldst ask

Wherefore thy steps I task,

The grove, the stream, the hamlet vale to traco,

'Tis that some thought of me,

When I am gone, may be

The spirit bound to each familiar place.

I bid mine image dwell

(Oh! break not thou the spell!)

In the deep wood and by the fountain side;

Thou must not, my beloved!

Rove where we two have roved,

Forgetting her that in her spring-time died' 


\section{TO A JASMINE-TREE}

GROVING IN TIE COURT OF HATORTH CASTIE.

\section{BY LORD MORPETH.}

My slight and slender jasmine-tree,

That bloomest on my Border tower,

Thou art more dearly loved by me,

Than all the wealth of fairy bower.

I ask not, while I near thee divell,

Arabia's spice or Syria's rose ;

Thy bright festoons more freshly smell,

Thy virgin white more freshly glows.

My mild and winsome jasmine-tree,

That climbest up the dark gray-wal'. Thy tiny flowerets seem in glee,

Like silver spray-drops down to fall:

Say, did they from their leaves thus peep,

When mail' $d$ moss-troopers rode the hill

When helmed wardens paced the keep,

And bugles blew for Belted Will?

My free and feathery jasmine-tree,

Within the fragrance of thy breath,

Yon dungeon grated to its key,

And the chain'd captive pined for c'eath.

On Border fray, on feudal crime,

I dream not while I gaze on thee;

The chieftains of that stern old time

Cuald ne'er have loved a jasmine-tree. 


\section{APRIL FLOWERS.}

\section{RY BISHOP MANT.}

Nor, April, fail with scent and hue, To glace the lowlier blossoms new. Not only that, where weak and scant Peep'd forth the early primrose plant, Now shine profuse unnumber'd eyes, Like stars that stud the wintry skies; But that its sister cowslip's nigh, With no unfriendly rivalry Of form and tint, and fragrant smells, $\checkmark$ 'er the green fields their yellow bello Unfold, bedropt with tawny red, And meekly bend the drooping head Fot only that the fringed edge Of heath, or bank, or pathway hedge, Glows with the furze's golden bloom; But mingling now, the verdant broom With flowers of rival lustre deck'd, Uplifts its shapelier form erect. And there upon the sod below, Ground-ivy's purple blossoms show, like helmet of crusader knight, Its anthers' crosslike forms of whito And lesser periwinkle's bloom, Like carpet of Damascus' loom. 
Pranks with bright blue the tissue wove of verdant foliage; and above, IV ith milk-white flowers, whence soon slsall s woln Rich fruitage, to the taste and smell Pleasant alike, the strawberry weaves Its eoronets of three-fold leaves, in mazes through the sloping wood. Nor wants there in her dreamy mood, What fancy's sportiveness may think A eup, whenee midnight elves might drink Delicious drops of nectar'd dew, While they their fairy sports pursue, And roundelays by fount or rill'The streak'd and chequer'd daffodil.

Nor wants there many a flower beside. On holt, and hill, and meadow pied; With pale green gloom the upright box: And woodland crowfoot's golden locks; And yellow cinquefoil's hairy trail ; And saxifrage with petal pale; And purrie bilberry's globelike head; And eranberry's bells of rosy red; And creeping groundsel blue and bright; And eranesbill's streaks of red and white, On purple with soft leaves of down, And golden tulip's turban'd crown, Sweet scented on its bending stem; And bright-eyed star of Bethlenem; With those, the firstlings of their kind, Whieh through the bosky thiekets wind 
Their tendrils, vetch, or pea, or tare, At random; and with many a pair Of leaflets green the brake embower, And many a fendant-painted flower.

\section{FLOWERS.}

BY ELIZABETH OAK SMITH,

Each leaftet is a tiny scroll

Inscribed with holy truth,

A lesson that around the heart

Should keep the dew of youth; Bright missals from angelic throngs

In every by-way left

How were the earth of glory shorn

Were it of flowers bereft !

They tremble on the Alpine heights,

The fissured rock they press,

'The desert wild with heat and sanc,

Shares too their blessedness;

And wheresoe'er the weary heart

Turns in its dim despair,

The meek-eyed blossom upward looks,

Inviting it to rrajer? 


\section{TIIE OR CHIS.}

BY SNOW.

SEe, Delia, see this image bright, Why starts my fair one at the sight? It mounts not ca offensive wing, Nor threats thy breast with angry sting; Admire, as close the insect lies, Its thin-wrought plume and honey'd thighs: Whilst on this flowcret's velvet breast, It seems as though 'twere lull'd to rest. Nor might its fairy wings unfold. Enchain'd in aromatic gold. Think not to set the captive free, " $\Gamma$ is but the picture of a bee.

Yet wonder not that nature's power, Should paint an insect in a flower, And stoop to means that bear in pare Resemblance to imperfect art. Nature, who could that form inspire With strength and swiftness, life and fire, And bid it search each spicv vale, Where flowers thcir fragrant souls exhale; And labouring for the parent hive, With murmurs make the wild alive. For when in Parian stone we trace Some best remember'd form or faco: 
Or see on radiant canvass rise An imitative paradise; And feel the warm affections glow, Pleased at the pencil's mimic show; "I'is but obedience to the plan From nature's birch opposed to man, IVho, lest her choicest sweets in vain Should blossom fer our thankless train; I rest beauty pass unheeded by, Like cloud upon the summer sky; Lest memory of the brave and just, Should sleep with them confined to dust: ; With leading liand the expedient proves, And paints for us tie form she lovee. 


\section{'THE DAISY IN IND I A}

BY JAMES MONTGOMERY.

Thrice welcome, little English flower ! Thy mother country's white and red, In rose or lily, till this hour

Never to me such beauty spread: Transplanted from thy island bed,

A treasure in a grain of earth, Strange as a spirit from the dead Thy embryo sprang to birtl.

Thrice welcomc. little English flower . Whose tribes beneath our native skies Shut close their leaves while vapours lower,

But when the sun's gay beams arise, With unabash'd but modest eyes,

Follow his motion to the west, Nor cease to gaze till daylight dies, 'I'hen fold themselves to rest.

Thrice welcome, little English flower.

To this resplendent hemisphere, Where Flora's giant-offspring tower

In gorgeous liveries all the year; Thou, only thou, art little here,

Like worth unfriend:d and unknown, 
Yet to my British heart more dear Than all the torrid zone.

Thriee weleome, little English flower ! Of early seenes beloved by me, While happy in my father's bower, Thou shalt the blithe memorial be; The fairy sports of infaney, Youth's golden age, and manhood's prime, Home, country, kindred, friends, - with thee Are mine in this far elime.

Thriee welcome, little English flower I'll rear thee with a trembling hand;

$O$ for the April sun and shower, The sweet May-dews of that fair land, Where daisies, thick as star.light, stand In every walk ! - that here might shoot Thy seions, and thy buds expand, A hundred from one root!

Thrice weleome, little English flower: To me the pledge of hope unseen : When sorrow would my soul o'erpower For joys that were, or might liave been, I'll call to mind, how-fresh and greenI saw thee waking from the dust; Then turn to heaven, with brow serene, And place in God my trust. 


\section{'IHE PRIMROSE OF THE ROCIK.}

\section{BY WORDSIFORTH.}

A ROCK there is whose lonely front The passing traveller slights ; Yet there the glow-worms hang t!leir lamps,

Like stars, at various heights; And one coy primrose to that rock The vernal breeze invites.

What hideous warfare hath been waged What kingdoms overthrown, Since first I spied that primrose tuft, And mark'd it for my own!

A lasting link in nature's chain From highest heaven let down.

'The flowers, still faithful to the stems, Their fellowship renew; The stems are faithful to the root, That worketh out of view ; And to the rock the root adheres, In every fibre true.

Close clings to earth the living rock, Though threatening still to fall; The earth is constant to her sphere, And God uploolds thern all: 
So blooms this lonely plant, nor drcads

Her annual funeral.

Here closed the meditative strain;

But air breathed soft that day,

'The hoary mountain heights were cheer'd,

'I'he sunny vale look'd gay;

And to the primrose of the rock

I gave this after lay.

I sang-Let myriads of bright flowers,

Like thee, in field and grove,

Revive unenvied ;-mightier far,

Than trcmblings that reprove

Our vernal tendencies to hope,

Is God's redeeming love;

That love which changed-for wan diseaw

For sorrow that had bent,

O'er hopeless dust, for wither'd age -

Their moral element,

And turn'd the thistles of a curse

'To types beneficent.

Sin-blighted though we are, we ton,

The reasoning sons of men,

From our oblivious winter call'd,

Shall rise and breathe again;

And in eternal summer lose

Our threescore years and ten. 
To humbleness of heart descends This prescience from on high, The faith that elevates the just, Before and when they die ; And makes each soul a separate heaven, A court for Deity.

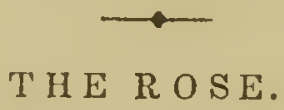

RY SPENSER.

Ar! see the virgin rose, how sweelly she Doth first peep forth with bashful modesty, That fairer seems the less ye see her way!

Lo! see soon after, how more bold and free Her bared bosom she doth broad display ; Lo! see soon after, how she fades away ard falls

\section{$-\cdots$ \\ INFANT SLUMBER.}

A HoLx smile was on her lip, Whenever sleep was there, She slept, as sleeps the blossom, 'insh'd Amid the silent air.-E. OAK SNitr. 


\section{THE VIOLET.}

BY MISS L. E. I.ANDON.

WuY better than the lady rose

Love I this little flower?

Because its fragrant leaves are those

I loved in childhood's hour.

Though many a flower may win my praize, The violet has my love; .

I did not pass my childish days

In garden or in grove.

My garden was the window-seat,

Upon whose edge was set

A little vase-the fair, the sweet-

It was the violet.

It was my pleasure and my pride ;How I did watch its growth.

For health and bloom what plans I tried

And often injured both?

I placed it in the summer shower,

I placed it in the sun;

And ever at the evening hour,

My work seem'd half undone. 
The broad leaves spread, the small buds grew How slow they seem'd to be ! At last there came a tinge of blue, 'Twas worth the world to me?

At length the perfume fill'd the room, Shed from their purple wreath; No flower has now so rich a bloom, Has now so sweet a breath.

I gather'd two or three-they seem'd Such rich gifts to bestow!

So precious in my sight, I deem'd That all must think them so.

Ah! who is there but would be fain To be a child once more; If future years could bring again All that they brought before?

My heart's world has been lcng o'erthrown; It is no more of flowers ; Their bloom is pass'd, their breath is flown; Yet I recall those hours.

Let nature spread her loveliest, By spring or summer nurst: Yet still I love the vinlet best, Because I loved it first. 
TAE POETRY OF FLOW'ERS.

\section{F I E L D F L O W ER \$.}

\section{BY CAMPBELI}

YE field flowers! the gardens eelipse you, 'tis true, Yet, wildings of nature, I dote upon you,

For ye waft me to summers of old,

'When the earth teem'd around me with fairy delight,

And when daisies and buttercups gladden'd my sight,

Llke treasures of silver and gold.

I love you for lulling me baek into dreams of the blue Highland mountains and echoing streams,

And of birchen glades breathing their balm, While the deer was seen glaneing in sunshine remote,

Ard the deep mellow erush of the wood-pigeon s note

Made musie that sweeten'd the ealm.

Not a pastoral song has a pleasanter tune Than ye speak to my heart, little wildings of J une:

of old ruinous castles ye tell,

Where I thought it delightful your beauties to find,

When the magie of nature first breathed on my mind,

And your blossoms we te nart of the spell. 
Fven now what affeetions the violet awakes! What loved little islands, twiee seen in the: lakes,

Can the wild water-lily resture!

What landseapes I read in the primrose's looks, And what pietures of nebbled and minnowy brooks,

In the vetehes that tangled their shore !

Earth's culturcless buds, to my heart ve were dear,

Ere the fever of passion, or ague of fear,

Had scathed my existence's bloom;

Once I weleome you more, in life's passionlesa stage,

With the visions of youth to revisit my age, And I wish you to grow on my tomb. 


\title{
IN EASTERN LANDS.
}

\author{
BY. J. G. PERCIVAL.
}

is Eastern lands they talk in flowers, And they tell in a garland their loves and cares; Jach blossom that blooms in their garden bowers, On its leaves a mystic language bears.

I'he rose is a sign of joy and love, Young blushing love in its earliest dawn; And the mildness that suits the gentle dove From the myrtle's snowy' flower is drawn.

Innocence shines in the lily's bell,

Pure as the heart in its native heaven; Fame's bright star and glory's swell, By the glossy leaf of the bay are given.

The silent, soft, and humble heart

In the violet's lidden sweetness breathes; And the tender soul that cannot part, A twine of evergreen fondly wreathes.

The cypress that daily shades the grave, Is sorrow that mourns her bitter lot, And faith that a thousand ills can brave Speaks in thy blue leaves-forget-me-not

Then gather a wreath from the garden bowera. And tell the wis! of thy heart in flowers. 


\section{THE HONEYSUCKLE.}

BY THF COUNTESS OF BLESSINGTON،

SEE tlie honeysuckle twine

Round this casement:- 'tis a shrine

Where the heart doth incense give,

And the pure affections live

In the mother's gentle breast

By her smiling infant press'd.

Blessed shrine! dear, blissful home ! Source whenee happiness doth come! Round by the cheerful hearth we meet All things bcauteous-all things sweet Evcry solace of man's life, Mother, daugliter,-sister,-wife !

England, is!e of free and brave, Circled by the Atlantic wave! Though we seek the fairest land That the south wind ever fann'd, Yet we cannot hope to see IIomes so holy as in thee.

As the tortoise turns its head Towards its native ocean-bed, Howsoever far it be

From its own beloved sea, "ithus, dear Albion, cvermore Do we turn in scek thy shore' 


\section{TO A SNOW-DROP.}

BY LANGHORNE.

Poets still, in graceful numbers, May the glowing roses choose; But the snow-drop's simple beauty Better suits an humble muse.

Earliest bud that decks the garden,

Fairest of the fragrant race, First-born child of vernal Flora, Seeking mild thy lowly place;

Though no warm or murmuring zephys

Fan thy leaves with balmy wing, Pleased we hail thee, spotless blossom, Herald of the infant spring.

Through the cold and cheerless season Soft thy tender form expands, Safe in unaspiring graces,

Foremost of the blooming bands.

White-robed flower, in lonely beauty,

Rising from a wintry bed; Ehilling winds, and blasts ungenial, Rudely threat'ning round thy head. 
Silv'ry bud, thy pensile foliage Seems the angry blasts to fear; Yet seeure, thy tender texture Ornaments the rising year.

No warm tints, or vivid colouring, Paint thy bells with gaudy pride; Mildly charm'd we seek thy fragrances Where no thorns insidious hide.

Tis not thine, with flaunting beauty, To attraet the roving sight ; Nature from her varied wardrobe, Chose thy vest of purest white.

White as Jalls the fleeey shower, 'Thy soft form in sweetness grows; Not more fair the valley's treasure, Not more sweet her lily blows.

Drooping harbinger of Flora, Simply are thy blossoms drest; Artless as the gentle virtues Mansion'd in the blameless breast.

When to pure and timid virtue Friendship twines a votive wreatn, Q'er the fair seleeted garland 'I'hou thy perfume soft shalt breathe. 
TIE POETRY CF FLOWERS.

\section{TO THE PASSION-FI،OWER.}

\section{BY BERNARD BARTON.}

If Supcrstition's baneful art

First gave thy mystic name,

Reason, I trust, would stcel my hcart

Against its groundless claim;

But if, in fancy's pensive hour,

By grateful feclings stirr'd,

Her fond imaginative power

'That namc at first conferr'd-

Though lightly truth her flights may prizo,

By wild vagary driven,

For once their blameless excrcise

May surely be forgiven.

IVe roam the seas-give new-found isles

Some king's or conqueror's name :

We rcar on carth triumphant piles

As mceds of carthly fame :--

We soar to heaven; and to outlive

Our life's contractcd span,

Into the glorious stars we give

The names of mortal man : 
Then may not one poor floweret's bloom The holier menory share Of Him, who, to avert our doon, Vouchsafed our sins to bear?

God dwelleth not in temples rear'd By work of human hands, Yet shrines august, by men revered Are found in Christian lands.

And may not e'en a simple flower Proclain Ilis glorious praise, Whose fiat, only, had the power Its form from earth to raise?

Then freely let thy hlossom ope lts beauties-to recall

A scene which bids the humble hopes In Him who died for all! 
THE POETRY OF FIOWERS.

\section{TIE LILY OF THE VALLEY.}

\section{BY R.ISHOP MANT.}

Far flower, that, lapt in lowly glote, Dost hide beneath the greenwoud shade,

Than whom the vernal gale

None iairer wakes, on bank, or spray,

Our England's lily of the May,

Our lily of the vale!

Art thou that "Lily of the field,"

Which, when the Saviour sought to shield

The heart from blank despair,

He show'd to our mistrustful kind, An emilem of the thoughtful mind

Of God's paternal care?

Not this. I trow ; for brighter shiri

To the warm skies of Palestine

Those children of the East :

There, when mild autumn's early rair.

Descends on parch 'd Esdrela's plain,

And 'I'abor's oak-girt crest,

More frequent than the host of night, Those earth-born stars, as sages write, Their brilliant disks unfold; 
Fit symbol of imperial state, Their sceptre-seeming forms clate, And erowns of burnish'd goll.

But not the less, sweet spring-tide's flower, Dost thou display the Maker's power, His skill and handy work,

Our western valleys' humbler child, Where, in green nook of woodland wild, 'Thy modest blossoms lurk.

What though nor eare nor art be thine, 'The loom to ply, the thread to twine, Yet born to bloom and fade, Thee to a lovelier robe arrays, 'Than, e'en in Israel's brightest days, Her wealthiest kings arnay'd.

Of thy twin-leaves the embower'd sereen, Whieh wraps thee in thy shroud of green; 'I'hy Eusn-breathing smell; 'Thy areh'd and purple-vested stem, Whence pendent many a pearly gem, Displays a milk-white bell;

Instinet with life thy fibrous root, Which sends from earth the aseending shoot As rising from the dearl, And fills thy veins with verdant juice, Charged thy fair blossoms to produee. And berries srarlet red; 
The triple ccll, the two fold sced,

A ceaseless treasure-housc decrced,

Whence aye thy race may grow,

As from creation thcy have grown,

While spring shall wcave hcr flowery c5owrs

Or vernal breczes blow;

Who forms thee thus, with unsecn hand?

IVho at creation gave command,

And will'd thee thus to be ;

And keeps thee still in being, through

Age after age revolving! Who

But the great God is he?

Omnipotent, to work his will ;

Wise, who contrives each part to fill

'The post to cach assign'd ;

Still provident, with sleepless carc,

'I'o keep; to makc thee swect and fair

For man's eljoyment-kind!

"There is no God," the scnseless say :-

"O God! why cast'st thou us away?"

Of fecble faith and frail,

'I he mourner breathes his anxious thought;

By thec a bettcr lesson taushat,

Sweet lily of the vale !

Yes, He who made and fosters thee,

In reason's cye perforce 'nust be

Of majesty divine 
266 THE POLTR; OF TLUWEAS.

Nor deems she, that his guardian caso Will He in man's support forbear, Who thus provides for thine.

\section{THE FLOWER-GAKUEN.}

BY BARRY CORNWALE.

There the Rose unveils Her breast of beauty, and each delicate bud $\mathrm{O}^{\prime}$ the season eomes in turn to bloom and perish. But first of all the Violet, with an eye Blue as the midnight heavens; the frail Snow-drop, Born of the breath of winter, and on his brow Fix'd like a pale and solitary star; The languid Iryacinth and pale Primrose, And Daisy trodden down like modesty ; The Foxglove, in whose drooping bells the bee Makes her sweet music; the Narcissus, (named From him who died for love, the tangled Wood. bine,

Lilacs, and flowering Limes, and scented Thorns, And some from the volur tuous winds of June Catch their perfumings. 


\section{THE LANGUAGE OF' FLOWERS.}

\section{PART FIRST.}

Abecedary .......... Volubility.

Abatina .............Fickleness.

Acacia................ Friendskip.

Acacia, Rose or White. EZlegance.

Acacia, Yellow........ Secret love.

Acanthus........... The fine arts. Artifue.

Acalia...............Temperance.

Achillea Millefolia .....War.

Achimenes Cupreata... Such worth is rare.

Aconite (Wolfsbane).. Misanthropy.

Aconite, Crowfoot..... Lustre

Adonis, Flos......... Sad memories.

African Marigold...... Vulgar minds.

Agnus Castus......... Coldness, Indifference. Agrimony ........... Thankfulness. Gratitude. Almond (Common).....Stupidity. Indiscretion. Almond (Flowering).... Ilope.

Almond, Laurel......... Perfidy. Allspice ............ Compassion.

Aloe................ Grief. Religious superstition. 
Althra Frutex (Syrian Mallow) .............Persuasion.

Alyssum (Sweet)...... Worth beyond beauty. Amaranth (Globe)..... Immortality. Unfading love.

Amaranth (Coekseomb).............. Foppery. Affectation. Amaryllis.............. Pride. Timidity. Splen did beauty.

Ambrosia ............ Love returned. American Cowslip..... Divine beauty. Ameriean Flm ........ Patriotism. Ameriean Linden....... Matrimony. Ameriean Starwort... Welcome to a stranger. Cheerfulness in old age. Amethyst............Admiration. Andromeda............ Self-saerifice. Anemone (Zephyr

Flower) ............. Sickness. Expectation. Anemone (Garden)....Forsaken. Angeliea............. Inspiration, or Magic. Angree............... Roydlty. Aprieot (Blossom).... Doubt. Apple .............. Temptation. Apple (Blossom).......Preference. Fame speak thim great and good. Appie, Thorn........ Deceitful ehurms. Apoeynum (Dogsbane) Deceit. Arbor Vitæ.......... Unchanging friendstip Arum (Wake Robin).. Ardor. Zeal. Live for me. Ash-leaved Trumpet

Flower ............. Scparation. Ash, Monntain........ I'rullenee, or With me you are safe. 


\section{Ash Tree...........Grandeur.}

Aspen Tree............. Lamentation, or fear. Aster (China).......... Variety. Afterthought. Asphodel.............. My regrets follow you to the grave.

Auricula............Painting.

Auricula, Scarlet....... Avarice.

Austurtium............Splendor.

Azalea............... Temperance.

Bachelor's Buttons.... Celibacy.

Balm................ Sympathy.

Balm, Gentle..........Pleasantry.

Balm of Gilead......... Cure. Relief.

Balsam, Red........... Touch menot. Impatient resolves.

Balsam, Yellow....... Impatience.

Barberry ............. Sharpness of temper.

Basil ................ Hatred.

Bay Leaf............. I change but in death.

Bay (Rose) Rhododen-

dron............... Danger. Beware.

Bay Tree............... Glory.

Bay Wreath.......... Tleward of merit.

Bearded Cropis....... Protection.

Becch Tree........... Prosperity.

Bee Orehis............. Industry.

Bee Ophrys............Error.

Begonia............... Deformity.

Belladonna............. Silence. ITush!

Bell Flower, Pyramidal .

B

Flower (small

white) .............. Gratitude.

Constaney.

Belvedore ............ I declare against you. 
Betony ............. Surprise.

Bilberry................ Treachery.

Bindweed, Great....... Insinuation.

Bindweed, Small...... Humity. Huty.

Bireh.................. Meekness.

Birdsfoot, Trefoil...... Revenge.

Bittersweet; Nightshade ............ Truth.

Blaek Poplar........... Courage.

Blackthorn............ Difficulty.

Bladder Nut Tree...... Frivolity. Amusement. Bluebottle (Centaury). Delicacy.

Bluebell............. Constancy. Sorrouful re-

Blue-flowered Greek Valerian........... Rupture.

Bonus Ilenriens....... Goodness.

Borage .............. Bluntness.

Box Tree............. Stoicism.

Bramble.............. Lowliness. Envy. Remorse.

Braneh of Currants... You please all.

Branch of Thorns..... Severity. Rigor.

Bridal Rose........... IIappy Love.

Broom ............... Ihumility. Neatness.

Browallia Jamisonii ... Could you bear poverty?

Buckbean .......... Calm repose.

Bud of White Rose.... Ireart iynorance of love.

Buglos .............. Falsehood.

Bulrush .............. Indiscretion. Docility.

Bundle of Reeds, with

their Panieles.........Music,

Burdock ... ......... Importunity. Touch me not. 
Bur............. Rudeness. Tou veary me. Buttereup (Kingeup).. Ingratituds. Childishness. Butterfy Orehis...... Gayety. Butterfly Weed........ Let me go.

Cabbage ...........Profit.

Cacalia............. Llulation.

Cactus.............Warmth.

Calla Ethiopica...... Magnifucent beauty.

Calceolaria .........I offer you pecuniary assistance, or $I$ offer you my fortune.

Calycanthus ......... Benevolence.

Camellia Japonica,

Red .............. tupretending excellence.

Camellia Japonica,

White........... Perfected Loveliness.

Camomile. ........... Energy in adversity.

Campanula Pyamida. Aspiring.

Canary Grass.........Perseverance.

Candy tuft ............ Indifference.

Cantcrbury Bell.......Acknorvtedigment.

Cape Jasmine........ I am too happy.

Cardaminc............ Paternat error.

Carnation, Decp Red.. Alas! for my poor heart.

Carnation, Striped.... Refusal.

Carnation, Ycllow.... Disdivin.

Cardinal Flower....... Distinction.

Catchfly............. Snare.

Catchtly, Red............ Youthful love.

Catchfly, White........ Bstrayed.

Cattleya.............. Mature charms.

Cattleya Pineli......... Jatronly grace.

Cedar................ Strength.

Cedar of Lebanon..... Incorruptible. 
Cedar Leaf.......... I live for thee.

Celandine (Lesser).... etoys to come.

Cereus (Creeping)...... Modest genius.

Centaury ............ Delicacy.

Champignon...........Suspieion.

Cheekered Fritillary..Perseeution.

('herry Tree, White... Good education.

('herry Tree, White... Deeeption.

Chestnut Tree........ Do me justice.

('hinese Primrose..... Lasting love.

('hiekweed........... Rendezvous.

Chieeory ............ Frugality.

China Aster.......... Variety.

Chiva Aster, Double.. I partake your sentiments.

China Aster, Single... I will think of it.

China or Indian Pink. . Aversion.

China Rose.......... Beauty always new.

Chinese Chrysanthe- Cheerfulness under ad. mum ............ versity.

Chorozema Varium... . You have many lovers.

Christmas Rose....... Relieve my aniciety.

Chrysanthemum, Red.I love.

Chrysanthemum,

White ........... Truth.

Clurysanthemum, Yel-

low.............. Slighted love.

Cineraria............... Always delightful.

Cinquefoil ...........Maternal affection.

Cirear ..............spell.

(istus, or Roek Iiose.. Popular faror.

(istus, Gum.........I shull die to-morrow.

Citron............ Ill-natured beauty.

Clarhia............ The variety of your conversation delights me.

Clematis ........... Mental beauiy. 
Clematis, Evergreeu... Poverty.

Clianthus........... Worldliness. Self-seeking. Clotbur ............. Rudeness. Pertinacity. Clores............. Dignity.

Clover, Four-leared.... Be mine.

Clover, Red .......... Industry.

Clover, White ........Think of me.

Cobæa............... Gossip.

Cockscomb Amarantl. Foppery. Affectation.

Colchicum, or Meadow Singularity.

Sattron ..........My best days are past.

Coltsfoot ............ Tustice shall be done.

Columbine ............ Folly.

Columbine, Purple.... Resolved to win.

Columbine, Red........ Anxious and trembling.

Convolvulus ......... Bonds.

Convolvulus, Blue

(Minor)...........Repose. Niqht.

Convolvulus, Major... Extinquished hopes.

Conrolvulus, Pink.... Worth sustcined by judi rious and tender affection.

Corchorus ........... Impatient of absence.

Corcopsis ............ Always cheerful.

Corcopsis Arkansa.... Love at first sight.

Coriander ............ IIidden worth.

Corn .............. Riches.

Goris, Broken........ Quarrel.

Corn Straw............. Preement.

Corn Bottle.......... Delicacy.

Corn Cockle............ Gentility.

Cornel Trec.......... Duration.

Coronclla............ Success crown your wishes. Cosmelia Subra....... The charm of a blush. 
Cowslip...........Pensiveness.

Winning

Cowslip, Ameriean.... Divine beauty.

Crab (Blossom).......Ill nature.

Cranberry ............ Cure for heartache.

(reeping Cereus...... Itorror.

(ress ...............Stability. Power.

('roeus ................... Abuse not.

Crocus, Spring....... Youthful gladness.

Crocus, Siffron.........Mirth.

(rown, Imperial.......Majesty. Power.

(rowsbill............ Envy.

Crowfoot.............. Ingratitude.

Crowfoot (Aeonite-

leaved) ............ Lustre.

Cuckoo Plant..........Ardor.

Cudweed, Ameriean... Unceasing romembrance. Currant ............. Thy frown will kill me.

Cuseuta............ Meanness.

Cyelamen............. Diffidence.

Cypress ............ Death. NGourning.

I)afiorlil ............ Regard.

Dahlia ............. Instability.

Daisy ............... Innocence.

Daisy, Garden....... I I share your sentiments.

Daisy, Nichaelmas.... Fareweil, or afterthought.

Daisy, Party-colored.. Beauty.

Daisy, Wild.......... I will think of it.

Damask Rose........... Brilliant complexion.

Dandelion ............ Rustic oraclo.

Daphne................. Glory. Immortality.

Daphne Odora.......... Painting the lily.

Darnel .............Vice.

Dead Leares. .........Sadness. 
Deadly Nightshade.... Falsehood.

Dew P'lant.............A serenade.

Dianthus .............. Make haste.

Jiosma............... Your simple elegance

Dipteracanthus Speccharms me. tabilis............ Fortitude.

Diplademia Crassinoda .............. You are too bold.

Dittany of Crete....... Birth.

Dittany of Crete, White.............Passion.

Doek..................Patience.

Dodder of Thyme...... Baseness.

Dogsbane.............Deceit. Fatsehood.

J) ogwood............. Durability.

Dragon Plant.......... Snare.

Dragonwort ..........IIorror.

Dried Flax............. Utility.

Ebony Tree.......... Blackness.

Eehites Atropurpurea. Be warned in time. Eglantine (Sweetbrier) ............. Poetry. I wound to heal. Elder ................... Zealousness.

Elm................. Dignity.

Enchanters Nightshade ............ Wiuchcraft. Sorcery. Endive .. ............ Frugality. Escholzia............ Do not refuse me. Eupatorium........... Delay. Everflowering Candytuft ............... Indifference. Evergreen Clematis... Poverty. Evergreen Thorn..... Solace in adversity. 
Everlasting .......... Tever-ceasing remen brance.

Everlasting Pea....... Lasting plcasure.

Fennel ............ Forthy all praise. Strength.

Fern ............Fascination. Dragic. Sim cerity.

Fieoides, Iee Plant.... Your looks frece me.

Fig................. Argument.

Fig Marigold.......... Illeness.

Fig Tree............ Prolific.

Filbert ............Reconcitiation.

Fir ...............Time.

Fir Tree............Elcvation.

Flax ............ Domestic industry. Fate.

Flax-leaved GoldenIfeel your kindness. loeks ............Tardincss.

Fleur-de-lis .......... Flame. Iburn.

Fleur-de-linee ........Fire.

Flowering Fern.......Reverie.

Flowering Reed........ Confidence in ITeaven.

Flower-of-an-Hour .... Delicatc bcauty.

Fly Orehis........... Emror.

Flytrap............ Deceit.

Fool's Parsley.........Silliness.

Forget-Me-Not ....... True love.

Foxglove........... Insincerity.

Foxtail Grass.......... Sporting.

Franeiseea Latifolia... Beware of false friends.

Freneh Honeysuekle.. liustic becuty.

Freneh Marigold.......elealousy.

Freneh Willow ....... Brarery and humanity.

Frog Ophrys......... Disgust. 
Fuller's Teasel........Misanthropy. Fumitory ............... Spleen.

Fuehsia, Searlet...... Tuste.

Furze, or Gorse....... Love for all seasons.

Garden Anemone.....Forsalien.

Garden Chervil........ Sincerity.

Garden Daisy......... I partake your sentimentz.

Garden Marigold....... Uneasiness.

Garden Rauuneulus... You are rich in attractions.

Garden Sage..........Esteem.

Garland of Roses...... Revord of virtue.

rardenia ........... Refunement.

Germander Speedwell. Facility.

Geranium, Dark...... Melancholy.

Geranium, Horse-shoe

Leaf ............ Stupidity.

Ceranium, Ivy ......... Bridal facor.

Geranium, Lemon..... Unexpected mecting.

Geranium, Nutmeg.... Expected meeting.

Geranium, Oak-leaved. True friendship.

Geranium, Peneilled..Ingenuity.

Geranium, Rose-seent-

ed................Preference.

Geranium, Searlet.... Comforting.

Geranium, Silver-

leaved............. Recall.

Geranium, Wild.......Steadfast piety.

Gillyflower ........... Bonds of affection.

Gladioli............ Ready armed.

Glory Flower.......... Glorious beauty.

Goat's Rue..........Reason.

Golden Rod...........Precaution.

Gooseberry.............. 
Gourd...........Extent. Bulk.

Grammanthus Chlora-

flora.............. Your temper is too hasty. Grape, Wild.......... Charity.

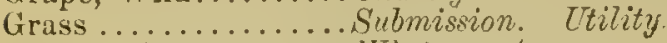

Guelder Rose........Winter. Age.

Hand Flower Tree.... Warning.

Harebell ............Submission. Girief.

Hawkweed..........Q Quieksightedness.

Hawthorn ...........Ilope.

Hazel..............Reenciliation.

Ileartsease, or Pansy.. Thoughts.

Heath .............. Solitude.

Helenium ..........Tears.

Heliotrope........... Devotion, or I turn $t$, thee.

Hellebore ..............Seandal. Calumny.

Helmet Flower (Monks-

hood)............ Fuight-errantry.

Hemloek ........... You will be my death.

Hemp............. Fate.

Ilenbawe ............. Imperfection.

Hepatiea .............. Confidence.

Hibiseus............. Delicate beauty.

II olly............... Foresight.

Iolly il erb.......... Enchantment.

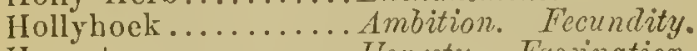
Hovesty.............. Ilonesty. Fascination. IIoney Flower........ Love sweet and secret.

I!oneysuekle .......... Generous and devoted af. fection.

Honeysuckle (Coral).. The color of my fate. Honeysuckle (French). Rustic beauty.

Hop.............. Injustice.

Iorubeam.......... Ornament. 
Horse Chestnut...... Lnxury.

Hortensia............ You are cold.

Housclcek ............ Vivacity. Domestic InHoustonia .......... Content.

IIoya............... Sculpture.

Hoyabella ........... Contentment.

Humble Plant.......... Despondency.

Hundred-leaved Rose. Dignity of mind.

Hyacinth.............Sport. Game. Play.

Hyacinth, Purplc..... Sorrowful.

Hyacinth, White...... Unobtrusive loveliness.

Hydrangea ............. A boaster.

Hyssop.............. Cleanliness.

Iccland Moss........ Health.

Ice Plant............ Your looks freeze me.

Imbricata........... Tpriyhtness. Sentiments of honor.

Inperial Montague.... Power.

Indian Cress.......... Warlike trophy.

Indian Jasmine (Ipo-

moa) ..............Attachment.

Indian Pink (1)ouble).. Always lovely.

Indian Plum..........Privation.

Jis................ Message.

Iris, German........... Flame.

Iry............... Friendship. Fidelity.

Ivr, Sprig of, with

Marriage.

'T'endrils............Assiduous to please.

Jacob's Iadder....... Come down.

Japan Rose......... Beauty is your only attraction. 
Jasmiue............Amiability.

Jasmine, Cape......... Transport of joy.

Jasmine, Carolina..... Separation.

Jasmine, Indian....... I attach myself to you.

Jasmine, Spanish.......Sensuality.

Jasmine, Yellow...... Grace and elegance.

Jonquil.............. I desire a return of af-

Juniper................ Succor. Protection.

Justicia ............ The perfection of female

loveliness.

Kennedia........... Mental beauty.

King-eups ............ Desire of riches.

Jaburnum.......... Forsaken. Pensice

Lady's Slipper........ Capricious beauty.

Wil

ingerstræmia, Indian. Eloquence.

me and wear me.

Lintana ............... Rigor.

Lapageria hosea....... Thene is no unalloyed

good.

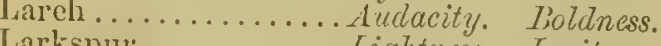

Larkspur............ Lightness. Levity.

Larkspur, Pink........Fickleness.

Larkspur, Purple......Ilaughtiness.

Isaurel ............Glory.

Laurel, Common, in

flower ........... Perfidy.

Isaurel, Ground.........Perseverance.

Laurel, Mountain....... Ambition.

Laurel-leaved Hag-

nolia ............ Iignity. 
Laurestina .........A token. Lavender........... Distrust. Leaves (dead)......... Melancholy. Lemon ............. Zest. I cem on Blossoms...... Fidclity in love. Lesehenaultia Splen-

dens............ You are charming. Letruce ............ Cold-heartedness. Liehen ............. Dejection. Ślitude. Lilac, Field.......... Mrunility. Lilac, Purple......... First conotions of love. Lilae, White.......... Touthful innocence. Lily, Day ............. Coquetry. Lily, Imperial.......... Majesty. Ijily, White......... Purity. Swectness. I.ily, Yellow............ Falschood. Gayety. Lily of the Valley.....Return of happiness. UnLinden or time Trees. Conjugal love. Lint.............. I feel my obligations. Live Oak............. Liberty. Liverwort ............. Confidenec. Liquorice, Wild........I declarc against you. Jobelia............... Malcvolence.

Locust Tree............. Elegance. Locust Tree (green).... Affection beyond the grave. Isondon Pride......... Frivolity.

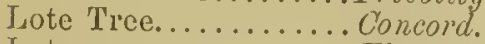
J otus. ...............Eloquence. I otus Flower............ Estranged love. Lotus Leaf. .......... Recantation. Love in a Mist......... Perplexity. Love lies Bleeding...... Hopeless, not heartless. Luecrn ............. Life. Lupine ............. Foraciousness. 
Madder............ Calumny.

Magnolia ................ Love of Nature.

Magnolia, Swamp.....Persevcrance.

Jallow .............. Mrildness.

Mallow, Marsh..........Beneficence.

Mallow, Syrian.......... Consumed by lorc.

Mallow, Venetian...... Delicate beauty.

Malon Creeana....... Will you share my for

Manehineal Tree......Falsehood.

Manörake........... IIorror.

Maple............ Reserve.

Iarianthus . . . . . . Hope for better days.

Marigold ............ Grief.

Marigold, African..... Vulgar minds.

Marigold, Freneh........ tealousy.

Marigold, Prophetic.... Prediction.

Marigold and Cypress. Despair.

Marjoram............Blushes.

Marvel of Peru....... Timidity.

Meadow Lyehnis...... Wit.

Meadow Saffron........My best days are past.

Meadowsweet ........ Uselessness.

Mereury............ Goodness.

Mesembryanthemum .. Iuleness.

Mezereon............ Desire to please.

Miehaelmas Daisy...... Afterthought.

Mignonette ......... Your quatities surpass

Milfoil........... War.

Milkveteh........... Your presence softens $m y$

Milkwort .......... rermitage.

Mimosa (Sensitive

Plant) ............. Sensitiveness. 
Mint............. Virtue.

Mistletoe ...........I surmount difficulties.

Mitraria Coccinea..... Indolence. Dulness.

Moek Orange......... Counterfeit.

Jonarda Amplexi-

caulis............ Your whims are quite unbearable.

Monkshood .........A deally foe is near.

Jonkshood (Helmet

Flower).......... Chival'y. Krnight-er.

rantry.

Moonwort.......... Forgetfulness.

Morning Glory.........Affectation.

Moschatel ..........Weakness.

Moss............... Maternal love.

Mosses..............Ennui.

Mossy Saxifrage......Affection.

Motherwort.......... Cancealed love.

Mountain Ash......... Prudence.

Mourning Bride....... Unfortunate attachment.

Mouse-eared ChiekI have lost all.

weed.............. Ingenuous simplicity. Jouse-eared Seorpion grass............. Forget me not.

Moving Plant............ Agitation.

Mudwort .............Mappiness. Tranquillity. IIulborry Tree (Blaek). I sliall not snrvivo you. Mulberry Tree (White). Wisilom.

Mushroom..........Suspicion, or I can't en. tirely trust you.

Musk Plant..........Weakness.

Mustard Seed.........Indifference.

Myrobalan...........Privation.

Myrrb............G!adness. 
Myrtle............ Love.

Nareissus ..........Egotism.

Nasturtium ........... Putriotism.

Nemophila ........... Success everywhere.

Nettle, Common Stinging.............. You are spiteful.

Nettle, Burning........S Slander.

Nettle Tree..........Conceit.

Night-blooming Cereus............. Transient beauty.

Night Convolvulus.... Night.

Nightshade......... Falsehood.

Oak Leares.......... Bravery.

Oak Tree.............. IIospitality.

Ouk (White).......... Independence.

Oats.............. The witching soul of

Oleander ............ Beverare. music.

Olive ............... P'eace.

Orange Blossoms..... Your purity equals your lovetiness.

Orange Flowers....... Chastity. Bridal festivities.

Orange Tree......... Generosity.

Orehis .............. A belle.

Osier ................ Frankness.

Osinunda ............ Dreams.

Ox Eye.............Putience.

Palm .............. Victory.

Pansy ................... Thoughtits.

Parsley ................ Festivity.

Pasque Flower........ You have no claims. 
Passion Flower....... Reliqious superstition, when the flower is rePatienee Doek........Putience. versed, or Faith if erect. Pea, Everlasting......A. An appointed meeting. Lasting pleasur'o.

Pea, Swect......... Departure.

Peach ................ Your qualities, like your charms, are unequalled.

Peach Blossom....... I am your' captive.

Pear................Affection.

Pear Tree............ Comfort.

Fenstemon Azureum.... Iligh-bred.

Pennyroyal............ Flee away.

Peony ............... Shame. Bashfulness.

Peppermint.......... Warmth of feeling.

Periwinkle, Blue...... Early friendship.

Periwinkle, White..... P'easures of memory.

Persicaria............ Restoration.

Persimon............ biury me amid Nature's beauties.

Perurian IIeliotrope... Devotion.

Petunia ............... Your presence soothes me. Pheasant's Eye....... R'emembrance.

Phlox .............. Unanimity.

Pigeon Berry......... Indifference.

Pimpernel............ Change. Assignation.

Pine................ P'ity.

Pine-appie.............. Fou are perfect.

Pine, Piteh........... Philosophy.

Pine, Spruce.......... IIope in adversity.

Pink .............. Bohalness.

Pink, Curnation....... Woman's love.

Pink, Indian, Double.. Always lovely.

Pink, Indian, single...Aversion. 
Pink, Mountain .......Aspiring.

Pink, Red, Double.... Pure and ardent love.

Pink, Single........... Pure love.

Pink, Variegated.......Refusal.

Pink, White..........Ingeniousness. Talent. Plantain............ White man's footsteps.

Plane Tree............ Genizs.

Plum, Indian............Privation.

Plum Tree............. Fidelity.

Plum, Wild............ Independenee.

Plumbago Larpenta.... Holy wishes.

Polyanthus .......... Pide of riches.

Polyanthus, Crinison.. The heart's mystery.

Polyanthus, Lilac..... Confidenee.

Pomegranate ........... Foolishness.

Pomegranate Flower. Mature elegance.

Poor Robin.......... Compensation, $\theta \gamma^{\circ}$ an

Poplar, equivalent. equivalen

Poplar, White..........Time.

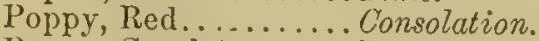

Poppy, Scarlet........... Fantastie extravagunee.

Poppy, White............Sleep. My bane.

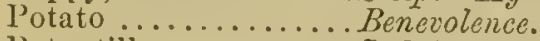

Potentilla............. I elaim, at least, your

Prickly Pear.......... Satire. esteem.

Pride of China......... Dissension.

Primrose ............. Early youth and sadness.

Primrose, Evening.... Ineonstancy.

Primrose, Red........ Unpatronized merit.

Privet............... Prohibition.

Purple Clover........ Provident.

Pyrus Japonica. . . . . . Fairies' fire. 
Quaking-grass .........Agitation. Quamoclit............Busybody.

Queen's Rocket....... You are the queen of coquettes. Fashion.

Quinee ............Temptation.

Ragged-robin.......Wit.

Ranunculus.......... You are radiant with charms.

Ranuneulus, Grarden.. You are rich in attractions.

Ranunculus, Wild...... Ingratitude.

Haspberry.......... Remorse.

liay Grass.......... Vice.

Red Catchfly......... Youthful love.

Reed.............. Complaisance. Mhric. Reed, Split............. Indiscretion.

Rhododendron (Rosebay)............... Danger. Lieware. Rhubarb.................. Advice.

Rocket.............Rivalry.

Rose............... Love.

Rose, Austrian....... Thou art all that is lovely.

Rose, Bridal...........Happy love.

Rose, Burgundy ...... Unconscious beauty.

Rose, Cabbage..........Ambassador of love.

Rose, Campion........ Only deserve my love.

Rose, Caroliua........ Love is dangerous.

Rose, China ......... Beauty always new.

Rosc, Christuras ...... Tranquillize my anxiety

Rose, Jaily.......... Thy smile $I$ aspire to.

Rosc, Damask ......... Brilliant complexion.

Rose, Decp Red....... Bashful shame.

Rose, Dog............. P'easure and pain.

Rose, Guelder ........ Winter. Age. 
Rose, Hundred-leaved. Pride.

Rose, Japan ......... Bearty is your only attraction.

Rose, Maiden Blush... If you love me you will

Rose, Montiflora ...... Grace.

Rose, Mnndi......... Variety.

Rose, Musk........... Capricious beauty.

Rose, Musk, Cluster... Ctharming.

Rose, Single.......... Simplieity.

Rose, Thornless........... Early attachment.

Rose, Unique ......... Call me not beautiful.

Rose, White ......... I am worthy of you.

Rose, White (with-

eled)............ Transient impressions.

Rose, Yellow ......... Decrease of love. Jealousy.

Rose, York and Lan-

caster........... War.

Rose, Full-blown,

plaeed over two

Buds .............. Secrecy.

Rose, White and Red

together.......... Unity.

Roses, Clown of ...... Reward of virtue.

Rosebud, Red.......... Pure and lovely.

Rosebud, White.......Girlhood.

Rosebud, Moss........ Confession of love.

Rosebud (Rhododen-

drou)............. Beware. Danger.

Rosemary ..........Remembrance.

Rudbeckia..........Justice.

Rue ............... Disdain.

Rush............ Docility.

Rye Grass........... Changeculle disposition 
Saffion ............. Beware of exeess.

Saffron Croeus........ Mirth.

Saffrou. Meadow...... Jy happiest days are past. Sage ............. Domestie virtue.

Sage, Garden.........Esteem.

Sainfoin ............... Aitation.

Saint John's Wort....Animosity

Salvia, Blue........Wisdom.

Salvia, Red...........Energy.

Saxifrage, Mossy......Affection.

Seabious ............ Un fortunate love.

Seabious, Sweet...... Widowhood.

Searlet Lyehais........ Sunbeaming eyes.

Sehinus ...........Religious enthusiasm.

Seoteh Fir..........Elevation.

Sensitive Plant....... Sensibitity.

Senry ............ Indifierenee.

Shaniroek ............. Light-heartedness.

Shepherd's Purse...... I offer you my all.

Siphoeampylos ....... Resolved to be noticed.

Snakesfoot..........IIorror.

Snapdragon ..........Presumption, also "No.'

Snowball ............... Bound.

Snowdrop ........... Irope.

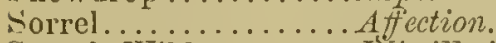

Sorrel, ivild........... IV it ill-timed.

Sorrel, Wood.........Joy.

Southernwood ........Jest. Bantering.

Spanish Jasmine...... Sensuality.

Spearmint......... Warmeth of sentiment.

speedwell .......... Female filletity.

speedwell, Germander. Faoility.

Speedwell, Spiked....Semblanee.

Spider Ophrys........Adroitness.

Spiderwort........... Esteem, not love. 
Spiked Willow Hcrb.. Prctension.

Spindle Tree......... Your charms arc engraven

Star of Bethlehem..... Purity. on my heart.

Starwort............ Afterthought.

Starwort, Anerican... Cheerfulness in old agc. Stephanotis..........Will you accompany rne to the East?

Stock .............. Lasting beauty.

Stock, Ten Week....Promptness.

Stoncerop ........... Tranquillity.

Straw, Broken........Rupture of a contract.

Straw, Whole........ Union.

Strawberry Blossoms.. Foresight.

Strawberry Trec...... Estcem, not love.

Sultan, Lilac......... If forgive you.

Sultan, Whitc........ Sweetness.

Sultan, Ycllow........ Contempt.

Sumach, Venice.......Splendor.

Sunflower, Dwarf......Adoration.

Sunflower, T'all........ Haughtiness.

Swallow-wort......... Cure for heartache.

Swect Basil.......... Good wishes.

Sweetbricr, American. Simplicity.

Sweetbrier, European. I wound to heal.

Sweetbrier, Ycllow.... Decrease of love.

Swcet Pea........... Delicate pleasures.

Sweet Sultan.........Felicity.

Sweet William........ Gallantmy.

Sycamore............... Curiosity.

Syringa .............. Memory.

Syringa, Carolina..... Disappointment.

Tamarisk........... Crime.

Tansy (Wild).......I d "c? are war against you. 
Teasel...............Misanthropy.

Tendrils of Climbing

Plants............. Ties.

Thistle, Common....... Austerity.

Thistle, Fuller's......... Misanthropy.

Thistle, Scotch........ Retaliation.

Thorn Apple.......... Deceitful charms.

Thorn, Branch of..... Severity.

Thrift ...............Sympathy.

Throatwort .............. Neglected beauty.

Thyme ............... Activity or courage.

Tiger Flower........... For once may pride be-

Traveller's Joy....... Safety. firiend the.

Tree of Life.......... Old age.

Trefoil ................ Revenge.

Tremella Ncstoe....... Resistance.

Trillium Pictum ......... Modest beauty.

Triptilion Spinosum.... Be prudent.

Truffle ............... Surprise.

Trumpet Flower....... Fame.

Tuberose ............. Dangerous pleasures.

Tulip, Red........... Declaration of love.

Tulip, Variegated...... Beautiful eyes.

Tulip, Yellow.......... Hopeless love.

- Turnip ................. Charity.

Tussilage (Sweet-

scented)............ Justice shall be done you.

Valerian ...........An accommodating dispo.

Valerian, Greek....... Rupture.

Veniee Sumach........ Intellectual excellence.

Splendor.

Venus's Car.......... Fly with me. 
Venus's Looking-glass. Flattery.

Venus's Trap ......... Deeeit.

Verbena, Pink........ Family union.

Verbena, Searlet...... Unite against evil, or Chureh unity.

Verbena, White...... Pray, for me.

Vernal Grass...........Poor, but happy.

Veronica .............. Fidelity.

Veronica Speeiosa .....Keep this for my sake.

Vervain ............Enchantment.

Vine ............... Intoxication.

Violet, Blue .......... Faithfulness.

Violet, Dame .........Watehfulness.

Violet, Sweet.........Modesty.

Violet, Yellow ........ Rural happiness.

Virginia Creeper...... I cling to you both in sum shine and shade.

Virgin's Bower....... Filial love.

Viscaria Oculata...... Will you danee with me?

Volkamenia........... May you be happy.

Walnut ............ Intellect. Stratagem. Wall-flower............ Fidelity in adversity.

Wateher by the Way-

side................ Never despair.

Water Lily ............. Purity of heart.

Water Melon............ Bulkiness.

Wax Plant.............Susceptibility.

Wheat Stalk..........Riches.

Whin .............. Anger.

White Jasmine........ Amiability.

White Lily .......... Purtty and modesty.

White Mullein ......... Good-nature.

White 0 ak............ Independence.

White Pink.......... Talent. 
White Poplar .........Time.

White Rose (dried).... Death preferable to loss of

Whortleberry........ Treason. innoeence.

Willow, Creeping ....... Love forsaken.

Willow, Water.........Fredom.

Willow, Weeping ....... Mourning.

Willow Herb......... Pretension.

Willow, French.......... Bravery and humanity.

Winter Cherry......... Dcception.

Wisteria ............. Welcome, fair stranger.

Witch Hazel............ spell.

Woodbine ............... Fraternal love.

Wood Sorrel...........Joy. Maternal tenderness.

Wormwood............. Absenec.

Tanthium ........... Rudeness. Pertinacity.

Xeranthemum .......... Cheerfulness under ailversity.

Yew................. Sorrow.

Zephyr Flower........ Expectation.

Zinnia ............. Thoughts of absent friends. 


\section{PART SECOND.}

Absence............ Wormwood.

Abuse not........... Chocus.

Acknowledgment ..... Canterbury Beld.

Activity, or Courage.. Thyme.

$\Lambda$ deadly foe is near... Mronkshood.

Admiration........... Amethyst.

Adoration ........... Dwarf Sunflower.

Adroitness ............ Spider: Ophrys.

Adulation.............. Cacalia.

Advice............. Rhubarb.

Afrection ............ Mlossy Saxifrage.

Affection ............ Pear?.

Affection ............ Sorrel.

Affection beyond the

grave............. Green Locust.

Affection, maternal.... Cinquefoil.

Affcetation............ Cockscomb Amarant及.

Affectation.............Morning Glomy.

Afterthought............ Michaelmas Daisy.

Afterthought.......... Starwort.

Afterthought ........... China Aster.

Agreement ........... Straw.

Age ................ Guelder Rose.

Agitatiou............... Moving Plant.

Agitation............ Sainfoin.

$\Lambda$ las! for my poor

heart.............. Deep Red Carnation. Always cheerful........ Coreopsis. 
Always lovely......... Indian Pink (double).

Always delightful...... Cineraria.

$\Lambda$ mbassador of love... Cabbage Rose.

Amiability.......... Jasmine.

Anger............Whin, ar Garse.

Inimosity ...........St. Jahn's Wart.

Antieipation.......... Gooseberry.

Anxious and trembling. Red Columbine.

Ardor, Zeal...........Cuckao Plant. Arum.

Argument ..........F

Ar'ts, or Artifiee........Acanthus.

Assiduous to please... Sprig of ivy with tendrits.

Assignation.......... Pimpernel.

Attaehment..........Indian Jasmine.

Audacity ............Larch.

Avarice ............ Scarlet Auricula.

Aversion ...........China, or Indian Pink.

Bantering ............ Southernwood.

Baseness ........... Dodder of Thyme.

Bashfulness.......... Peany.

Bashful shame....... Deep Red Rose.

Be prudent.......... Triptilian Spinasum.

Be warned in time..... Echites Atro-purpurea.

Beautiful eyes........ Variegated Tulip.

Beauty ............... Parti-colored Daisy.

Beauty always uew.... Clina Rose.

Beauty, eaprieious.... Lady's Slipper.

Beauty, caprieious ..... Musk Rose.

Beauty, delieate ....... Flower of an hour.

Beauty, delicate......IItibiscus.

Beauty, divine........... American Cawslip.

Beauty, glorious....... Glary Flower.

Beauty, lasting ......... Stock.

Beauty, magnificent... Colla Athiopica. 
Beauty, mental ........ Clematis.

Beauty, modest....... Trillium Pietum.

13eauty, negleeted..... Throatwort.

Beauty, pensive.......Laburnum.

Beauty, rustie ......... French Moneysuckle.

Beauty, uneonseious... Burgundy Rose.

Beauty is your only

attraetion.........Japan Rose.

Belle ............... Orehis.

Be mine.............Four-leaved Clover.

Benefieenee...........Marshmaillow.

Benerolenee........... Potato.

Betrayed ............ White Catehfly.

Beware................. Oleander.

Beware............. Rosebay.

Beware of a false

friend ............. Franciseea Latifolia.

Blackness ............. Ebony Tiee.

Bluntness .......... Borage.

Blushes ............... Marjoram.

Boaster................. Irangea.

Boldness ........... Pink.

Bonds............... Convolvulus.

Bonds of Affeetion.... Gillyflower.

Bravery ............ Oak Leaves.

Bravery and humanity. Freneh Willow.

Bridal favor......... Ivy Geranium.

Brilliant eomplexion. . Damask Ros6.

Bulk............ Water Melon

Bulk ............... Gourd.

Busybody ............ Quamoclit.

Bury me amid $\mathrm{Na}$ -

ture's beauties......Persimmon.

Call me not beautiful. . Rose Unique. 
Calm repose ......... Buekbean.

Calumny ............ Hellebore.

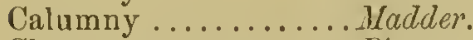

Change.............. Pimpernel.

Changeable disposition.............. Rye Grass.

Charity ........... Turnip.

Charming.............. Cluster of Musk Roses.

Charms, deceitful..... Thorn Apple.

Cheerfulness in old age............... Anerican Stamoort.

Cheerfulness under adversity .......... Chinese Chrysanthemum.

Chivalry ............honkshood.

Cleanliness .......... IIyssop.

Coldheartedness ....... Lettuce.

Coldness ...........Agnus Castus.

Color of iny life...... Coral Honeysuckle.

Come down............Jacob's Ladder.

Comfort............Pear Tree.

Comforting ............Scarlet Geranium.

Compassion ........... Allspice.

Concealed love........ Motherwort.

Coneert ............. Netrle Tree.

Concord............ Lote Tree.

Confession of lore..... Moss Rosebud.

Confidense ...........Hepatica.

Confidenee ............ Lilac Polyanthus.

Confidence............ Liverwort.

Confidenee in Heaven. Flowering Reed.

Conjugal lore......... Lime or Linden Tree.

Consolation...........Red Poppy.

Constancy............. Bluebetl.

Consumed by love.... Syrian Mallow.

Contentment......... Itoyabella. 
Could you bear porerty.............. Browallia Jamisoniz. Counterfeit............ Mock Orange. Cournge............. Blaek Poplar.

Crime ............... Tamarisk.

Cure ................ Balm of Gilead.

Cure for heartaehe.... Swallow-wort. Curiosity ..............Syeamore.

J)anger............. Khododendron Rosebay. Dangerous pleasures. . Tuberose. Death .............. Cypress.

Death preferable to Ioss of in noeenee... White Rose (dried). Deeeit...............Apocynum.

Deeeit............... Flytrap.

Deeeit...............Dogsbane.

Deeeitful eharms........ Apple, Thorn.

Deeeption ........... White Cherry Tree. Deelaration of love.... Red Tulip.

Deerease of love..... Kellow Rose.

Deformed ............Bcgonia. Dejeetion.............Lichen.

Delay ............... Eupatorium. Delieaey .............. Bluebottle. Centaury. Desire to pleaso........ Mezereon. Despair ............. Cypress. Despondeney ..........Humble Plant. Devotion, or I turn to thee............. Pcrurian Hcliotrope. Diffieulty ............. Blackthorn.

Dignity................. Cloves.

Dignity.............. Laurel-leaved Magnotia. 1)isappointment....... Syringa, Carolina. 1)isdnin............. Yellow Carnation. 
Disdain............ Rue.

Disgust .............. Frog Ophrys.

1)issension.............. Pride of China.

Distinction .......... Cardinal Flower.

Distrust ............ Lavender.

Divine beauty............ American Coroslip.

Docility ........... Rush.

Domestic industry.... Flax.

Domestic virtue...... Sage.

Do not despise my

poverty............ Shepherd's Purse.

Do not refuse me....... Eschcolzia, or Currot Flower.

Doubt............Apricot Blossom.

Durability .......... Dogwoood.

Duration .............Cornel Tree.

Early attachment..... Thornless Rose.

Early friendship ....... Blue Periwinkle.

Early youth .......... Primrose.

Elegance ............ Locust Tree.

Elegance and grace... Yellow Jasmino.

Elevation............ Scotch Fir.

Eloquence ............ Indian Lagerstrcemia.

Enchantment...........IIolly ITer.

Enchantment.......... Vervain.

Energy..............Red Salvia.

Energy in adversity... Camomile.

Envy............... Bramble.

Error................ Bee Orchis.

Error................. Ily Orchis.

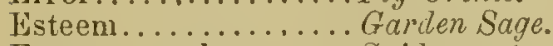

Esteem, not love..... Spiderwort.

Fisteem, not love...... Strawberry True.

Fistranged love........ Totus IFlower. 
Exeellenee.......... Camellia Japoniea.

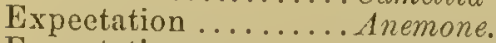

Expeetation ............. Zephyr Flower.

Expeeted meeting...... Nutmeg Geranium.

Extent ............ Gourd.

Extinguished hopes... Major Conrolvulus.

Faeility ............. Germander Speedwell.

Fairies' Fire.............. Pymus Japonzca.

Faithfulness .......... Blue Violet.

Faithfulness ............ Ieliotrope.

Falsehood ............... Bugloss. Deadly Night.

Falsehood .......... Yellow Lity.

Falsehood ........................

Fame ................. Tulip.

l'ame speaks him

great and good..... Apple Blossom.

Family union......... Pink Verbena.

Fantastie extrava-

ganee............. Scarlet Poppy.

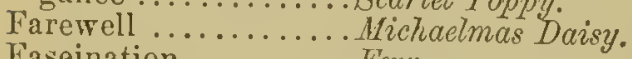

Faseination................ Fern.

Faseination........... Ilonesty.

Fashion .............. Queen's Roeket.

liceundity .............. Ilollyhock.

Felieity ............ Sweet Sultan.

Female fidelity.......... Speedwell.

Festivity ........... Parsley.

Fiekleness ................

Fiekleness .............. Pink Larkspur.

Fidelity............. Veronica. Ivy.

Fidelity.............. Plum Tree.

Fidelity in adversity... Wall.flower.

Fidelity in love....... Lemon Blossoms. 
Filial love........... Virgin's Bower. Fire ................ Fleur-de-Luce.

First emotions of love. Purple Lilae.

Flame .............. Fleur-de-lis. Iris.

Flattery ............. Venus's Looking-glass.

Flee away .............Pennyroyal.

Fly with me.......... Venus's Car.

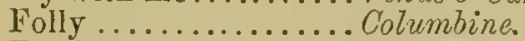

Foolishness........... Pomegranate.

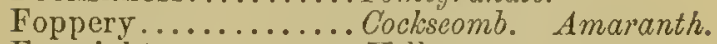

Foresight............ Itolly.

Forgetfulness ..........Moonwoort.

Forget me not........... Forget-Me-Not.

For once may pride

befriend me......... Tiger Flower.

Forsaken ............ Gavden Ancmone.

Forsaken ............Laburnum.

Fortitude............ Dipteracanthus Specta-

bilis.

Frankness ........... Osier.

Fraternal love........ Woodbine.

Freedom.............Water Willows.

Freshness .......... Damask Rose.

Friendship ............Aeacia. Ivy.

Friendship, early...... Ilue Periwinkle.

Friendship, true ...... Oak-leaved Geranium.

Friendship, unehang-

ing ............... Arbor Vite.

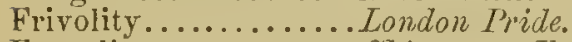

Frugality .............. Chiccory. Endivc.

Gallantry............ Sweet William.

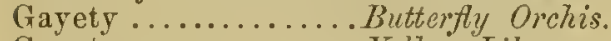

Gayety .............. Yellow Lily.

Generosity.......... Orange Tree. 
Generous and devoted affection........... French Honeysuckle. Genius ............. Plane Trce. Gentility............. Corn Cockle. Girlhood............. IFtite Rosebud. Give me your good wishes............. Sweet Busil.

Gladness .......... Nyyrh.

Glory .............. Laurel.

Glory. Immortality... Daphne.

Glorious beauty....... Glory Flower.

Goodness. . . . . . . . Bonus Henricus.

Goodness..............Mercury.

Good education ............. Cherry Tree.

Good wishes.......... Sweet Basil.

Good-nature .......... Whitc Mullein.

Gossip............... Cobcea.

Grace ............... Mlultiflora Rose.

Grace and elcganee.... Yellow Jasmine.

Grandeur............Ash Tree.

Gratitude............... Small White Bcll-flower.

Grief ............. Itarebcll.

Grief ............... Marigold.

Happy love......... Bridal Rosc.

Hatred ............................

Haughtiness ........... Purple Larlspur.

Haughtiness ........... Tall Sunflower.

Health ............. Ieland Moss.

Hermitagc............ Milkrvort.

Hidden worth ......... Coriander.

High-bred ........... Penstemon Azureum,

Holy wishes........... Plumbago Larpenta.

Honesty............ Honesty.

Hope.............. Flowering Almond. 
Hope...............Ifawthorn. Hope................ Snowdrop.

II ope in adversity..... Spruce Pine. IIopeless love......... Y Ellow Tulip. IIopeless, not lieartless ............. Love Lies Bleeding. Horror .............Mandrake.

Horror ............. Dragonswort. Horror .............. Snakesfoot. Hospitality .......... Oak Tree. II umility ............. Broom. Humility ............ Small Bindroeed. Humility ........... Field Lilac.

I am too happy....... Cape Jasmine.

I an your captire..... Peach Blossom.

I am worthy of you... White Rose.

I change but in death. Bay Leaf.

I claim at least your esteem ............ Potentilla.

I dare not............ Veroniea Speeiosa.

I declare against you... Belvidere.

I declare against you. . Liquoriee.

I declarc war against you............. Wild Tansy.

I die if neglected...... Laurestina.

I desire a return of affection............ Jonquil.

I feel my obligations... Lint.

I feel your kindness... Flax.

I have lost all......... Arourning Bride.

I live for thee......... Cedar Leaf.

I love .............. Red Chrysanthemam. I offer you my all..... Shepherd's Purse. 
I otfer you my fortune, or I offer you peeuniary aid ........... Calceolaria.

I share your sentiments ............ Double China Aster.

I share your sentiments ........... Garden Daisy.

I shall die to-morrow.. Gum Cistus.

I shall not survive you. Black Mulberry.

I surmount difficulties. Mistletoe.

I wateh over you...... Mountain Ast.

I weep for you.........Purple Verbena. I will think of it....... Single China Aster. I will think of it....... IVild Daisy.

I wound to heal........ Eglantine (Sucetbrier). Idleness .............. Mesembryanthemum. If you love me, you will find it out..........Maiden Blush Rose. Ill-nature............ Crab Blossom. Ill-natured beauty..... Citron. Imagination .......... Lupinc. Immortality ............. Globe Amaranth. Impatienee.......... Yellow Balsam. Impatient of absence.. Corchorus. Impatient resolves.... Red Balsam. Imperfeetion..........IIenbane. Importunity .......... Burdock. Ineonstancy ........... Evening Primrose. Ineorruptible.......... Cedar of Lebanon. Independence........ Wild Plum Tree. Independenee........ White Oak. Indifference........... Everflowering Candytuft. Indifference........... Mustard $S^{Y} e c d$. Indifferenee........... Pigeon Berry. Indifferenee..........Senvy. 
Indiscretion ......... Split Reed.

Indoleuee.............. IItraria Coccineu.

Indnstry.............. Red Clover.

Indnstry, Domestic...Frax.

Ingeniousness........ White Pink.

Ingenuity...............Pencilled Geranium.

Ingeuuous simplicity... Mouse-eared Chickweed.

Ingratituad ........... Crowfoot.

Innoeenee............ Daisy.

Insincerity.............. Foxglove.

Insinuation ............. Great Bindweèd.

Inspiration ............ Anyelica.

Iustability............ Dahlia.

Intellect............. Walnut.

Intoxieation .......... Vine.

Irony .............. Sardony.

Jealousy............. French MFarigold.

Jcalousy.............. Yellow Rose.

Jest ................ Southernwood.

Joy ................. Wood S'orrel.

Joys to come........... Lesser Celandine. Justiee............... Riudbeckia.

Justiee shall be done

to you............. Coltsfoot, or Sweet-scentea Tussilage.

Keep your promise.... Petunia.

Kindness............ Scarlet Geranium.

Knight-errantry........ Ilelmet Flover (Monksloovd).

Lamentation..........Aspen Tree.

Lasting beauty........... Stock.

Lasting pleasures...... Everlasting $P_{t} \alpha$. 
Let me go.......... Butterfy Wheel.

Levity............... Larkspur.

Liberty ............... Live Oak.

Life ..............Lucorn.

Lightheartedness...... Shamrock.

Lightness............ Larkspur.

Live for me............ Arbor Vitce.

Love..................Myrtle.

Love................Rose.

Love, forsaken........ Creeping Willow.

Love, returned.......... Ambrosia.

Love is dangerous..... Carolina Rose.

Love for all seasons... Furze.

Lustre ...............Aconite-leaved Crowfoot, or Fair Maid of France.

Luxury............ Chostnut Tree.

Magnifieent beauty... Calla Athiopica.

Majesty............... Crown Imperial.

Make haste........... Dianthus.

Malevolenee ...........Lobclia.

Marriage .............. Ivy.

Maternal affeetion...... Cinquefoit.

Maternal love.........Moss.

Maternal tenderness ... Wood Sorvel.

Matrimony............ American Linden.

Matronly graee....... Cattleya.

Mature eharms........ Cattleya Pincli.

May you be happy.... Volkemenia.

Meanness........... Coscuta.

Meekness............ Birch.

Melaneholy ..........Dark Geranium.

Melancholy ........... Dead Leaves.

Mental beauty......... Clematis

Mental benuty..... . Kennedia. 
Mfessage ............ Iris.

Mildness............Mallozo.

Mirtb.............. Saffron Crocus.

Misanthropy........... Aconite (Wolfsbane).

Misanthropy.......... Fuller's Teazle.

Modest beauty........ Trillium Pictum.

Modest genius......... Creeping Cereus.

Modesty............. Viotet.

Modesty and purity... White Lity.

Momentary happiness. Virginian Spiderwort.

Mourning ........... Weeping Willow.

Musie................ Bundles of Reeds with their Panicles.

My best days are past. Colchicum, or Meadow

IIy regrets follow you Safron.

to the grave......... Asphodel.

Neatness ............ Bronm.

Negleeted beauty ..... Throatroort.

Never-eeasing remem.

branee.............. Everlasting.

Never despair........ Watcher by the Wayside.

No ................ Snapdragon.

Old age............ Tree of Life.

Only deserve my love. Campion Rose.

Painful reeo!leetions... Flos Adonis.

Painting..............Auricula.

Painting the lily........ Daphne Odora.

Passion ............. White Dittany.

I'aternal error......... Cardamine.

Fatienee............. Dock. Ox Eye.

Patriotism..........American Elm. 
Patriotism.......... Nasturtium.

Peaee............... Olive.

Perfeeted loveliness... White Camellia $J a$ -

Perica.

Perfidy............ Common Laurel, in

Pensire beanty........ Laburnum.

P'erplexity ........... Love in a Mist.

P'erseeution...........Checkered Fritillary

Perseveranee........... Swamp Magnolia.

Persuasion............... Althea Frutex.

Persuasion............... Syrian Mallow.

I'ertinaeity .......... Clotbur.

Pity .................... Pine, also Andromeda.

Pleasure and paiu..... Dog Rose.

Pleasure, lasting...... Everlasting Pea.

Pleasures of memory.. White Periwinkle.

Popular favor......... Cistus, ar Rock Rose.

Poverty ................. Evergreen Clematis.

Power.............. Imperial Montague.

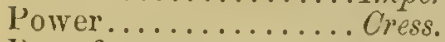

Pray for me.......... White Verbena.

Preeaution............. Golden Rod.

Predietion ............ Prophetic Marigold.

Pretension .............Spiked Willow Herb.

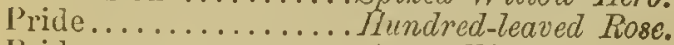

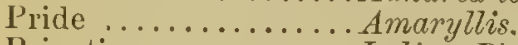

Privation ............. Indian Plum.

Privation .................

Profit.................. Cabbage.

Prohibition ............. Privet.

Prolifie .................. Tree.

Promptness ........... Ten-rveek Stock.

Prosperity........... Beech Tree.

Proteetion ............. Bearded Crepis. 
Prudenee ...........Mountain Ash.

Pure love............. Single Red Pink.

Pure and ardent love.. Double Red Pink.

Pure and lorely....... Red Rosebud.

Purity...............Star of Bethlehem.

Quarrel.............Broken Corn-straw.

Quicksightedness .....IIawkweed.

Ready armed.........Gladioli.

Reason .............. Goat's Riue.

Reeantation .......... Lotus Leaf.

Reeall .............Silver-leaved Geranium.

Reeoneiliation ........Fizbert.

Reconeiliation ........ Ilaze?.

Refinement.........Gardenia.

Refusal.............Striped Carnation.

Regard ............ Daffodil.

Regret............ Purple Verbena. Relief ............. Batm of Gilead.

Relieve my anxiety... Christmas Rose

Religious superstition. Aloe.

Religious superstition,

or faith........... Prssion Flower.

Religious enthusiasm. .Sehinus.

Remembranee........ Tísemary.

Remorse ............ Bramble.

Remorse .............. Raspberry.

Rendezvous ............ Chiekweed.

Reserve........................

Resistanee.......... Tremella iestoc.

Resolved to be notieed. Siphoeampylos.

Restoration.......... I'ersicaria.

Retaliation.......... Scoteh Thistle.

Return of halpiness... Lily of the Valley. 
Revenge............Birdsfoot Trefcil.

Reverie ............ Flowering Fern.

Reward of merit........ Bay Wreath.

Reward of virtue..... Garland of Roses.

Riehes............... Corn.

Rigor................ Lantana.

Rivalry............. hiocket.

Rudeness............ Clotbur.

Rudeness............. Tanthium.

Rural happiness....... Yellow Violet.

Rustie beauty.......... French Honeysuckie.

Rustie oraele.......... Dandelion.

Siadness............ Dead Leaves.

Siafety ............. Traveller's Joy.

Satire.............. Prickly Pear.

Seulpture........... Hoya.

Secret love............. Kellow Acacia.

Semblance............ Spitied Speedwell.

Sensitiveness ......... Mrimosa.

Sensuality........... Spanish Jasmine.

Separation........... Carolina Jasmine.

Severity.............Branch of Thorns.

S'hame............. Peony.

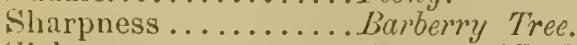

Siekness.............Anemone (Zephyr Flower).

silliness............. Fool's Parsley.

Simplieity...........American Sweetbrier.

Sineerity...........Garden Chervil.

Slighted love......... Tollow Chrmsanthemum. sinare.............. Catchfly. Iragon Plant.

Solitude.............Heath.

Sorrow............. Tew.

Sourness of temper... Barberry.

Spell................. Circas. 
Spleen .............. Fumitory.

Splendid beauty.......Amaryllis.

Splendor ..............Austurtium.

Sporting................ Fox-tail Grass.

Steadfast piety.........Wild Geranium.

Stoicism ............Box Tree.

Strength ................. Cedar. Fennel.

Stupidity............. Itorsestoe-leaf Geranium.

Submission........... Grass.

Submission........... Itarebell.

Suceess everywhere... Nemophila.

Success crown your

wishes............. Coronella.

Succor..............Juniper.

Sueh worth is rare.... Achimenes.

Sunbeaming eycs......Scarlet Lychnis.

Surprise $: \ldots \ldots \ldots \ldots$ Truffle.

Susceptibility ......... Wax Plant.

suspicion ........... Champignon.

Sympathy ........... Balm.

Sympatliy ............ Thrift.

Talent............ White Pink.

'T'ardiuess.............. Flax-leaved Golden-locks.

'Taste ................ Scarlet Fuschia.

'Tears................ Helenium.

T'emperanee ...........Azalea.

'Temptation............ Apple.

Thankfulness .........Agrimony.

The color of my fate... Coral Honcysuckile.

The heart's mystery... Crimson Polyanthus.

The perfection of fe-

male loveliness...... Justicia.

The witching soul of music............. Oats 
The rariety of your couversation delights me.......... Clariria.

There is no unalloyed good .............. Lapayenia Rosea.

Thoughts........... Pansy.

Thoughts of absent friends ........... Zinnia.

Thy frown will kill me. Currant. Thy smile I aspire to.. Daily hiose.

'lies.............. Tendrits of climbing Plants.

Timidity...........Amaryllis. Timidity ............... Marvel of Peru. Time.............. White I'oplar.

Tranquillity .......... Mudwort. Tranquillity ............ Stonecrop. Tranquillize my anxlety............. Christmas Rose. Transient beauty....... Night-blooming Cereus. Trausient impressions. Withered White Rose. Transport of joy...... Cape Jasmine. Treachery .............. Bitberry. T'rue love............. Forget-me-not. True friendship....... Oak-leaved Geranium. Truth ............... Bittersweet Nightshade. Truth ............. White Chrysanthemum.

Unanimity .........Plhlox.

Unbelief.............Judas Tree.

Uneeasing remembrance................merican Cudweed.

Unchanging friendship............... Arbor Titer.

Unconscious beauty.... Burgundy Rose. 
Unexpeeted meeting..Lemon Geranium.

Unfortunate attaehment ............. Mourning Bride.

Unfortunate love....... Scabious.

Union .............. Whole Straw.

Unity............ White and Red Rose to-

Unite agaiust a eomgether. mou foe.......... Scarlet Verbena.

Unpatronized merit... Red Primiose.

Uprightness .......... Imb rieata.

Uselessness........... Meadowsweet.

Utility................ Grass.

Variety ............ China Aster.

Variety ............................. Rose.

Viee................. Damnel (Ray Grass).

Vietory............... Palm.

Virtue...............Mirt.

Virtue, domestie...... Sage.

Volubility ...........Abecedary.

Voraeiousness ......... Lupine.

Vulgar minds............African llarigold.

War.............. York and Lancaster hose.

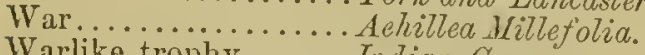

Warlike trophy........ Indian Cress.

Warmth of feeling.......Peppermint.

Watehfulness......... Dame Violet.

Weakness ............ Mlosehatel.

Weakness ............ Arusk Plant.

Weleome, fair stranger. Westeria.

Weleome to a stranger. Ameriean Starwort.

Widowhood.......... Sweet Seabious. 
Will you accompany

me to the East?..... Stephanotis.

Will you dance with

me?.............. Viscaria Oculata.

Wiu me and wear me.. Lady's Slipper.

Winning grace........ Cowslip.

Winter age............Guelder. Rose.

Wisdom .............. Blue Salvia.

Wit ................ Aleaworo Lychnis.

Wit ill-timed.......... Wild Sorrel.

Witchcraft...........Enchanter's Nightshade.

Worth beyond beauty. Sweet Elysium.

Worth sustained by

judicious and ten-

der affectiou........ Pink Convolvulus.

Worldliness, self-

secking............ Clianthus.

Worthy of all praise... Fennel.

You are cold .......... Hortensia.

You are my divinity... American Cowslip.

You are perfect....... Pine Apple.

You are radiant with

charms ...........Ranunculus.

You are rich in at-

traction .......... Garden Ranunculus.

You are the quecn of

coquettes......... Queen's Rocket.

You are charming..... Leschenuultia Splendens.

You have no claims... Pasque Flower.

Y'ou have many lovers. Chorozema Varium.

You plcase all........ Branch of Currants.

You are too bold...... Diplademia Crassinoda.

You will be my death. Hemlock. 
Your charms are engraven on my heart. Spindle Tiree.

Your looks freeze me. . Ice Plant.

Your preseuce softens my pain............ Milkvetch.

Your purity equals your loveliness...... Orange Blossoms.

Your qualities, like your charms, are unequalled .........Peach.

Your qualitics surpass your charms........Mignonette.

Your temper is too hasty.............. Grammanthes Chloraflora.

Youthful innocence... Thite Litac.

Youthful love.........Red Catchfly.

Your whims are unbearable............Monarda Amplexicaulis.

Zealousness ..........Elder.

Zest...............Lemon. 


\section{MODIFICATIONS OF THE FLOWER IANGUAGE.}

If a llower be given reversed, its original signifieation is understood to be eontradieted, and the opposite meaning to be implied.

A rosebud divested of its thorns, but retaining its leaves, eonveys the sentiment, "I fear no longer; I hope; " thorns signifying tears, and leaves hopes.

Stripped of leaves and thorns, the bud signi. fies, "There is nothing to lope or fear."

The expression of flowel's is also raried by ehanging their positions. Plaee a marigold on the head, and it signifies "Mental anguish;" on the bosom, "Indifferenee."

When a flower is given, the pronoun $I$ is understood by bending it to the right hand; thou, by inelining it to the left.

"Yes" is implied by touehing the flower given with the lips.

"No," by pincling oft" a petal, and easting it ¿way.

"I am," is expressed by a laurel-leaf twisted round the bouquet.

"I have," by an ivy-leaf folded together.

"I ofler you," by a leaf of the Virginian Creeper. 


\section{BOUQUETS AS EXAMPLES.}

\section{SPRING.}

1.

May maternal love protect your early youth in innocence and joy!

Flowers needed.

Moss..............Maternal Love.

Bcarded Crepis....... Protect.

Primroses ........... Farly youth.

Daisy ................ Innocence.

Wood Sorrel..........Joy.

\section{SUMMER.}

2.

Your humility and amiability have won my love.

Flowers needed.

Broom ..............Iumility.

White Jasnine.........Amiability.

Myrtle............Love.

3.

Let the bonds of marriage unite us.

Flowers needed.

Blue Convolvulus..... Bonds. 


\section{Ivy............... Marriage.}

A few whole straws... Unite us.

\section{A Farewell.}

Farewell! give me your good wishes. Forget me not.

\section{Flowers needed.}

Sprig of Spruee Fir...Farewell.

Siveet Basil........... Give me your good wishes. Forget-Me-sot......... Forget me not.

5.

Your patriotism, eourage, and fidelity merit everlasting remembranee.

Flowers needed.

Nasturtium ..........Patriotism.

Oak Leaves............. Courage.

Heliotrope............. Fidelity.

Everlasting, or Im-

mortelles .......... Everlasting remembrance.

6.

$\Lambda$ Red Rose.......... I love you.

\%.

An Impertinence.

Your insineerity and avariee make me hate you.

Flowers needed.

Cherry Blossom, or

Foxglore.......... Insincerity. 
Scarlet Auricula...... Avarice.

Turk's Cap............ttatred.

8.

A Warning.

Beware of deceit. Danger is near. Depart.

Flowers needed.

Oleander ............ Beware.

White Flytrap......... Deceit.

Rhododendron........ Danger is near.

Sweet Pea............. Depart.

\section{9. \\ A RebUKe.}

Your frivolity and malevolenee will cause you to be forsaken by all.

Flowers needed.

London Pride......... Frivolity.

Lobelia................Malevolence.

Laburnum............Forsaken.

\section{AUTUMNAL.}

10.

Be assured of my sympathy. Mas you find consolation!

Flower's needed.

Thrift............. Be assured of miy symRed Poppy.......... Cor solution. 


\section{WINTER.}

11.

By foresight you will surmount your difficulties.

Flowers needed.

Holly............. Foresight.

Jistletoe.......... You will sumnount your Tifficulties 





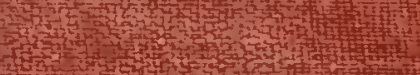

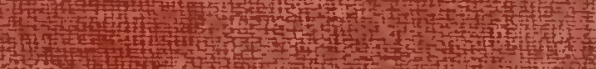

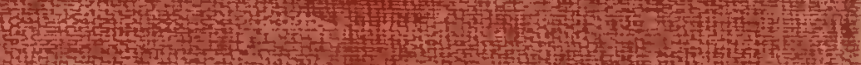

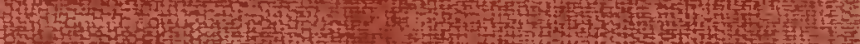
$4 h-1$ mon

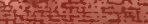

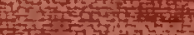
$x \rightarrow \frac{1}{2}+x^{2}$

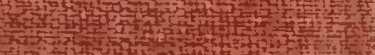

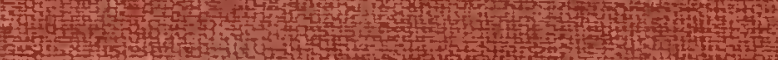

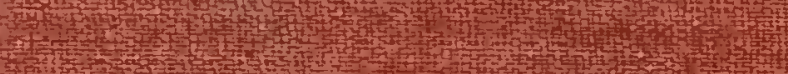

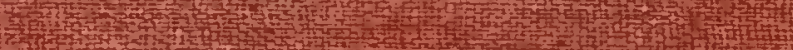

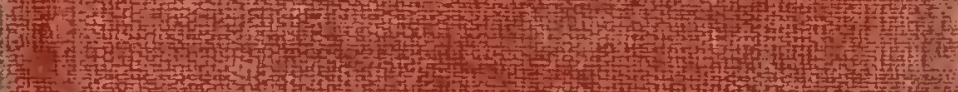
3.

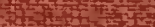

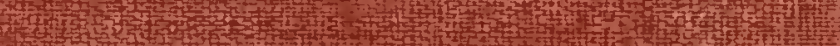

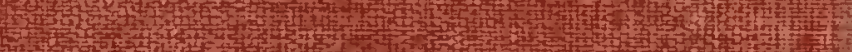

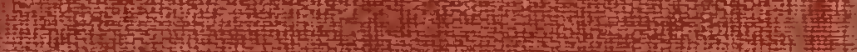

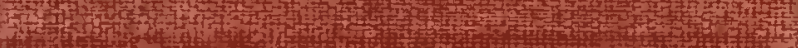

